\title{
PERAN PEMBELAJARAN BAHASA DAN SASTRA INDONESIA DALAM PEMBENTUKAN KARAKTER PESERTA DIDIK
}

\author{
Oleh \\ Abdul Rahman \\ Program Studi Pendidikan Bahasa dan Sastra Indonesia \\ Program Pascasarjana \\ Universitas Negeri Medan
}

\begin{abstract}
Indonesia has an education figure that greatness is not inferior to other world education figures i.e. Ki Hajar Dewantara. He explained that education is an effort in increasing the growth of manners (inner strength, character, mind, and intellectualism) from the body of the students, so the live of the students suit their world. Learning is defined by Knowles as a way of organizing learners to achieve the goal. Manners operationally is a positive behavior that is done through the custom that is formed into a person's character/learners. Based on these two definitions appears that education, learning, character/characters is a unity that cannot be separated with each other. Positive behaviors that must be drilled to learners consists of many aspects and one of them is how to speak. Thus, training the speech containing positive behavior is mandatory for language teacher (Indonesian Language). Any language skills cannot be trained separately between one's skills with other language skills. As a professional teacher, arranging strategies for Indonesian language teacher which are always associated with character education will no longer be a burden. Literature is a picture of human life. Literature becomes right media in imparting a positive character for learners. Through the Indonesia language teacher professionalism will form a younger generation who have lofty manners or strong character.
\end{abstract}

Keywords: learning, language and literature, characters.

Kata kunci: pembelajaran, bahasa dan sastra, karakter.

\section{A. Pendahuluan}

Indonesia memerlukan sumber daya manusia dalam jumlah dan mutu yang memadai sebagai pendukung utama dalam pembangunan. Untuk memenuhi sumber daya manusia tersebut, pendidikan memiliki peran yang sangat penting dalam mengembangkan sumber daya manusia tersebut. Sistem Pendidikan Nasional, menyebutkan bahwa pendidikan nasional berfungsi mengembangkan kemampuan dan membentuk karakter serta peradaban bangsa yang bermartabat dalam rangka mencerdaskan kehidupan bangsa. Pendidikan nasional bertujuan untuk berkembangnya potensi peserta didik agar menjadi manusia yang 
beriman dan bertakwa kepada Tuhan Yang Maha Esa, berakhlak mulia, sehat, berilmu, cakap, kreatif, mandiri, dan menjadi warga negara yang demokratis serta bertanggung jawab.

Berdasarkan fungsi dan tujuan pendidikan nasional, jelas bahwa pendidikan di setiap jenjang, SMA, SMP sampai SD harus diselenggarakan secara sistematis guna mencapai tujuan tersebut. Hal tersebut berkaitan dengan pembentukan karakter peserta didik sehingga mampu bersaing, beretika, bermoral, sopan santun dan berinteraksi dengan masyarakat. kesuksesan seseorang tidak ditentukan semata-mata oleh pengetahuan dan kemampuan teknis (hard skill) saja, tetapi lebih oleh kemampuan mengelola diri dan orang lain (soft skill). Penelitian ini mengungkapkan, kesuksesan hanya ditentukan sekitar 20 persen oleh hard skill dan sisanya 80 persen oleh soft skill. Bahkan orang-orang tersukses di dunia bisa berhasil dikarenakan lebih banyak didukung kemampuan soft skill daripada hard skill. Hal ini mengisyaratkan bahwa mutu pendidikan karakter peserta didik sangat penting untuk ditingkatkan.

Kondisi masyarakat dewasa ini sangat memprihatinkan. Perkelahian, pembunuhan, kesenjangan sosial, ketidakadilan, perampokan, korupsi, pelecehan seksual, penipuan, fitnah terjadi di mana-mana. Hal itu dapat diketahui lewat berbagai media cetak atau elektronik, seperti surat kabar, televisi atau internet. Bahkan, tidak jarang kondisi seperti itu dapat disaksikan secara langsung di tengah masyarakat. Selain itu, merebaknya sikap hidup yang buruk, melembaga budaya kekerasan, atau merakyat bahasa ekonomi dan politik, disadari atau tidak, telah ikut melemahkan karakter anak-anak bangsa sehingga menjadikan nilai-nilai luhur dan kearifan sikap hidup mati suri. Anak-anak sekarang mudah sekali melontarkan bahasa oral dan bahasa tubuh yang cenderung tereduksi oleh gaya ungkap yang kasar dan vulgar.

Dewasa ini sering kita membahas pendidikan yang berorientasi pada pembentukan karakter. Hal tersebut dapat diwujudkan melalui pengoptimalan peran bahasa dan sastra, oleh karena itu sekurangnya ada dua perspektif yang mengemuka. Pertama, dari sudut pandang paradigma pendidikan bahasa dan sastra. Pendidikan bahasa dan sastra dirasakan memang sangat penting karena ketika seorang pendidik memberikan pengajaran kepada anak-anak didiknya, ia harus bisa menggunakan bahasa dengan baik dan benar. Apabila seorang pendidik mengunakan bahasa yang kurang baik, maka akan dicontoh oleh anak-anak didiknya dan itu akan mengakibatkan peran bahasa dalam dunia pendidikan menjadi kurang berkualitas. Kedua, dari perspektif hubungan antara pendidikan bahasa, sastra, dan pembentukan karakter. Untuk membentuk karakter bangsa ini, sastra diperlakukan sebagai salah satu media atau sarana pendidikan kejiwaan. 
Hal itu cukup beralasan sebab sastra mengandung nilai etika dan moral yang berkaitan dengan hidup dan kehidupan manusia. Sastra tidak hanya berbicara tentang diri sendiri (psikologis), tetapi juga berkaitan dengan Tuhan (religiusitas), alam semesta (romantik), dan juga masyarakatnya (sosiologis). Sastra mampu mengungkap banyak hal dari berbagai segi, salah satunya pemebentukan karakter yakni cara berpikir dan berperilaku yang menjadi ciri khas setiap individu untuk hidup dan bekerja sama, baik dalam lingkup keluarga, masyarakat, bangsa, maupun negara.

Berdasarkan latar belakang di atas, rumusan masalah dalam penulisan ini adalah (1) Bagaimana pembelajaran bahasa dan sastra Indonesia? (2) Apakah pendidikan karakter itu? (3) Bagaimana memberdayakan sastra dalam pembentukan pendidikan karakter bagi peserta didik?

\section{B. Kajian Pustaka}

\section{Pembelajaran Bahasa Dan Sastra Indonesia}

Istilah pembelajaran sering terdengar dalam kajian pendidikan di sekolah saat ini. Istilah ini merupakan pengembangan istilah dari "Proses Belajar Mengajar" (PBM). Dalam istilah PBM makna yang familiar bagi guru-guru saat ini adalah guru melakukan pengajaran dalam berbagai materi ajar kepada peserta didik. Sedangkan istilah pembelajaran saat ini menjadi aktual, dimaknai sebagai proses interaksi peserta didik dengan lingkungan belajarnya. Dalam proses ini anak menjadi objek sekaligus subjek belajar. Guru dan lingkungan belajar lainnya menjadi kondisi penting yang menyertai proses pembelajaran.

Pembelajaran dalam pendidikan karakter didefinisikan sebagai pembelajaran yang mengarah pada penguatan dan pengembangan perilaku anak secara utuh yang didasarkan atau dirujuk pada suatu nilai. Penguatan adalah upaya untuk melapisi suatu perilaku anak sehingga kuat. Pengembangan perilaku adalah proses adaptasi perilaku anak terhadap situasi dan kondisi baru yang dihadapi berdasarkan pengalaman baru. Kegiatan penguatan dan pengembangan didasarkan pada suatu nilai yang dirujuk. Artinya proses pendidikan karakter adalah proses yang terjadi karena didesain secara sadar, bukan suatu kebetulan.

Menurut Woolfork pembelajaran berlaku apabila sesuatu pengalaman secara relatifnya menghasilkan perubahan kekal dalam pengetahuan dan tingkah laku. Pembelajaran menurut Knowles adalah cara pengorganisasian peserta didik untuk mencapai tujuan pendidikan. Pendidikan karakter secara terintergrasi di dalam proses pembelajaran adalah pengenalan nilai-nilai, fasilitasi diperolehnya kesadaran akan pentingnya nilai-nilai, dan penginternalisasian nilainilai kedalam tingkah laku peserta didik sehari-sehari melalui proses 
pembelajaran baik yang berlangsung di dalam maupan di luar kelas pada semua mata pelajaran, selain untuk menjadikan peserta didik menguasai materi yang ditargetkan, juga dirancang dan dilakukan untuk menjadikan peserta didik mengenal, menyadari/peduli, dan menginternalisasi nilai-nilai dan menjadikannnya perilaku.

Menurut para ahli, Plato mengemukakan bahwa bahasa pada dasarnya adalah pernyataan pikiran seseorang dengan perantaraan onomata (nama benda atau sesuatu) dan rhemata (ucapan) yang merupakan cermin dari ide seseorang dalam arus udara lewat mulut. Carrol berpendapat bahwa bahasa adalah sebuah sistem berstruktural mengenai bunyi dan urutan bunyi bahasa yang sifatnya manasuka, yang digunakan, atau yang dapat digunakan dalam komunikasi antar individu oleh sekelompok manusia dan yang secara agak tuntas memberi nama kepada benda-benda, peristiwa-peristiwa dan prosesproses dalam lingkungan hidup manusia. Sudaryono mengemukakan bahwa bahasa adalah sarana komunikasi yang efektif walaupun tidak sempurna sehingga ketidaksempurnaan bahasa sebagai sarana komunikasi menjadi salah satu sumber terjadinya kesalahpahaman.

Dapat disimpulkan bahwa bahasa alat komunikasi antara anggota masyarakat berupa simbol bunyi yang dihasilkan oleh alat ucap manusia. Bahasa memberikan kemungkinan yang jauh lebih luas dan kompleks daripada yang dapat diperoleh dengan mempergunakan media. Bahasa haruslah merupakan bunyi yang dihasilkan oleh alat ucap manusia. Bukan sembarang bunyi karena bunyi itu sendiri haruslah merupakan simbol atau perlambangan.

Sebagai cerminan keadaan sosial budaya bangsa haruslah diwariskan kepada generasi mudanya. Aminuddin (2002:31) mengemukakan bahwa sastra memiliki potensi yang besar untuk membawa masyarakat ke arah perubahan, termasuk perubahan karakter. Selain mengandung keindahan, sastra juga memiliki nilai manfaat bagi pembaca. Segi kemanfaatan muncul karena penciptaan sastra berangkat dari kenyataan sehingga lahirlah suatu paradigma bahwa sastra yang baik menciptakan kembali rasa kehidupan. Sebagai wujud untuk menyampaikan atau menginjeksikan pendidikan karakter dalam sastra kepada peserta didik ada beberapa upaya yang bisa dilakukan oleh pendidik.

Pendidik mengungkapkan nilai-nilai dalam mata pelajaran bahasa dan sastra Indonesia dengan pengintegrasian langsung nilai-nilai karakter yang menjadi bagian terpadu dari mata pelajaran tersebut. Pendidik bisa menggunakan perbandingan cerita pendek berdasarkan kehidupan atau kejadian-kejadian dalam hidup para peserta didik kemudian mengubah halhal yang bersifat negatif dalam cerita pendek tersebut menjadi nilai positif. Dengan ini peserta didik mampu mengambil secara langsung nilai-nilai pendidikan karakter yang tersirat dan tersurat dalam tugas yang diberikan pendidik tadi karena merupakan bagain dari 
kehidupan peserta didik itu sendiri. Atau bisa juga menggunakan cerita untuk memunculkan nilai-nilai karakter dengan menceritakan kisah hidup orang-orang besar. Dengan kisah nyata yang dialami orang-orang besar dan terkenal bisa menjadikan peserta didik akan terpikat dan mengidolakan serta pastunya ingin menjadi seperti idolanya tersebut.

Puisi (lagu) memberikan efek yang sangat dalam bagi pendengarnya. Bahkan kabar terkini yang telah kita ketahui bersama, bayi dalam kandungan pun bisa dipengaruhi dengan lagu yang diputar dekat dengan perut ibunya. Dengan dasar ini pendidik bisa menggunakan lagu-lagu dan musik (musikalisasi puisi) untuk mengintegrasikan nilai-nilai karakter dalam benak peserta didik.

Pendidik bisa juga menggunakan drama sebagai media untuk melukiskan kejadiankejadian yang berisikan nilai-nilai karakter. Sehingga secara audio visual serta aplikasi langsung (pementasan drama) menjadikan peserta didik lebih mudah untuk memahami dan menyerap nilai-nilai karakter tersebut. Selain itu tugas-tugas yang bisa dikerjakan dirumah dapat mengambil contoh tentang apa yang dilihat peserta didik di televisi kemudian pendidik akan menjelaskan sekaligus meluruskan nilai-nilai apa saja yang ada dalam film di televisi tersebut. Ini akan lebih menggoreskan dalam-dalam nilai-nilai pendidikan karakter yang didapat di benak peserta didik.

Menggunakan novel sebagai media untuk mengungkapkan nilai-nilai atau norma-norma dalam masyarakat melalui diskusi dan brainstorming pun bisa digunakan oleh pendidik. Novel banyak memberikan kisah-kisah yang mampu menjadikan pembacanya berimajinasi dan masuk dalam cerita novel tersebut.

\section{Pendidikan Karakter}

Pendidikan karakter mulai didengungkan di era Mendikbud Muhammad Nuh. Menurutnya pendidikan di Indonesia mulai melupakan pembentukan karakter siswa. Atas dasar pemikiran itulah pendidikan saat ini harus memuat pendidikan karakter. Koesuma dalam artikelnya menyatakan tujuan pendidikan adalah untuk pembentukan karakter yang terwujud sdalam kesatuan esensial si subjek dengan perilakun dan sikap hidup yang dimilikinya. Karakter menjadi identitas yang mengatasi pengalaman kontingen yang selalu berubah. Dari kematangan karakter inilah, kualitas seseorang secara pribadi mampu diukur. Bahasa mencerminkan bangsa. Itulah kira-kira gambaran bagaimana hubungan bahasa dengan pendidikan karakter. Bahasa yang notabene alat komunikasi mempunyai dampak yang besar terhadap perilaku manusia. Hal tersebutlah yang meyakini setiap tuturan yang diucapkan manusia mempunyai karakter tersendiri. 
Muslich (2011:12) mengemukakan bahwa pendidikan adalah proses internalisiasi budaya ke dalam diri seseorang dan masyarakat sehingga membuat orang dan masyarakat menjadi beradab. Pendidikan bukan hanya merupakan sarana tranfer ilmu pengetahuan (transfer of knowledge) saja tetapi lebih luas lagi, yaitu sebagai sarana membudayaan dan penyaluran nilai (enkluturasi dan sosialisasi). Anak harus mendapatkan pendidikan yang menyentuh dimensi dasar kemanusiaan.

"Pendidikan adalah upaya untuk memajukan budi pekerti (kekuatan batin, karakter), dan jasmani anak didik" (Ki Hajar Dewantara) Dewasa ini sering terdengar banyak kalangan membicarakan pendidikan karakter. Kemerosotan sisi -sisi kehidupan bermasyarakat, berbangsa dan bernegara tampaknya dijadikan sebab begitu pentingnya hal tersebut kembali dibicarakan.

Aunillah (2011:19) mengemukakan bahwa pendidikan karakter adalah sebuah sistem yang menanamkan nilai-nilai karakter pada peserta didik, yang mengandung komponen pengetahuan, kesadaran individu, tekad, serta adanya kemauan dan tindakan untuk melaksanakan nilai-nilai, baik terhadap Tuhan Yang Maha Esa, diri sendiri, sesama manusia, lingkungan,maupun bangsa sehingga akan terwujudnya insan kamil

Dengan demikian, pendidikan karakter dapat dimaknai sebagai suatu proses internalisasikan sifat-sifat utama yang menjadi ciri khusus dalam suatu masyarakat ke dalam diri peserta didik sehingga dapat tumbuh dan berkembang menjadi manusia dewasa sesuai dengan nilai-nilai budaya masyarakat setempat.

Dalam grand desain pendidikan karakter adanya proses pembudayaan dan pemberdayaan nilai-nilai luhur dalam lingkungan satuan pendidikan (sekolah), lingkungan keluarga, dan lingkungan masyarakat. Nilai-nilai luhur ini berasal dari teori-teori pendidikan, psikologi pendidikan, nilai-nilai sosial budaya, ajaran agama, Pancasila dan UUD 1945, dan UU No. 20 Tahun 2003 tentang Sistem Pendidikan Nasional, serta pengalaman terbaik dan praktik nyata dalam kehidupan sehari-hari. Proses pembudayaan dan pemberdayaan nilai-nilai luhur ini juga perlu didukung oleh komitmen dan kebijakan pemangku kepentingan serta pihak-pihak terkait lainnya termasuk dukungan sarana dan prasarana yang diperlukan.

\section{Implementasi Sastra dalam Pembentukan Pendidikan Karakter Bagi Peserta Didik}

Sastra bersifat indah dan bermanfaat. Dari aspek gubahan, sastra disusun dalam bentuk yang apik dan menarik sehingga orang senang membaca, mendengar, melihat, dan menikmatinya. Sementara itu, dari aspek isi ternyata karya sastra sangat bermanfaat. 
Didalamnya terdapat nilai-nilai pendidikan moral yang berguna untuk menanamkan pendidikan karakter. Berkaitan dengan karakter, Saryono (dalam Septiningsih, 2011:2) mengemukakan bahwa karya sastra yang dapat dijadikan sarana untuk membentuk karakter bangsa, antara lain:

1) Karya sastra yang mengandung nilai estetika adalah sastra yang mengandung nilai keindahan, keelokan, kebagusan, kenikmatan, dan keterpanaan yang dimungkinkan oleh segala unsur yang terdapat di dalam karya sastra. Dengan nilai estetika yang termuat dalam sastra tersebut, diharapkan karakter bangsa yang terbentuk adalah insan Indonesia yang memiliki rasa keindahan, ketampanan, dan keanggunan dalam berpikir, berkata, dan berperilaku sehari-hari.

2) Karya sastra yang mengandung nilai humanis adalah sastra yang mengandung nilaikemanusiaan, menjunjung harkat dan martabat manusia, serta menggambarkan situasidan kondisi manusia dalam menghadapi berbagai masalah. Kehadiran karya sastrasemacam itu diharapkan dapat membentuk kearifan budaya bangsa Indonesia yangmemiliki rasa perikemanusiaan yang adil, beradab, dan bermartabat.

3) Karya sastra yang mengandung nilai etika dan moral adalah karya sastra yang mengacu pada pengalaman manusia dalam bersikap dan bertindak, melaksanakan yang benar danyang salah, serta bagaima na seharusnya kewajiban dan tanggung jawab manusia dilakukan. Norma etis dan moral tersebut dapat dijadikan wahana pembentukan karakter bangsa yang lebih mengutamakan etika dan moral dalam bersikap dan bertindak seharihari.

4) Sastra religius adalah sastra yang menyajikan pengalaman spiritual. Semua sastra padaawalnya digunakan sebagai sarana berpikir dan berzikir manusia akan kekuasaan,keagungan, kebijaksanaan, dan keadilan Tuhan yang Maha Esa Kehadiran sastra tersebutdapat membentuk karakter bangsa Indonesia sebagai insan yang religius, penuh rasa berbakti, beriman, dan bertakwa kepada Tuhan yang Maha Esa dalam kehidupan sehari-hari.

Berkaitan dengan karakter, Saryono (2010: 59) menegaskan bahwa genre sastra yang dapat dijadikan sarana untuk membentuk karakter bangsa, antara lain, genre sastra yang mengandung nilai atau aspek (1) literer-estetis, (2) humanistis, (3) etis dan moral, dan (4) religius-sufistisprofetis. Keempat nilai sastra tersebut dipandang mampu mengoptimalkan peran sastra dalam membangun generasi yang berkarakter.

Sasaran pembentukan karakater kepada peserta didik dilakukan baik di tingkat dasar, menengah dan perguruan tinggi sehingga terbentuklah generasi yang religius, jujur, toleransi, 
disiplin, kerja keras, kreatif, mandiri, demokratis, rasa ingin tahu, semangat kebangsaan, cinta tanah air, menghargai prestasi, bersahabat/komunikatif, cinta damai, gemar membaca, peduli lingkungan, peduli sosial, dan tanggung jawab.

\section{Simpulan}

Sastra sebagai media untuk pengintegrasian, penyampaian pendidikan karakter kepada peserta didik, penanaman nilai-nilai yang baik mampu menjadi salah satu metode untuk menuju pendidikan yang lebih baik di tengah kebangkrutan moral bangsa, maraknya tindak kekerasan, inkoherensi politisi atas retorika politik, yang tengah menjalar dan menjangkiti bangsa ini. Pengajaran sastra mampu dijadikan sebagai pintu masuk dalam penanaman nilainilai moral seperti kejujuran, pengorbanan, demokrasi, santun dan sebagainya.

Berbagai upaya yang bisa dilakukan pendidik melalui pembelajaran sastra yang disertakan pula pendidikan karakter di dalam penyampaiannya, baik melalui puisi, lagu, cerpen, novel, drama, dan cerita rakyat nampaknya akan mampu membawa pendidikan karakter untuk masuk ke dalam jiwa peserta didik dan secara utuh.

Berkenaan dengan materi yang mengandung nilai-nilai pendidikan karakter dalam pembelajaran bahasa Indonesia adalah mendengarkan, membaca, bercakap-cakap, mengarang dan menulis, Secara umum nilai-nilai yang terdapat pada materi-materi pembelajaran bahasa Indonesia adalah kejujuran, keberanian, rasional, kreatifitas, menghargai, kerja keras, sopan santun dan sebagainya. Terselenggaranya pendidikan di tiga lingkungan sangat memungkinkan penggunaan bahasa memiliki pengaruh yang besar. Dari cerminan tersebut perlunya pengajaran bahasa dan kaitannya dengan pendidikan dinilai mampu memberikan hal positif dalam pembentukan karakter seseorang melalui pendidikan berbasis karakter. Mempelajari dan mengembangkan bahasa dalam pendidikan sangatlah perlu ditingkatkan. Oleh sebab itu kita sebagai pemerhati pendidikaan mempunyai peran penting dalam menanamkan nilai-nilai positif serta pembentukan karakter seseorang melalui bahasa yang baik.

\section{DAFTAR PUSTAKA}

Aminuddin. 2002. Pengantar Apresiasi Karya Sastra. Bandung: Sinar Baru Algasindo. Aqib, Zainal dan Sujak. 2011. Panduan dan Aplikasi Pendidikan Karakter untuk Siswa Sekolah.Bandung: Yrama Widya. 
Aunillah, Nurla Isna. 2011. Pendidikan Karakter di Sekolah. Yogyakarta: Laksana.

Depdiknas. 2003. UU No. 20 tahun 2000 Sistem Pendidikan Nasional. www.depdiknas.go.id.

Dharma, Kesuma dkk. 2011. Pendidikan Karakter Kajian Teori dan Praktek di Sekolah. Bandung: PT Remaja Rosdakarya.

Doni, Koesoema A. 2010. Pendidikan Karakter: Strategi Mendidik Anak di Zaman Global. Jakarta: Grasindo.

Ihsan. Fuad. 2008. Dasar Dasar Kependidikan. Jakarta: Rineka Cipta.

Keraf, Gorys. 1997. Komposisi: Sebuah Pengantar Kemahiran Bahasa. Ende-Flores: Nusa Indah.

Lickona, Thomas. 2012. Educating For Character: Mendidik untuk Membentuk Karakter. Jakarta: Bumi Aksara.

Mulyasa, E. 2011. Manajemen Pendidikan Karakter. Jakarta: PT Bumi Aksara.

Muslich, Masnur. 2011. Pendidikan Karaktrer: Menjawab Tantangan Krisis Multidimensional. Jakarta: PT Bumi Aksara.

Nababan, Sri Subakto. 1992. Metodologi Pengajaran Bahasa. Jakarta: PT Gramedia.

Samani. Muchlas dan Hariyanto. 2011. “Konsep dan Model” Pendidikan Karakter. Bandung: PT. Remaja Rosdakarya.

Saryono, Djoko. 2010. Dasar Apresiasi Sastra. Yogyakarta: Elmatera Publishing. 


\title{
Oleh :
}

\section{Aprina Sirait}

\section{Jurusan Pendidikan Bahasa dan Sastra Indonesia \\ Pascasarjana Universitas Negeri Medan}

\begin{abstract}
ABSTRAK
Pencapaian hasil pembelajaran yang bermutu tersebut adalah proses pembelajaran yang bermutu dan stabil agar tercapai hasil belajar yang bermutu, tepat dan sesuai harapan. Dalam proses pembelajaran ini memang tetap juga dapat terjadi berbagai macam masalah apakah karena faktor pendidik,dan faktor masalah terjadi kurikulum.

Melalui penggunaan bahan ajar yang mengandung kearifan lokal dan metode pembelajaran berorientasi tindakan dalam kegiatan belajar mengajar diharapkan dialog antarbudaya akan terbangun. Hal itulah yang dapat menstimulasi pembelajar untuk berkonfrontasi secara kritis dengan budaya asing dan dirinya sendiri. Dan pada akhirnya mereka akan mampu melihat dan merasakan bahwa di antara budaya asing dan budayanya sendiri terdapat kesamaan atau kemiripan.
\end{abstract}

Kata Kunci: Pembelajaran, Teks drama, Kearifan Lokal 


\section{A. PENDAhuluan}

Proses belajar mengajar merupakan interaksi yang dilakukan guru dengan siswa dalam situasi-situasi pendidikan untuk mencapai tujuan yang ditetapkan. Proses belajar-mengajar dipengaruhi perkembangan zaman yang terus bergulir dan kadang tidak stabilnya dunia pendidikan dan pembelajarannya akan sangat merugikan, membuang-buang energi dan waktu dengan sangat sia-sia. Pendidikan atau proses pembelajaran bermutu adalah salah satu jalan penyelamat mencapai keberhasilan. Pencapaian hasil pembelajaran yang bermutu tersebut adalah proses pembelajaran yang bermutu dan stabil agar tercapai hasil belajar yang bermutu, tepat dan sesuai harapan. Dalam proses pembelajaran ini memang tetap juga dapat terjadi berbagai macam masalah apakah karena faktor pendidik,dan faktor masalah terjadi kurikulum. Salah satu masalah utama adalah kian kaburnya fungsi dan hakikat pembelajaran di mana peran seorang guru dan siswa telah dikaburkan, guru yang belajar sedangkan siswa hanya sebagai penonton dan pendengar. Perlu perbaikan dalam pembelajaran yang kabur selama ini yaitu restorasi pembelajaran yang berpusat pada siswa.

Keterampilan menulis merupakan salah satu komponen berbahasa yang sangat penting diajarkan ketika anak berajak usia dini. Hal ini dapat dijadikan bekal untuk jenjang sekolah yang lebih tinggi, dan berfungsi melatih siswa di dalam menyampaikan atau mengungkapkan buah pikirannya secara teratur, baik berbentuk kalimat-kalimat maupun berupa karangan.

Menulis merupakan suatu kegiatan komunikasi berupa penyampaian pesan (informasi) secara tertulis kepada pihak lain dengan menggunakan bahasa tulis sebagai alat atau medianya. Aktivitas menulis melibatkan beberapa unsur, yaitu penulis sebagai penyampaian pesan, isi tulisan, saluran atau media, dan pembaca. Menulis juga merupakan sebuah proses kreaktif menuangkan gagasan dalam bentuk bahasa tulis dalam tujuan : Memberitahukan dan menyakinkan. Kegiatan menulis ialah suatu proses, yaitu proses penulisan.

Dalam dunia pendidikan, pendidikan tetap mendapat perhatian yang serius dari pemerintah dan masyarakat, baik mengenai kualitas maupun kuantitas. Melalui peningkatan kualitas dan kuantitas pendidikan, akan dapat mempelancar tercapainya tujuan dalam pembelajaran bahasa Indonesia. Hal ini harus diterapkan dan harus dipandu karena kurangnya minat dan pengetahuan siswa dalam menulis. 
Adapun masalah keterampilan berbahasa yang menjadi fokus penelitian bahasa mencakup keterampilan membaca, menulis, berbicara dan menyimak. Keempat cakupan keterampilan berbahasa tersebut bukanlah satu aspek yang terpisah-pisah melainkan saling berkaitan satu dengan yang lainnya, yaitu membaca berkaitan erat dengan menulis atau sebaliknya, berbicara berkaitan erat dengan menyimak atau sebaliknya. Oleh sebab itu, pengajaran keterampilan berbahasa membutuhkan sebuah pengajaran yang kompleks, yang tidak hanya berdasarkan satu aspek keterampilan berbahasa saja.

Jika kearifan lokal digunakan sebagai acuan pengembangan pendidikan, pendidikan bukan saja akan menghasilkan kemajuan di bidang penguasaan ilmu pengetahuan dan teknologi melainkan juga menjadi wahana pelestarian budaya dan identitas bangsa (Subagia \& Wiratama dalam Suastra, 2005: 88). Berkaitan dengan pengintregasian budaya lokal ke dalam pembelajaran, hasil penelitian yang dilakukan oleh Jegede dan Aikenhead (dalam Suastra,2005) menegaskan bahwa keberhasilan proses pembelajaran di sekolah sangat dipengaruhi oleh latar belakang budaya yang dimiliki siswa atau masyarakat sekolah tersebut berada.

Pengintegrasian budaya dalam pembelajaran di sekolah dapat berupa kearifan lokal atau local wisdom. Pengintegrasian kearifan lokal dalam pembelajaran bahasa Indonesia salah satunya menulis teks drama merupakan suatu inovasi cemerlang.

Menulis naskah drama termasuk dalam bagian keterampilan berbahasa pada bidang menulis, kemampuan menulis naskah drama penting dimiliki oleh siswa kelas XI SMA karena hal itu termasuk dalam standar kompetensi yang terdapat dalam kurikulum pendidikan, selain itu alasan siswa dalam mempelajari ini adalah supaya mereka memiliki deskripsi perilaku manusia melalui konflik yang sesuai dengan gaya bahasa yang diperankan. Namun, kenyataan yang terjadi di lapangan kemampuan siswa dalam menulis teks naskah drama masih rendah, kurangnya kemampuan siswa dalam menulis naskah drama. Kenyataan ini terjadi dikarenakan kurangnya motivasi siswa untuk aktif dalam pembelajaran, kurangnya kesadaran siswa akan pentingnya pengetahuan.

\section{B. KAJIAN TEORETIS}

Kerangka teoritis merupakan pendukung suatu penelitian, karena dalam landasan teoritis diuraikan teori-teori yang berhubungan pendapat para ahli yang mempunyai hubungan dengan 
variabel peneliti. Sugiyono (2012:53) mengatakan "Suatu teori akan memperoleh arti yang penting bila ia lebih banyak dapat melukiskan, menerangkan, dan meramalkan yang ada ". Landasan teori dimuat untuk memperkuat pendapat peneliti bahwa penelitian yang dilaksanakan memiliki landasan teori.

Unsur-unsur penting dalam penulisan Naskah Drama yaitu :

\section{Tokoh}

Tokoh adalah orang-orang yang berperan dalam suatu drama. Berdasarkan perannya terhadap jalan cerita, tokoh bisa dibedakan menjadi tiga.
a. Tokoh Protagonis, yaitu tokoh yang mendukung cerita
b. Tokoh Antagonis, yaitu tokoh penentang cerita
c. Tokoh Tritagonis, yiatu tokoh pembantu.
2. Dialog

Dalam percakapan atau dialog haruslah memenuhi dua tuntutan

1) Dialog harus turut menunjang gerak laku tokohnya. Dialog haruslah dipergunakan untuk mencerminkan apa yang telah terjadi sebelum cerita itu, apa yang sedang terjadi di luar panggung selama cerita itu berlangsung dan harus pula dapat mengungkapkan pikiran-pikiran serta perasaan-perasaan para tokoh yang turut berperan di atas pentas.

2) Dialog yang diucapkan di atas pentas lebih tajam dna tertib daripada ujaran sehari-hari.

\section{Alur}

Alur adalah rangakaian peristiwa dan konflik yang dijalin dengan saksama dan menggerakan jalan cerita melalui rumitan ke arah klimks dan selesaian.

Jenis-jenis alur adalah sebagai berikut :

a. Alur maju, yaitu penceritaan rangkaian peristiwa yang paling awal sampai peristiwa terakhir

b. Alur mundur, yaitu penceritaan rangkaian peristiwa dari peristiwa yang paling akhir kemudian berbalik ke peristiwa yang paling awal

c. Alur campuran, yaitu perpaduan anatara maju dan alur mundur di dalam suatu cerita.

4. Latar 
Latar adalah keterangan mengenai tempat, ruang, dan waktu di dalam naskah drama. Latar terdapat beberapa bagian yaitu :

a. Latar tempat, yaitu penggambaran tempat kejadian di dalam naskah drama

b. Latar waktu, yaitu penggambaran waktu kejadian di dalam naskah drama

c. Latar budaya, yaitu penggambaran budaya yang melatarbelakangi terjadi adegan atau peristiwa dalam drama.

5. Tema

Tema adalah sesuatu yang menjadi dasar cerita, sesuatu yang menjiwai cerita, atau sesuatu yang menjadi pokok permasalahan dalam cerita.

6. Epilog

Epilog adalah kata penutup yang mengakhiri suatu lakon.

7. Amanat

Amanat adalah segala sesuatu yang ingin disampaikan pengarang, yang ingin ditanyangkan secara tidak langsung ke dalam benak para penotong dramanya.

\section{Jenis-Jenis Drama}

Drama masih dibagi menjadi beberapa jenis. Menurut Kosasih (2011:137) ada empat jenis drama, diantaranya :

1. Tragedi

Dalam tragedi umumnya memunculkan kisah yang sangat menyedihkan yang dialami seorang.

Tragedi adalah sejenis drama yang mempunyai ciri-ciri sebagai berikut.
a. Menampilkan kisah sedih
b. Cerita bersifat serius
c. Memunculkan rasa kasihan dan ketakutan
d. Menampilakn tokoh yang bersifat kepahlawanan

2. Komedi

Cerita ini umumnya menampilkankan cerita-cerita ringan. Drama ini mungkin pula memunculkan kisah serius namun dengan perlakuan nada yang ringan. Komedi mempunyai ciriciri sebagai berikut : 

a. Cerita ini umumnya menampilkan cerita-cerita ringan
b. Drama ini mungkin pula memunculkan kisah serius namun dengan perlakuan nada yang ringan
c. Cerita ini mengenai peristiwa-peristiwa yang kemungkinan terjadi
d. Kelucuan muncul dari tokoh dan bukan dari situsi

\section{Melodrama}

Melodrama mempunyai ciri-ciri sebagai berikut

a. Mengetengahkan serta menampilkan kisah yang serius.

b. Banyak memunculkan kejadian yang bersifat kebetulan.

c. Memunculkan rasa kasiah yang sifatnya sentimental.

\section{Farce}

Suatu farce mempunyai ciri-ciri sebagai berikut

a. Menimbulkan kelucuan yang tidak karua-karuan

b. Bersifat episodik, memerlukan kepercayaan yang sesaat

c. Kelucuan-kelucuan timbul dari situasi, bukan dari tokoh

\section{Pengertian Kearifan Lokal}

Kearifan lokal adalah identitas atau kepribadian budaya sebuah bangsa yang menyebabkan bangsa tersebut mampu menyerap, bahkan mengolah kebudayaan yang berasal dari luar/bangsa lai menjadi watak dan kemampuan sendiri Wibowo (2015:17). Identitas dan Kepribadian tersebut tentunya menyesuaikan dengan pandangan hidup masyarakat sekitar agar tidak terjadi pergesaran nilai-nilai. Kearifan lokal adalah salah satu sarana dalam mengolah kebudayaan dan mempertahankan diri dari kebudayaan asing yang tidak baik.Kearifan lokal adalah pandangan hidup dan ilmu pengetahuan serta berbagai strategi kehidupan yang berwujud aktivitas yang dilakukan oleh masyarakat lokal dalam menjawab berbagai masalah dalam pemenuhan kebutuhan mereka. Dalam bahasa asing sering juga dikonsepsikan sebagai kebijakan setempat local wisdom atau pengetahuan setempat "local knowledge" atau kecerdasan setempat local 
genious Fajarini (2014:123). Berbagai strategi dilakukan oleh masyarakat setempat untuk menjaga kebudayaannya.

\section{Kearifan lokal memiliki beberapa ciri-ciri yaitu:}

- Mempunyai kemampuan memgendalikan.

- Merupakan benteng untuk bertahan dari pengaruh budaya luar.

- Mempunyai kemampuan mengakomodasi budaya luar.

- Mempunyai kemampuan memberi arah perkembangan budaya.

- Mempunyai kemampuan mengintegrasi atau menyatukan budaya luar dan budaya asli.

Kearifan lokal merupakan pengetahuan eksplisit yang muncul dari periode yang panjang dan berevolusi bersama dengan masyarakat dan lingkungan di daerahnya berdasarkan apa yang sudah dialami. Jadi dapat dikatakan kearifan lokan disetiap daerah berbeda-beda tergantung lingkungan dan kebutuhan hidup.

\section{METODE}

Setiap penelitian memiliki pendekatan yang berbeda-beda, bergantung pada metode yang digunakan masing-masing. Pendekatan yang digunakan dalam tulisan ini adalah penelitian kualitatif deskriptif. Penelitian kualitatif merupakan penelitian yang bermaksud untuk memahami fenomena tentang apa yang dialami oleh subjek penelitian, misalnya perilaku, persepsi, motivasi, tindakan, dan lainlain. Pendekatan penelitian kualitatif ditentukan oleh karakter penelitian kualitatif, yang tentu berbeda dengan karakter penelitian kuantitatif.

Dilihat dari ruang lingkupnya, penelitian kualitatif dibagi ke dalam dua cakupan, yakni penelitian kepustakaan (library research) dan penelitian lapangan (field research). Penelitian kepustakaan mengandalkan data-data yang hampir sepenuhnya dari perpustakaan, sehingga penelitian ini lebih populer dikenal dengan penelitian kualitatif deskriptif kepustakaan atau penelitian bibliografis. Selain itu, penelitian kepustakaan sering juga diistilahkan dengan penelitian non-reaktif, karena sepenuhnya hanya mengandalkan data-data yang bersifat teoritis dan dokumentasi yang ada di perpustakaan. Sementara itu, penelitian lapangan mengandalkan 
data-datanya di lapangan (social setting) yang diperoleh melalui informan dan data-data dokumentasi yang berkaitan dengan subjek penelitian.

Penelitian pustaka atau studi pustaka tidak hanya sekadar urusan membaca dan mencatat literatur atau buku-buku. Penelitian pustaka merupakan rangkaian kegiatan yang berkenaan dengan metode pengumpulan data pustaka, membaca dan mencatat serta mengolah bahan penelitian. Adapun dalam tulisan ini, jenis penelitian yang digunakan adalah penelitian kualitatif deskriptif kepustakaan atau penelitian bibliografis, karena mengandalkan teori-teori dari buku sebagai literatur.

\section{HASIL DAN PEMBAHASAN}

\section{Langkah-langkah Menulis Drama}

Yonny (2014: 56) memberikan langkah atau cara praktis menulis drama (skenario), diantaranya :

1. Menentukan ide

Ide adalah rancangan yang tersusun dalam pikiran atau dikenal pula dengan gagasan. Langkah awal perjalanan panjang sebuah skenario dimulai dari ide.

2. Menentukan tokoh-tokoh cerita

Mengolah dan mempertajam ide dengan mengurainya menjadi lebih detail. Karena drama dibangun dari sebuah konflik maka langkah baiknya konflik di susun berdasarkan ide dasar.

3. Menentukan alur cerita

Alur cerita perlu ditentukan sehingga drama (film) tanpa dinamis sebagaimana kehidupan yang sesungguhnya. Penampilan peristiwa demi peristiwa hanya mendasarkan pada urutan waktu saja belum dikatakan alur (plot). Agar menjadi alur, peristiwa-peristiwa itu haruslah diolah dan disiasati dengan kreatif sehingga cerita ini memiliki efek emosional dan menarik. Misalnya,dipilih dan di rangkai peristiwa yang membuat penonton penasaran, selalu ingin tahu apa yang terjadi selanjutnya.

4. Menentukan latar cerita

Latar merupakan unsur yang cukup penting dalam pementasan drama (film). Latar dapat membangun imajinasi penonton.untuk pementasan drama panggung sebaiknya tidak terlalu banyak perubahan latar atau perpindahan latar karena secara teknis menyulitkan untuk tata panggungnya. 


\section{Macam Kearifan Lokal di Indonesia}

\section{Sasi [Maluku]}

Sasi merupakan aturan adat yang menjadi pedoman setiap warga Maluku dalam mengelola lingkungan termasuk pedoman pemanfaatan sumber daya alam.

\section{Tembawai [Dayak Iban-Kalimantan Barat]}

Tembawai merupakan hutan rakyat yang dikembangkan oleh masyarakat Dayak Iban di Kalimantan Barat, yang di dalamnya terdapat tanaman produktif seperti durian.

\section{Hompongan [Orang Rimba-Jambi]}

Hompongan merupakan hutan belukar yang melingkupi kawasan inti pemukiman Orang Rimba [di kawasan Taman Nasional Bukit Dua Belas, Jambi] yang sengaja dijaga keberadaannya yang berfungsi sebagai benteng pertahanan dari pihak luar.

\section{Awig-Awig [Lombok Barat dan Bali]}

Awig-Awig memuat aturan adat yang harus dipenuhi setiap warga masyarakat Lombok Barat dan Bali, dan sebagai pedoman dalam bersikap dan bertindak terutama dalam berinteraksi dan mengelola sumber daya alam dan lingkungan

\section{Repong Damar [Krui-Lampung Barat]}

Repong Damar atau Hutan Damar, merupakan model pengelolaan lahan bekas lading dalam bentuk wanatani yang dikembangkan oleh masyarakat Krui di Lampung Barat, yaitu menanami lahan bekas lading dengan berbagai jenis tanaman, antara lain Damar,karet,durian.

\section{Kapamalian [Banjar-Kalimantan Barat]}

Kapamalian merupakan aturan-aturan [pantangan] dalam pengelolaan lingkungan misalnya, larangan membuka hutan keramat.

\section{Moposad dan Moduduran [Bolaang Mongondow-Sulawesi Selatan] \\ Moposad dan Moduduran merupakan pranata tolong menolong yang penting untuk menjaga keserasian lingkungan.}




\section{Undang Undang Simbur Cahaya [Lahat-Sumatera Selatan]}

Undang Undang Simbur Cahaya yang sebagian substansinya mengatur tentang pentingnya pelestarian lingkungan.

\section{Ke-Kean [Sumatera Selatan]}

Pengetahuan Ke-Kean adalah perhitungan waktu yang tepat untuk menanam jenis tanaman tertentu yang dikaitkan dengan ilmu perbintangan.

\section{Rimba Kepungan Sialang [Melayu-Riau]}

Masyarakat Melayu mengenal pembagian hutan tanah yang terdiri dari 3 bagian, tanah perladangan, rimba larangan, rimba simpanan [hak ulayat], dan rimba kepungan sialang.

\section{KESIMPULAN}

Drama adalah bentuk karya sastra yang bertujuan menggambarkan kehidupan dengan menyampaikan pertikaian dan emosi melalui lakuan dan dialog. Menulis naskah drama diperlukan keseriusan yang menyenangkan. Hal tersebut supaya naskah drama terlihat menarik. Bahasa yang digunakan dalam menulis naskah drama adalah bahasa nonformal. Tujuannya adalah menghidupkan suasana dalam drama tersebut.

Sedangkan Kearifan lokal merupakan pengetahuan eksplisit yang muncul dari periode yang panjang dan berevolusi bersama dengan masyarakat dan lingkungan di daerahnya berdasarkan apa yang sudah dialami.

\section{DAFTAR PUSTAKA}

Dalman. 2014. Keterampilan Menulis. Jakarta : Rajagrafindo Persada

Keraf, Gorys. 2010. Diksi dan Gaya Bahasa. Jakarta: PT Gramedia Pustaka Utama

.2002. Diksi dan Gaya Bahasa. Jakarta: PT Gramedia Pustaka Utama

Kosasih, E. 2011. Ketatabahasaan dan Kesustraan.Bandung : Yrama Widya 
Panumbangan, Abraham.2013. Majas, Peribahasa Pembentukan Istilah SinonimAntonim.Yogyakarta : PT Suka buku

Purwanto, Ngalim. 2009. Prinsip-prinsip dan Teknik Evaluasi Pengajaran. Bandung: PT Rosdataria

Suastra, I.W. 2005. “Mengembangkan Pendidikan Berbasis Budaya Lokal di Sekolah. Jurnal Pendidikan dan Pengajaran” Jurnal Pendidikan, Volume 38, (3). Edisi Khusus (hlm.31-35)

PEMBELAJARAN MENULIS TEKS ARGUMENTASI BERBASIS KEARIFAN

LOKAL YANG BERORIENTASI PENDIDIKAN KARAKTER

PADA SISWA KELAS VIII

Oleh

Bernadetta Sormin

Pendidikan Bahasa dan Sastra Indonesia

Pascasarjana Universitas Negeri Medan bernadetta.sormin@gmail.com

\begin{abstract}
ABSTRAK
Bahasa dipelajari dalam bentuk empat keterampilan dasar, yaitu menyimak, berbicara, membaca, dan menulis. Kemampuan membaca diperlukan khususnya oleh siswa untuk kepentingan mencari literatur yang terkait dengan pelajaran yang mereka pelajari. Begitu pula, kebutuhan akan kemampuan menulis juga sangat dibutuhkan dalam dunia pendidikan. Banyak guru dan siswa yang beranggapan bahwa menulis itu merupakan keterampilan berbahasa yang paling sulit. karena banyak unsur yang terlibat di dalamnya, seperti unsur kebahasaan, isi (pesan yang akan disampaikan) dan ragam tulisan yang akan dibuat. kemampuan menulis teks argumentasi pada siswa dengan menggunakan model pembelajaran menulis teks argumentasi berbasis kearifan lokal yang berorientasi pendidikan karakter
\end{abstract}


dapat diterapkan. Kearifan budaya lokal selain memiliki nilai-nilai yang positif ternyata dapat membantu untuk meningkatkan kompetensi menulis catatan harian dan mengubah karakter siswa yang negatif menjadi positif. Kompetensi menulis siswa meningkat disebabkan sumber inspirasi yang berasal dari kearifan budaya lokal lebih mudah dipahami dan telah dikenali oleh siswa sebelumnya.

Kata kunci: teks argumentasi, kearifan lokal, pendidikan karakter.

\section{A. PENDAHULUAN}

Bahasa dipelajari dalam bentuk empat keterampilan dasar, yaitu menyimak, berbicara, membaca, dan menulis. Kemampuan membaca diperlukan khususnya oleh siswa untuk kepentingan mencari literatur yang terkait dengan pelajaran yang mereka pelajari. Begitu pula, kebutuhan akan kemampuan menulis juga sangat dibutuhkan dalam dunia pendidikan. Banyak guru dan siswa yang beranggapan bahwa menulis itu merupakan keterampilan berbahasa yang paling sulit. karena banyak unsur yang terlibat di dalamnya, seperti unsur kebahasaan, isi (pesan yang akan disampaikan) dan ragam tulisan yang akan dibuat. Sebagai akibat dari anggapan ini, pembelajaran materi menulis sering dihindari untuk diajarkan dengan berbagai alasan. Kemampuan menulis sangat penting untuk dikuasai peserta didik karena pada hakikatnya menulis merupakan sarana untuk menuangkan gagasan, pendapat, perasaan, keinginan, serta informasi ke dalam tulisan dan kemudian menginformasikannya kepada orang lain.

Kemampuan menulis sangat penting untuk dikuasai peserta didik karena pada hakikatnya menulis merupakan sarana untuk menuangkan gagasan, pendapat, perasaan, keinginan, serta informasi ke dalam tulisan dan kemudian menginformasikannya kepada orang lain. Keterampilan ini pun merupakan salah satu kegiatan yang kompleks karena penulis tidak hanya dituntut untuk dapat menyusun dan mengorganisasikan isi tulisannya tetapi harus mampu pula menuangkan gagasannya dalam bentuk bahasa tulis yang mudah dipahami pembaca. Selain itu, penulis harus mengikuti konvensi penulisan lainnya. Keterampilan menulis memiliki banyak manfaat, di antaranya dapat meningkatkan kecerdasan, dapat mengembangkan daya inisiatif dan kreativitas, menumbuhkan keberanian, serta dapat menjadi pendorong kemauan dan kemampuan mengumpulkan informasi (Suparno dan Yunus: 1.4).

Menurut Pennebeker menulis memiliki manfaat yang sangat besar, yaitu (1) menjernihkan pikiran, (2) mengatasi trauma; (3) membantu mendapatkan dan mengingat informasi baru, (4) membantu memecahkan masalah, (5) membantu kita ketika kita terpaksa harus menulis. Para pakar berpendapat bahwa kegiatan menulis itu sangat mudah asal sering dilatih secara intensif dan berkesinambungan. Salah satu kiat pelatihan menulis yang mudah dan jitu adalah menulis catatan harian secara intens. Sebagaimana Mirriam dan Goldberg (2006: 62) mengatakan bahwa menulis catatan harian secara teratur merupakan cara bagus untuk memperoleh kendali lebih besar atas penggunaan bahasa dan untuk mengasah keahlian seseorang sebagai penulis.

Alasan menulis teks argumentasi menjadi alternatif untuk meningkatkan kemampuan menulis siswa SMP didasarkan pada pendapat para pakar, yang mengatakan bahwa melalui kegiatan menulis teks argumentasi ini seorang calon penulis dapat memiliki kebebasan untuk mengekspresikan gagasan atau idenya. Selain keintensifan yang diperlukan untuk kegiatan pelatihan menulis, seorang calon penulis dapat dibantu untuk mendapatkan inspirasi sebanyakbanyaknya. Inspirasi yang paling dekat dengan 
kehidupan siswa SMP dan dialami langsung oleh mereka adalah budaya. Di dalam perwujudan budaya ini terkandung nilai-nilai kebaikan yang dapat menjadi inspirasi dan teladan siswa.

Nilai-nilai yang positif tersebut adalah kearifan budaya lokal. Kearifan budaya lokal dapat diinternalisasikan dalam pendidikan karena dia memiliki banyak kelebihan. Kelebihan tersebut antara lain sebagai berikut: (1) Kearifan budaya lokal dapat menjadi sarana pembelajaran bagi setiap manusia untuk menjadi orang yang cerdas, pandai, dan bijaksana, (2) Kearifan budaya lokal memiliki nilai-nilai positif untuk ditransformasikan kepada peserta didik guna membentuk kepribadian positif. Sebagaimana Sayuti (2009) mengemukakan bahwa budaya dan potensi lokal itu meniscayakan fungsi yang strategis bagi pembentukan karakter dan identitas. Atas dasar hal tersebut, selayaknyalah kearifan budaya lokal diintegrasikan dalam pembelajaran menulis catatan harian karena selain memberi inspirasi bahan tulisan, juga berfungsi untuk membentuk karakter dan identitas siswa itu sendiri.

Berdasarkan pada uraian tersebut, perlu dilakukan pengujian untuk membuktikan bahwa model pembelajaran menulis teks argumentasi berbasis kearifan budaya lokal yang berorientasi pendidikan karakter lebih efektif untuk meningkatkan kemampuan menulis siswa dan dapat memberikan banyak inspirasi bahan tulisan dan perubahan karakter siswa SMP.

\section{B. MODEL PEMBELAJARAN}

Model pembelajaran merupakan kerangka konseptual atau pola suatu pembelajaran. Kerangka konseptual atau pola tersebut dirancang untuk melaksanakan suatu pembelajaran yang di dalamnya tercakup tujuan-tujuan pengajaran, tahap-tahap dalam kegiatan pembelajaran, lingkungan pembelajaran, dan pengelolaan kelas. Semua unsur tersebut disusun secara sistematis untuk mengorganisasikan pengalaman belajar dalam rangka mencapai tujuan pembelajaran. Rancangan ini menjadi pedoman guru dalam mempersiapkan dan melaksanakan kegiatan belajar mengajar. Model ini dibuat dengan tujuan untuk membantu guru dalam mengaplikasikan kurikulum, mengembangkan materi ajar, dan melaksanakan pembelajaran di kelas.

Menulis teks argumentasi merupakan salah satu bentuk tulisan yang memberikan ide tentang suatu peristiwa. Kebiasaan menulis teks akan membantu meningkatkan kemampuan menulis. Demikian pula Semi (2007: 10) mengatakan bahwa kebiasaan menulis teks merupakan kebiasaan yang sangat baik dan sangat menunjang di dalam meningkatkan keterampilan menulis.

Kearifan Budaya Lokal Secara umum local wisdom (kearifan setempat) dapat dipahami sebagai gagasangagasan setempat (local) yang bersifat bijaksana, penuh kearifan, bernilai baik, yang tertanam dan diikuti oleh anggota masyarakatnya. Sedangkan, yang dimaksud kearifan budaya adalah seluruh usaha dan hasil usaha manusia atau masyarakat yang dilakukan dan ditujukan untuk memberikan makna manusiawi dan membuat tata kehidupan manusiawi pula. Dalam rangka memenuhi kebutuhan hidupnya, usaha dan hasil budaya manusia diarahkan untuk meningkatkan harkat dan nilai-nilai luhur kemanusiaan. Pendidikan Karakter Pendidikan karakter merupakan kebutuhan yang vital untuk menghadapi tantangan regional dan global. Adanya tantangan regional dan global ini menuntut agar generasi muda (peserta didik) tidak hanya sekadar memiliki kemampuan kognitif saja, tapi juga aspek afektif dan moralitas. Untuk itu, pendidikan karakter sangat diperlukan untuk mencapai manusia yang 
memiliki integritas nilai-nilai moral yang menjadikan seseorang memiliki kepribadian hormat pada sesama, jujur, dan peduli terhadap lingkungan.

\section{TEKS ARGUMENTASI}

Keterampilan menulis merupakan salah satu bentuk keterampilan berbahasa yang sangat penting bagi peserta didik di samping keterampilan menyimak, berbicara, dan membaca baik selama pendidikan maupun dalam kehidupannya nanti di masyarakat. Keberhasilan siswa dalam mengikuti kegiatan belajarmengajar di sekolah banyak ditentukan kemampuannya dalam menulis. Oleh karena itu, pembelajaran menulis mempunyai kedudukan yang sangat strategis dalam pendidikan dan pengajaran. Menulis merupakan suatu keterampilan berbahasa yang produktif dan ekspresif. Dengan menulis seseorang akan lebih mengenali potensi dan kemampuan dirinya dalam berpikir, bernalar, berpengetahuan, mengembangkan gagasan dan menyerap berbagai informasi. Di samping itu, bagi yang rajin menulis akan terlatih dalam memperluas gagasan secara sistematis dan logis. Argumentasi adalah salah satu bentuk penulisan paragraf atau pendapat dalam sebuah kalimat yang menerangkan sebuah penjelasan, alasan, pembuktian, pro, dan kontra yang disertai alasan-alasan obyektif, fakta aktual, nyata, valid, dan kuat terhadap paragrapnya yang bertujuan untuk meyakini si pembaca agar merasa simpati, berpendapat yang sama dengan si pembaca, dan terpengaruhi.

Komposisi penulisan kalimat argumentasi tidak ditulis sembarang begitu saja. Secara umum ada 3 urutan struktur teks dalam menulis atau mengungkapkan kalimat argumentasi. Urutan inipun tidak boleh dibolak-balik atau diacak karena apabila hal tersebut dilakukan, maka akan membuat isi teks menjadi susah dipahami dan tidak mengalir. Tentu saja keadaan tersebut juga membingungkan dan menimbulkan salah pengertian pada para pembaca. Pendahuluan, bagian pendahuluan berisi latar belakang masalah atau pengenalan masalah. Kalimat yang digunakanpun cukup menarik dengan menggunakan gaya bahasa sedemikian rupa sehingga akan menarik perhatian si pembaca. Isi atau badan kalimat argumantasi, bagian ini berisi pendapat, ide, point of view, dan gagasan, yang disertai dengan fakta yang menguatkan sekaligus membuktikan gagasan tersebut benar adanya. Penutup yang terdiri dari kesimpulan akhir, berisi kesimpulan yang logis dan dapat diterima oleh nalar si pembaca.

\section{KEARIFAN LOKAL BUDAYA}

Secara umum local wisdom (kearifan setempat) dapat dipahami sebagai gagasan-gagasan setempat (local) yang bersifat bijaksana, penuh kearifan, bernilai baik, yang tertanam dan diikuti oleh anggota masyarakatnya. Sedangkan, yang dimaksud kearifan budaya adalah seluruh usaha dan hasil usaha manusia atau masyarakat yang dilakukan dan ditujukan untuk memberikan makna manusiawi dan membuat tata kehidupan manusiawi pula. Dalam rangka memenuhi kebutuhan hidupnya, usaha dan hasil budaya manusia diarahkan untuk meningkatkan harkat dan nilai-nilai luhur kemanusiaan.

\section{E. PENDIDIKAN KARAKTER}

Pendidikan karakter merupakan kebutuhan yang vital untuk menghadapi tantangan regional dan global. Adanya tantangan regional dan global ini menuntut agar generasi muda (peserta didik) tidak hanya sekadar memiliki kemampuan kognitif saja, tapi juga aspek afektif dan moralitas. Untuk itu, pendidikan 
karakter sangat diperlukan untuk mencapai manusia yang memiliki integritas nilai-nilai moral yang menjadikan seseorang memiliki kepribadian hormat pada sesama, jujur, dan peduli terhadap lingkungan.

\section{F. PENUTUP}

Berdasarkan hasil catatan di lapangan, dapat disimpulkan bahwa kemampuan menulis teks argumentasi pada siswa dengan menggunakan model pembelajaran menulis teks argumentasi berbasis kearifan lokal yang berorientasi pendidikan karakter dapat diterapkan. Kearifan budaya lokal selain memiliki nilai-nilai yang positif ternyata dapat membantu untuk meningkatkan kompetensi menulis catatan harian dan mengubah karakter siswa yang negatif menjadi positif. Kompetensi menulis siswa meningkat disebabkan sumber inspirasi yang berasal dari kearifan budaya lokal lebih mudah dipahami dan telah dikenali oleh siswa sebelumnya.

\section{DAFTAR RUJUKAN}

Aunurrahman. 2009. Belajar dan Pembelajaran, Bandung: Alfabeta.

Beetlestone, Florence.1998. Creative Children: Imaginative Teaching, Philadelphia: Open University Press.

Beetlestone, Florence. 2011. Creative Learning: Strategi Pembelajaran untuk Melesatkan Kreatifitas Siswa. Terjemahan Narulita Yusron. Bandung: Nusa media

De Porter, Bobbi, and Mike Hernacki. 2010. Quantum Learning: Membiasakan Belajar Nyaman dan Menyenangkan.Terrjemahan Alwiyah Abdurrahman. Bandung: Kaifa PT Mizan Pustaka.

Koesoema, Doni A.2007. Pendidikan Karakter: Strategi Mendidik Anak di zaman Global. Jakarta: PT Grasindo.

Komaidi, Didik. 2008. Aku Bisa Menulis. Yogyakarta: Sabda.

Munir, Abdullah. 2010. Pendidikan Karakter: Membangun Karakter Anak Sejak dari

Rumah. Yogyakarta: Pedagogia. 


\title{
MODEL BAHAN AJAR BAHASA DAN SASTRA INDONESIA YANG IDEAL DAN INOVATIF \\ Oleh : Dwi Budi Mulyono \\ Pendidikan Bahasa dan Sastra Indonesia \\ Pascasarjana UNIMED
}

\begin{abstract}
Abstrak
Pendidikan merupakan bagian yang sangat penting dan tidak terpisahkan dari perjalanan hidup manusia. Melalui pendidikan, kualitas sumber daya manusia dapat semakin meningkat seiring dengan meningkatnya pendidikan yang diperolehnya. Kualitas tersebut akan sangat dibutuhkan dalam persaingan untuk memperoleh sebuah peran dalam memasuki kehidupan global, untuk meraih kesejahteraan hidup. Di Indonesia sendiri, pendidikan mengalami berbagai macam perubahan yang dapat dilihat dari kurikulum yang argumentasinya lebih kepada kurikulum tersebut perlu diganti karena tidak sesuai dengan zaman atau era yang sedang terjadi sehingga diperlukan suatu pembaharuan. Secara umum tujuan penulisan ini adalah mendeskripsikan model bahan ajar bahasa dan satra Indonesia yang ideal dan inovatif. Materi pembelajaran yang dipilih untuk diajarkan oleh guru dan harus dipelajari siswa hendaknya berisikan materi atau bahan ajar yang benar-benar menunjang tercapainya standar kompetensi dan kompetensi dasar. Hasil penelitian yang diperoleh adalah menciptakan bahan ajar yang inovatif pendidik harus mengetahui tentang hal-hal yang dapat menunjang keberhasilan dalam proses belajar salah satunya yaitu mengetahui bahan ajar dan sumber belajar.

Kata Kunci : Model Bahan Ajar Bahasa dan Sastra Indonesia, Ideal, dan Inovatif
\end{abstract}




\section{A. PENDAHULUAN}

Pendidikan merupakan bagian yang sangat penting dan tidak terpisahkan dari perjalanan hidup manusia. Melalui pendidikan, kualitas sumber daya manusia dapat semakin meningkat seiring dengan meningkatnya pendidikan yang diperolehnya. Kualitas tersebut akan sangat dibutuhkan dalam persaingan untuk memperoleh sebuah peran dalam memasuki kehidupan global, untuk meraih kesejahteraan hidup. Dalam hal ini, pemerintah telah memberikan ramburambu dalam penyelenggaraan pendidikan di Indonesia melalui berbagai macam kebijakan, antara lain tertuang dalam perundang-undangan.

Undang-Undang Sistem Pendidikan Nasional No. 20 Tahun 2003 Bab II Pasal 3 menyatakan bahwa tujuan pendidikan nasional adalah mengembangkan potensi peserta didik agar menjadi manusia yang beriman dan bertakwa kepada Tuhan Yang Maha Esa, berakhlak mulia, sehat, berilmu, cakap, kreatif, mandiri dan menjadi warga negara yang demokratis dan bertanggung jawab.

Sistem pendidikan nasional dalam abad ke 21 menghadapi berbagai tantangan dalam mempersiapkan generasi penerus bangsa yang berkualitas dan berdaya saing. Pembangunan karakter bangsa merupakan bagian penting dan tidak terpisahkan dari pembangunan nasional. Kebijakan nasional pembangunan karakter bangsa ini disusun sebagai pelaksanaan amanat UU RI No. 17 tahun 2007 tentang Rencana Pembangunan Jangka Panjang Nasional Tahun 20052025 .

Pembangunan karakter bangsa adalah misi pertama dari delapan misi guna mewujudkan visi pembangunan nasional. Secara eksplisit keberhasilan pembangunan karakter bangsa ditandai dengan terbentuknya karakter bangsa yang tangguh, kompetitif, berakhlak mulia, bermoral, bertoleran, bergotong royong, patriotik, dinamis, berbudaya dan berorientasi iptek berdasarkan pancasila dijiwai oleh iman dan takwa kepada Tuhan Yang Maha Esa (Kemendiknas, 2010).

Kebijakan nasional pembangunan karakter bangsa ini sesuai Permendikbud No. 54 Tahun 2013 tentang Kompetensi Lulusan harus memiliki sikap, pengetahuan, dan keterampilan. Sikap memiliki perilaku yang mencerminkan sikap orang beriman, berakhlak mulia, berilmu, percaya diri, dan bertanggung jawab dalam berinteraksi secara efektif dengan lingkungan sosial dan alam dalam jangkauan pergaulan dan keberadaannya. Pelaksanaan pendidikan kepribadian atau karakter diatur dalam Peraturan Pemerintah Nomor 19 Tahun 2005 
tentang Standar Nasional Pendidikan Pasal 7 Nomor 2 yakni pada setiap tingkat pendidikan dilaksanakan melalui muatan dan atau kegiatan agama, akhlak mulia, kewarganegaraan, bahasa, seni dan budaya, dan pendidikan jasmani. Permendiknas tersebut menjelaskan bahwa salah satu cara mendidik kepribadian atau karakter melalui muatan bahasa.

Zaman sekarang, pendidikan merupakan batu pijakan untuk mencapai suatu negara dan bangsa yang berkualitas baik itu di lihat dari aspek psikomotorik, afektif serta kognitif yang dimiliki oleh individu dalam suatu kelompok atau masyarakat. Sehingga diperlukan suatu pendidikan yang mengairahkan dan menarik perhatian suatu individu agar dapat mengembangkan ketiga aspek tersebut agar tercapainya kualitas dari suatu bangsa dan negara.

Di Indonesia sendiri, pendidikan mengalami berbagai macam perubahan yang dapat dilihat dari kurikulum yang argumentasinya lebih kepada kurikulum tersebut perlu diganti karena tidak sesuai dengan zaman atau era yang sedang terjadi sehingga diperlukan suatu pembaharuan. Selain itu, Pendidikan di era-modern di tuntut dengan suatu hal yang baru, hal ini di karenakan dalam pengajaran suatu pembelajaran di suatu sekolah secara khusus berbeda-beda tergantung dari materi, media dan metode yang digunakan. Pengajaran yang konvensional saat ini membuat siswa merasa jenuh akan proses pembelajaran sehingga diperlukan suatu pembelajaran yang menarik perhatian siswa khususnya pada pendidikan sekolah dasar.

Melihat kondisi tersebut khususnya pendidikan di indonesia yang mengalami perubahan serta untuk dapat menarik perhatian siswa khususnya pada mata pelajaran bahasa indonesia maka diperlukan suatu model yang pas atau sesuai dengan materi atau topik yang sedang di bahas agar dapat menjadi suatu konsen bagi siswa di sekolah

Melihat hal ini, maka kami tertarik untuk menyusun penulisan dengan memperhatikan permasalahan tersebut maka judulnya penulisan ini adalah “ Model bahan ajar Bahasa dan Satra Indonesia yang ideal dan inovatif". Dalam penulisan ini, kami akan mendsekripsikan serta memperhatikan model yang bagaimana implementasikan di sekolah yang haru di kuasai oleh guru atau calon-calon perubahan agar dapat menjadi bekal bagi mereka kedepannya.

\section{B. KAJIAN TEORETIS}

\section{A. Pengertian Model}


Pemahaman model dapat dipahami dengan berbagai macam pengertian yang bermacammacam. Secara etimologi, model berasal dari bahasa italia yakni modello yang dapat diartikan dari berbagai dimensi, jika dari kata benda maka model diartikan sebagai jenis atau contoh, sedangkan dari kata sifat dapat dipahami sebagai teladang atau di ambil sebagai contoh dan yang terakhir dari kata kerja dipahami sebagai membuat dengan contoh. Dengan kata lain, model secara etimologi yakni sesuatu contoh. Dalam kamus besar bahasa indoneis (KBBI), model didefinisikan sebagai pola dari sesuatu yang dibuat atau yang dihasilkan atau barang tiruan. Maka dapat diambil kesimpulan, jika model dapat dipahami sebagai suatu jenis contoh dari suatu pola ( contoh, acuan, ragam dsb) yang dibuat untuk menghasilkan sesuatu.

Sedangkan Pembelajaran merupakan suatu rangkaian kegiatan untuk memungkinkan terjadinya proses belajar yang dirancang, dilaksanakan dan dievaluasi secara sistematis agar dapat mencapai tujuan pembelajaran tersebut secara aktif, efektif dan inovatif.

Pada model pembelajaran menurut Zaini, model pembelajaran adalah pedoman berupa program atau petunjuk strategi mengajar yang dirancang untuk mencapai suatu tujuan pembelajaran. Pedoman itu memuat tangguangjawab guru dalam merencanakan, melaksanakan dan mengevaluasi kegiatan pembelajaran. Salah satu tujuan dari penggunaan model pembelajaran adalah untuk meningkatkan kemampuan siswa selama belajar.

Menurut Sukmasari Model pembelajaran adalah suatu rencana mengajar yang melibatkan pola pembelajaran tertentu. Dalam pola tersebut dapat terlihat kegiatan guru, siswa, sumber belajar yang digunakan di dalam mewujudkan kondisi belajar atau sistem lingkungan yang menyababkan terjadinya belajar pada siswa.

Dari berbagai macam pengertian diatas maka dapat diambil kesimpulan model pembelajaran adalah suatu pola yang dijadikan pedoman dalam startegi mengajar untuk mencapai suatu tujuan pembelajaran.

Menurut Kemp et al.(1994), pengembangan bahan ajar merupakan suatu siklus yang kontinum. Pengembangan bahan ajar model ini dapat dimulai dari langkah manapun sesuai dengan siklus tersebut. Oleh karena itu, model pengembangan bahan ajar Kemp ini dapat memberi kesempatan kepada para pengembang untuk dapat memulai dari langkah manapun sesuai dengan kurikulum yang berlaku. Beberapa langkah dalam penyusunan bahan ajar (dalam Kemp et al, 1994), yaitu.

1. Identifikasi Masalah Pembelajaran (Instructional Problems) 
Mengidentifikasi adanya kesenjangan antara tujuan dalam kurikulum yang berlaku dengan fakta yang terjadi dilapangan.

2. Analisis Karakteristik Siswa (Leaner Characteristics)

Mengetahui karakteristik siswa yang meliputi ciri, kemampuan, dan pengalaman baik individual maupun berkelompok.

3. Analisis Tugas (Task Analysis)

Merinci isi mata pelajaran dalam bentuk garis besar untuk menguasai isi bahan kajian atau mempelajari keterampilan yang mencakup keterampilan kognitif, keterampilan psikomotor, dan keterampilan sosial.

4. Merumuskan Indikator (Instructional Objectives)

Mendesain kegiatan pembelajaran, kerangka kerja dalam mengevaluasi hasil belajar siswa dan panduan siswa dalam belajar.

5. Menyusun Materi Pembelajaran (Content Squencing)

Mengurutkan isi pokok bahasan berdasarkan pengetahuan prasyarat, familiaritas, kesukaran, minat serta perkembangan siswa.

6. Strategi Pembelajaran (Instructional Strategies)

Memilih strategi belajar mengajar yang sesuai dengan tujuan.

7. Pemilihan Media atau Sumber pembelajaran (Instructional Delivery)

Tujuan dari langkah ini adalah untuk memilih media atau sumber pembelajaran sesuai dengan tuntutan tujuan pembelajaran. Keberhasilan pembelajaran sangat tergantung pada penggunaan sumber pembelajaran dan media yang dipilih.

8. Instrumen Penilaian (Evaluation Instrument)

Menyusun instrumen penilaian untuk menilai hasil belajar yang disusun berdasarkan tujuan pembelajaran khusus yang telah dirumuskan sehingga kriteria yang digunakan adalah penilain acuan patokan.

9. Sumber Pembelajaran (Instructional Resources)

Melihat ketersediaan secara komersial, biaya pengadaan, waktu untuk menyediakannya serta menyenangkan bagi siswa dalam membuat media atau sumber pembelajaran.

10. Pelayanan Pendukung (Support Services) 
Menentukan keberhasilan pengembangan bahan ajar dengan memperhatikan ketersediaan anggaran, fasilitas, bahan, perlengkapan, kemampuan staf, pengajar, perancang pembelajaran, pakar, dan lain sebagainya

\section{Evaluasi Formatif (Formative Evaluation)}

Penilaian yang dilakukan setiap selesai satu unit proses pembelajaran untuk memberi informasi kepada pengajar atau tim pengembang seberapa baik program ini mencapai sasaran.

\section{Penilaian Sumatif (Summative Evaluation)}

Penilaian yang digunakan untuk menilai sejauhmana tujuan instruksional telah dicapai di akhir program pembelajaran.

\section{Revisi Perangkat Pembelajaran (Revision)}

Mengevaluasi dan memperbaiki perangkat pembelajaran yang dikembangkan. secara terus menerus pada setiap langkah pengembangannya.

\section{B. Pengertian Bahan Ajar}

Bahan ajar merupakan salah satu bagian penting dalam proses pembelajaran. Sebagaimana Mulyasa (2006: 96) mengemukakan bahwa bahan ajar merupakan salah satu bagian dari sumber ajar yang dapat diartikan sesuatu yang mengandung pesan pembelajaran, baik yang bersifat khusus maupun yang bersifat umum yang dapat dimanfaatkan untuk kepentingan pembelajaran.

Dick, Carey, dan Carey (2009: 230) menambahkan bahwa instructional material contain the conten either written, mediated, or facilitated by an instructor that a student as use to achieve the objective also include information thet the learners will use to guide the progress. Berdasarkan ungkapan Dick, Carey, dan Carey dapat diketahui bahwa bahan ajar berisi konten yang perlu dipelajari oleh siswa baik berbentuk cetak atau yang difasilitasi oleh pengajar untuk mencapai tujuan tertentu.

Widodo dan Jasmadi dalam Ika Lestari (2013: 1) menyatakan bahwa bahan ajar adalah seperangkat sarana atau alat pembelajaran yang berisikan materi pembelajaran, metode, batasanbatasan, dan cara mengevaluasi yang didesain secara sistematis dan menarik dalam rangka mencapai tujuan yang diharapkan, yaitu mencapai kompetensi dan subkompetensi dengan segala kompleksitasnya. 
Pengertian ini menggambarkan bahwa bahan ajar hendaknya dirancang dan ditulis sesuai dengan kaidah pembelajaran, yakni disesuaikan materi pembelajaran, disusun berdasarkan atas kebutuhan pembelajaran, terdapat bahan evaluasi, serta bahan ajar tersebut menarik untuk dipelajari oleh siswa.

Iskandarwassid dan Dadang Sunendar (2011: 171) mengungkapkan bahwa bahan ajar merupakan seperangkat informasi yang harus diserap peserta didik melalui pembelajaran yang menyenangkan. Hal ini menunjukkan bahwa dalam penyusunan bahan ajar diharapkan siswa benar-benar merasakan manfaat bahan ajar atau materi itu setelah ia mempelajarinya. Yana Wardhana (2010: 29) menambahkan bahwa bahan ajar merupakan suatu media untuk mencapai keinginan atau tujuan yang akan dicapai oleh peserta didik. Sedangkan menurut Opara dan Oguzor (2011: 66) mengungkapkan bahwa instructional materials are the audio visual materials (software/hardware) which can be used as alternative channels of communication in the teaching-learning process. Bahan ajar merupakan sumber belajar berupa visual maupun audiovisual yang dapat digunakan sebagai saluran alternatif pada komunikasi di dalam proses pembelajaran.

Berdasarkan kajian di atas, istilah bahan ajar yang digunakan dalam penelitian ini adalah suatu bahan/ materi pelajaran yang disusun secara sistematis yang digunakan guru dan siswa dalam pembelajaran bahasa Indonesia di sekolah untuk mencapai tujuan yang diharapkan.

\section{METODE}

Setiap penelitian memiliki pendekatan yang berbeda-beda, bergantung pada metode yang digunakan masing-masing. Pendekatan yang digunakan dalam tulisan ini adalah penelitian kualitatif deskriptif. Penelitian kualitatif merupakan penelitian yang bermaksud untuk memahami fenomena tentang apa yang dialami oleh subjek penelitian, misalnya perilaku, persepsi, motivasi,

tindakan, dan lainlain. Pendekatan penelitian kualitatif ditentukan oleh karakter penelitian kualitatif, yang tentu berbeda dengan karakter penelitian kuantitatif.

Dilihat dari ruang lingkupnya, penelitian kualitatif dibagi ke dalam dua cakupan, yakni penelitian kepustakaan (library research) dan penelitian lapangan (field research). Penelitian kepustakaan mengandalkan data-data yang hampir sepenuhnya dari perpustakaan, sehingga penelitian ini lebih populer dikenal dengan penelitian kualitatif deskriptif kepustakaan atau penelitian bibliografis. Selain itu, penelitian kepustakaan sering juga diistilahkan dengan 
penelitian non-reaktif, karena sepenuhnya hanya mengandalkan data-data yang bersifat teoritis dan dokumentasi yang ada di perpustakaan. Sementara itu, penelitian lapangan mengandalkan data-datanya di lapangan (social setting) yang diperoleh melalui informan dan data-data dokumentasi yang berkaitan dengan subjek penelitian.

Penelitian pustaka atau studi pustaka tidak hanya sekadar urusan membaca dan mencatat literatur atau buku-buku. Penelitian pustaka merupakan rangkaian kegiatan yang berkenaan dengan metode pengumpulan data pustaka, membaca dan mencatat serta mengolah bahan penelitian. Adapun dalam tulisan ini, jenis penelitian yang digunakan adalah penelitian kualitatif deskriptif kepustakaan atau penelitian bibliografis, karena mengandalkan teori-teori dari buku sebagai literatur.

\section{HASIL DAN PEMBAHASAN}

\section{A. Model Bahan Ajar Bahasa Dan Sastra Indonesia yang ideal}

Ada beberapa aspek yang perlu diperhatikan dalam bahan ajar bahasa dan sastra Indonesia yang ideal, yaitu :

1) Konsep adalah suatu ide atau gagasan atau suatu pengertian yang umum, misalnya sumber kekayaan alam yang dapat diperbarui.

2) Prinsip adalah suatu kebenaran dasar sebagai titik tolak untuk berpikir atau merupakan suatu petunjuk untuk berbuat/melaksanakan sesuatu.

3) Fakta adalah sesuatu yang telah terjadi atau yang telah dikerjakan/dialami. Mungkin berupa hal, objek atau keadaan. Jadi bukan sesuatu yang diinginkan atau pendapat atau teori. Contoh : Proklamasi Kemerdekaan RI adalah pada tanggal 17 Agustus 1945.

4) Proses adalah serangkaian perubahan, gerakan-gerakan perkembangan. Suatu proses dapat terjadi secara sadar atau tidak disadari. Dapat juga merupakan cara melaksanakan kegiatan operasional (misalnya di pabrik) atau proses pembuatan tempe, proses peubahan warna pada daun yang kena hama wereng dan sebagainya.

5) Nilai adalah suatu pola, ukuran atau merupakan suatu tipe atau model. Umumnya nilai bertalian dengan pengakuan atau kebenaran yang bersifat umum, tentang baik atau buruk misalnya: hukum jual beli, hukum koperasi unit desa, Bimas dan sebagainya. 
6) Keterampilan adalah kemampuan berbuat sesuatu dengan baik. Berbuat dapat berarti secara jasmaniah (menulis, berbicara dan sebagainya) dan dapat juga berarti rohaniah (membedakan, menganaliss dan sebagainya). Biasanya kedua aspek tersebut tidak terlepas satu sama lain, kendatipun tidak selalu demikian adanya. (Oemar Hamalik, 1978)

\section{B. Langkah-langkah dalam memilih bahan ajar yang ideal}

Materi pembelajaran yang dipilih untuk diajarkan oleh guru dan harus dipelajari siswa hendaknya berisikan materi atau bahan ajar yang benar-benar menunjang tercapainya standar kompetensi dan kompetensi dasar. Secara garis besar langkah-langkah pemilihan bahan ajar meliputi : (a) mengidentifikasi aspek-aspek yang terdapat dalam standar kompetensi dan kompetensi dasar yang menjadi acuan atau rujukan pemilihan bahan ajar, (b) mengidentifikasi jenis-jenis materi bahan ajar, (c) memilih bahan ajar yang sesuai atau relevan dengan standar kompetensi dan kompetensi dasar yang telah teridentifikasi tadi., dan (d) memilih sumber bahan ajar.

Secara lengkap, langkah-langkah pemilihan bahan ajar dapat dijelaskan sebagai berikut:

\section{1) Mengidentifikasi aspek-aspek yang terdapat dalam standar kompetensi dan} kompetensi dasar. Sebelum menentukan materi pembelajaran terlebih dahulu perlu diidentifikasi aspek-aspek standar kompetensi dan kompetensi dasar yang harus dipelajari atau dikuasai siswa. Aspek tersebut perlu ditentukan, karena setiap aspek standar kompetensi dan kompetensi dasar memerlukan jenis materi yang berbeda-beda dalam kegiatan pembelajaran. Sejalan dengan berbagai jenis aspek standar kompetensi, materi pembelajaran juga dapat dibedakan menjadi jenis materi aspek kognitif, afektif, dan psikomotorik. Materi pembelajaran aspek kognitif secara terperinci dapat dibagi menjadi empat jenis, yaitu: fakta, konsep, prinsip dan prosedur (Reigeluth, 1987). Materi jenis fakta adalah materi berupa nama-nama objek, nama tempat, nama orang, lambang, peristiwa sejarah, nama bagian atau komponen suatu benda, dan lain sebagainya. Materi konsep berupa pengertian, definisi, hakekat, inti isi. Materi jenis prinsip berupa dalil, rumus, postulat adagium, paradigma, teorema.Materi jenis prosedur berupa langkahlangkah mengerjakan sesuatu secara urut, misalnya langkah-langkah menelpon, cara-cara pembuatan telur asin atau cara-cara pembuatan bel listrik.Materi 
pembelajaran aspek afektif meliputi: pemberian respon, penerimaan (apresisasi), internalisasi, dan penilaian. Materi pembelajaran aspek motorik terdiri dari gerakan awal, semi rutin, dan rutin.

2) Memilih jenis materi yang sesuai dengan standar kompetensi dan kompetensi dasar. Materi yang akan diajarkan perlu diidentifikasi apakah termasuk jenis fakta, konsep, prinsip, prosedur, afektif, atau gabungan lebih daripada satu jenis materi. Dengan mengidentifikasi jenis-jenis materi yang akan diajarkan, maka guru akan mendapatkan kemudahan dalam cara mengajarkannya. Setelah jenis materi pembelajaran teridentifikasi, langkah berikutnya adalah memilih jenis materi tersebut yang sesuai dengan standar kompetensi atau kompetensi dasar yang harus dikuasai siswa. Identifikasi jenis materi pembelajaran juga penting untuk keperluan mengajarkannya. Sebab, setiap jenis materi pembelajaran memerlukan strategi pembelajaran atau metode, media, dan sistem evaluasi/penilaian yang berbeda-beda. Misalnya, metode mengajarkan materi fakta atau hafalan adalah dengan menggunakan "jembatan keledai", "jembatan ingatan" (mnemonics), sedangkan metode untuk mengajarkan prosedur adalah "demonstrasi".

3) Memilih sumber bahan ajar. Setelah jenias materi ditentukan langkah berikutnya adalah menentukan sumber bahan ajar. Materi pembelajaran atau bahan ajar dapat kita temukan dari berbagai sumber seperti buku pelajaran, majalah, jurnal, koran, internet, media audiovisual, dsb.

\section{Bagaimana model bahan ajar bahasa dan sastra Indonesia yang inovatif}

Dalam dunia pendidikan seringkali kita menemukan berbagai masalah dalam berbagai hal yang menyangkut tentang pengajaran, pembelajaran dan proses dalam suatu pembelajaran itu sendiri, salah satunya yaitu penggunaan metode pengajaran yang monoton dapat menjadian siswa sulit untuk menangkap berbagai informasi ataupun materi yang disampaikan. Baik pembelajaran secara indoor maupun outdoor. gurupun sering tidak memperhatikan metode yang digunakan apakah metode tersebut sesuai dengan pembelajaran yang terkait atau tidak, sebagian guru juga sering menggunakan satu metode pembelajaran untuk semua mata pelajaran, yang akibatnya siswa sering tidak merespon apa yang disampaikan oleh guru. Untuk menunjang 
keberhasilan dalam suatu proses pembelajaran guru dan siswa dituntut untuk selalu aktif dalam suatu pembelajaran yang berlangsung, seringkali guru yang aktif dan siswanyapun tidak mempunyai feedback terhadap apa yang disampaikan oleh guru. Untuk membangun metode pembelajaran yang inovatif guru dituntut untuk bisa memahami tingkat kemampuan siswa agar siswa dapat menumbuhkan sifat rasa percaya dirinya dan terdorong untuk mengikuti proses pembelajaran dengan baik.

(Andi Prastowo, 2015 dalam bukunya Panduan Kratif Membuat Bahan Ajar Inovati) menjelaskan bahwa pendidik juga harus mengembangkan diri, tidak hanya pada aspek fisik sementara seperti peningkatan jenjang pendidikan, banyaknya sertifikat dan pelatihan, ataupun sertifikat profesi pendidik (sebagai tanda atau bukti pendidik profesional). Akan tetapi, pengembangan diri mestinya merambah hingga pada ranah nonfisik, sikap, kebiasaan, profesionalisme, maupun perilaku dalam mengajar. Dalam sebuah pembelajaran inovatif para pendidik tampaknya juga kurang dalam mengembangkan kreatifitasnya dalam merencnakan, menyiapkan dan membuat bahan ajar secara matang yang kaya dengan inovasi sehingga menarik bagi para peserta didik.

Untuk menciptakan pembelajaran yang inovatif pendidik harus mengetahui tentang halhal yang dapat menunjang keberhasilan dalam proses belajar salah satunya yaitu mengetahui bahan ajar dan sumber belajar. Jika dipahami secara rinci bahan ajar dan sumber belajar itu berbeda bahan ajar merupakan segala sesuatu (benda, data, fakta, ide dll) yang bisa menimbulkan proses belajar sedangkan bahan jar yaitu segala bahan (baik informasi, alat, maupun teks) yang disusun secara sistematis yang menampilan sebuah bentuk yang utuh dari kompetensi yang akan dikuasai oleh peserta didik dengan tujuan untuk perencanaan dan penelaahan implementasi pembelajaran.

Menurut National Centre for Competency Based Training (2007), bahan ajar adalah segala bentuk bahan yang digunakan untuk membantu guru atau instruktur dalam melaksanakan proses pembelajaran dikelas. Dengan demikian bahwa bahan ajar merupakan sarana terpenting yang harus diketahui, dipersiapkan, dan diperhatikan pendidik sebelum melakukan proses pembelajaran berlangsung. Dari beberapa pandangan mengenai pengertian bahan ajar, dapat kita pahami bahwa bahan ajar merupakan segala bahan baik informasi, alat, maupun teks yang disusun secar sistematis, yang menaimpilkan sosok utuh dari kompetensi yang akan dikuasai peserta didik dan digunakan dalam proses pembelajaran dengan tujuan perencanaan dan 
penelaahan implementasi pembelajaran. Misalnya buku pelajaran, modul, handout, LKS, model atau maket, bahan ajar audio, bahan ajar interaktif dan sebagainya. Terdapat berbagai unsurunsur bahan ajar yang harus dipahami yaitu :

1) Petunjuk beelajar yaitu komponen utama yang meliputi petunjuk bagi pendidik maupun peserta didik yang didalamnya dijelaskan tentang bagaimana pendidik sebaiknya mengajarkan materi kepada peserta didik dan sebagaiman pula peserta didik sebaiknya mempelajari materi yang ada dalam bahan ajar tersebut.

2) Kompetensi yang akan dicapai maksud dari komponen tersebut adalah kompetensi yang akan dicapai oleh siswa. Pendidik harus menjelaskan dan mencantumkan dalam bahan ajar yang sudah disusun dengan standart kompetensi, kompetensi dasar, maupun indikator pencapaian hasil belajar yang harus dikuasai peserta didik.

3) Informasi pendukung merupakan berbagai informasi tambahan yang dapat melengkapi bahan ajar, sehingga peserta didik akan semakin mudah menguasai pengetahuan yang akan mereka peroleh.

4) Latihan-latihan merupakan suatu bentu tuga yang diberikan peserta didik untuk melatih kemampuan siswa setelah mempelajari bahan ajar.

5) Petunjuk kerja atau lembar kerja adalah suatu lembar atau beberapa lembar kertas yang berisi sejumlah langkah prosedural cara pelaksanaan aktivitas atau kegiatan tertentu yang harus dilakukan peserta didik berkaitan dengan praktik dan sebagainya.

6) Evaluasi dalam komponen evaluasi terdapat sejumlah pertanyaan yang ditujukan kepada peserta didik untuk mengukur seberapa jauh penguasaan kompetensi yang berhasil mereka kuasai setelah mengikuti proses pembelajaran.

Sumber belajar, menurut website BCED, sumber belajar didefinisikan sebagai informasi yang disajikan dan disimpan dalam berbagai bentuk media, yang dapat membantu peserta didik dalam belajar sebagai perwujudan dari kurikulum. Sedangkan menurut Saudjana dan Rivai (1987:77), sumber belajar adalah segala daya yang dapat dimanfaatkan guna memberi kemudahan kepada seseorang dalam belajarnya. Dari beberapa pandangan diatas bahwasanya sumber belajar merupakan segala sesuatu (bisa berupa benda data, ide, dan sebagainya) yang 
bisa menimbulkan proses belajar. Adapaun contoh dari sumber belajar itu sendiri antara lain buku, paket, modul, LKS, (benda nyata yang digunakan sebagai sumber belajar), model, maket, bank, museum, kebun binatang dan sebagainya. Dengan demikian dalam mencari sumber belajar kita dapat menemukan kapan saja dan dimana saja, tinggal bagaimana para pendidik itu bisa memanfaatkan dan mengolahnya menjadi bahan ajar yang menarik dan inovatif.

Memahami isi bahan ajar:

1) Pengetahuan yang meliputi fakta, konsep, prinsip, dan prosedur : Fakta yaitu segala hal yang berwujud kennyataan dan kebenaran, meliputi nama-nama segala hal yang berwujud pengertian baru yang bisa timbul sebagai hasil pemikiran, meliputi definisi, pengertian, ciri khusus, hakikat, inti/isi, dan sebagainya. prinsip yaitu hal-hal utama pokok, dan memiliki posisi terpenting, meliputi dalil, rumus, adagium, posyulat, paradigma, teorema, serta hubungan antar konsep yang menggambarkan implikasi sebab akibat.

2) Keterampilan adalah materi atau bahan pembelajaran yang berhubungan dengan, kemampuan mengembangkan ide, memilih, menggunakan bahan, menggunakan peralatan, dan teknik kerja.

3) Dari pembahasan diatas dapat disimpulkan bahwasanya bahan ajar merupakan segala hal atau bahan yang digunakan pendidik atau instruktur dalam proses belajar. Untuk memeberikan bahan ajar yang inovatif pendidik harus memahami seberapa jauh minat siswa, bakat siswa agar dapat menyesuaikan dengan kondisi siwa agar siswa dapat menerima materi yang disampaikan oleh pendidik. Sebenarnya bahan ajar dapat kita temukan dimana saja tinggal bagaimana kita mengemas atau mengkonsepnya dengan menarik dan inovatif. Kegunaan sumber belajar tidak terlepas dari tujuan agar sumber belajar itu menjadi bermakna.

4) Bahan ajar merupakan sebuah susunan atas bahan-bahan yang berhasil dikumpulkan dari berbagai sumber belajar yang dibuat secara sistematis. Dengan demikian bahan ajar mempunyai unsur-unsur yang harus diperhatikan dalam pembuatan bahan ajar, supaya pendidik dapat memanfaatkan berbagai potensi sumber belajar yang melimpah disekitar kita secara maksimal.

\section{E. PENUTUP}

\section{Simpulan}


Model pembelajaran adalah suatu rencana mengajar yang melibatkan pola pembelajaran tertentu. Dalam pola tersebut dapat terlihat kegiatan guru, siswa, sumber belajar yang digunakan di dalam mewujudkan kondisi belajar atau sistem lingkungan yang menyababkan terjadinya belajar pada siswa.

Bahan ajar adalah seperangkat sarana atau alat pembelajaran yang berisikan materi pembelajaran, metode, batasan-batasan, dan cara mengevaluasi yang didesain secara sistematis dan menarik dalam rangka mencapai tujuan yang diharapkan, yaitu mencapai kompetensi dan subkompetensi dengan segala kompleksitasnya.

Materi pembelajaran yang dipilih untuk diajarkan oleh guru dan harus dipelajari siswa hendaknya berisikan materi atau bahan ajar yang benar-benar menunjang tercapainya standar kompetensi dan kompetensi dasar.

Untuk menciptakan bahan ajar yang inovatif pendidik harus mengetahui tentang hal-hal yang dapat menunjang keberhasilan dalam proses belajar salah satunya yaitu mengetahui bahan ajar dan sumber belajar.

\section{DAFTAR PUSTAKA}

Arikunto, Suharsimi. 2010. Prosedur Penelitian Suatu Pendekatan Praktek. Jakarta: PT. Rineka Cipta. Ary, Donald., Jacobs, Luchy Cheser., \& Razavieh, Asghar. 2004. Pengantar Penelitian dalam Pendidikan. Terjemahan oleh Rurchan, Arief. 2007. Yogyakarta: Pustaka Pelajar. Djumingin, Sulastriningsih \& Syamsudduha. 2009. Perencanaan Pembelajaran Bahasa dan Sastra Indonesia. Makassar: Badan Penerbit UNM. Gintings, Abdorrakhman. 2008. Esensi Praktis Belajar dan Pembelajaran. Bandung: Humaniora. Hamalik, Oemar. 2010. Psikologi Belajar dan Mengajar. Bandung: Sinar Baru Algesindo. Iskandarwassid \& Dadang Sunendar. 2011. Strategi Pembelajaran Bahasa. Bandung: PT. Remaja Rosdakarya. Kunandar. 2011. Guru Profesional: Implementasi Kurikulum Tingkat Satuan Pendidikan (KTSP) dan Sukses dalam Sertifikasi Guru. Jakarta: Rajawali Pers. Mulyasa, E. 2005. Menjadi Guru Profesional. Bandung: Remaja Rosdakarya. Musfah, Jejen. 2011. Peningkatan Kompetensi Guru: Melalui Pelatihan dan Sumber Belajar Teori dan Praktik. Jakarta: Kencana. Sanjaya, Wina. 2011. Strategi 
Pembelajaran Berorientasi Standar Proses Pendidikan. Jakarta: Kencana. Syaefudin, Udin. 2009. Inovasi Pendidikan. Bandung: Alfabeta.

Ghazali,A.Syakur.2010.Pembelajaran Keterampilan Berbahasa dengan Pendekatan Komutatif Interaktif. Bandung: PT.Refika Aditama.

Pranowo.2014.Teori Belajar Bahasa untuk Guru Bahasa dan Mahasiswa Jurusan Bahasa. Yogyakarta: Pustaka Belajar. 


\title{
KURIKULUM DAN PROBLEMATIKA PEMBELAJARAN BAHASA DAN SASTRA INDONESIA
}

\author{
Elisa Anggraini \\ Pendidikan Bahasa dan Sastra Indonesia \\ Pascasarjana Universitas Negeri Medan
}

\begin{abstract}
ABSTRAK
Kurikulum 2013 adalah kurikulum pendidikan di Indonesia saat ini yang telah diberlakukan oleh Kementrian Pendidikan dan Kebudayaan (Kemendikbud) Indonesia. Tujuan dari kurikulum baru ini adalah untuk memajukan pendidikan serta membenahi karakter pelajar di Indonesia. Masalah pokok dalam tulisan ini difokuskan pada problematika pembelajaran bahasa dan sastra Indonesia ditinjau dari permasalahan faktor guru, siswa, dan bahan/materi ajar serta unsur media pembelajarannya. Tujuan dari penulisan ini untuk mengetahui problematika yang dihdapi guru dalam pembelajaran bahasa Indonesia dan kaitnnya dengan kurikulum. Berdasarkan tujuan, tulisan ini dapat dikatagorikan sebagai penelitian deskriptif kualitatif, yaitu mengumpulkan informasi mengenai status suatu gejala yang ada. Kemudian mendeskripsikannya sesuai data yang diperoleh di lapangan. Penulis menggali data yang dianggap sesuai dengan penelitian ini. Data yang akan digali dalam penelitian ini sebagai berikut: aspek guru dalam mengajar, yaitu data problematika guru dalam mengajar, aspek siswa, kesulitan-kesulitan siswa dalam belajar bahasa Indonesia, dan aspek materi dan media pembelajaran yang mendukung proses belajarmengajar bahasa Indonesia.
\end{abstract}

Kata kunci: kurikulum, problematika, guru, siswa, dan media

\section{PENDAHULUAN}

Kurikulum 2013 adalah kurikulum pendidikan di Indonesia saat ini yang telah diberlakukan oleh Kementrian Pendidikan dan Kebudayaan (Kemendikbud) Indonesia. Tujuan dari kurikulum baru ini adalah untuk memajukan pendidikan serta membenahi karakter pelajar di Indonesia. Kurikulum 2013 ini mencakup beberapa mata pelajaran, salah satunya adalah bahasa Indonesia. Penerapan kurikulum baru ini diharapkan dapat membuat siswa selalu berpikir kritis dan kreatif.

Perubahan kurikulum dilakukan untuk menjawab tantangan zaman yang terus berubah agar peserta didik mampu bersaing di masa depan. Guru merupakan penentu dalam keberhasilan impelementasi kurikulum. Namun, perubahan kurikulum tidak selalu berakibat baik, apabila tidak sejalan dengan SDM yang memadai dari pelaksana kurikulum. Secanggih apapun kurikulum, tetapi apabila guru sebagai pelaksana tidak bisa menerapkannya maka kurikulum 
tersebut akan gagal. Dengan demikian, guru haruslah memahami konsep setiap kurikulum yang sedang diberlakukan, baik secara teoritis maupun praktis.

Dalam dinamika kehidupan masyarakat, bangsa Indonesia dituntut untuk membekali diri dengan seperangkat kompetensi agar dapat bersaing dan tetap eksis sebagai bangsa yang mandiri di tengah percaturan global. Seperangkat kemampuan tersebut meliputi kemampuan berkomunikasi, kemampuan berpikir jernih dan kritis, kemampuan mempertimbangkan segi moral suatu permasalahan, kemampuan menjadi warga negara yang bertanggungjawab, kemampuan mencoba untuk mengerti dan toleran terhadap pandangan yang berbeda, kemampuan hidup dalam masyarakat yang mengglobal, memiliki minat luas dalam kehidupan, memiliki kesiapan untuk bekerja, memiliki kecerdasan sesuai dengan bakat/minatnya, memiliki rasa tanggung jawab terhadap lingkungan.

Untuk itu, inti dari kurikulum 2013 adalah pada upaya penyederhanaan, dan tematikintegratif. Kurikulum 2013 disiapkan untuk mencetak generasi yang siap dalam menghadapi masa depan. Oleh karena itu, kurikulum disusun untuk mengantisipasi perkembangan masa depan. Titik berat kurikulum 2013 bertujuan untuk mendorong peserta didik atau siswa agar mampu lebih baik dalam melakukan observasi, bertanya, bernalar, dan mengomunikasikan (mempresentasikan) yang mereka peroleh atau mereka ketahui setelah menerima materi pembelajaran di sekolah. Objek yang menjadi pembelajaran dalam penataan dan penyempurnaan kurikulum 2013 ini lebih menekankan pada fenomena alam, fenomena sosial, fenomena seni, dan fenomena budaya. Melalui pendekatan tersebut siswa diharapkan untuk memiliki kompetensi sikap, keterampilan, dan pengetahuan jauh lebih baik. Mereka akan lebih kreatif, inovatif, dan lebih produktif, sehingga nantinya mereka bisa sukses dalam menghadapi berbagai persoalan dan tantangan di zamannya, memasuki masa depan yang lebih baik. Atau dengan kata lain, tema pengembangan kurikulum 2013 adalah agar dapat menghasilkan insan Indonesia yang produktif, kreatif, inovatif, dan afektif melalui penguatan sikap (tahu mengapa), keterampilan (tahu bagaimana), dan pengetahuan (tahu apa) secara terintegrasi.

Kurikulum 2013 merupakan peralihan dari KTSP.Ciri khas Kurikulum 2013 yaitu pembelajarannya yang tematik integratif, menggunakan pendekatan saintifik, dan pendekatan penilaian menggunakan pendekatan otentik. Bentuk penilaian dalam kurikulum 2013 terlihat memiliki perbedaan yang cukup mendasar dengan kurikulum sebelumnya. Dengandemikian 
tidak semua guru memahami secara komperehensif pelaksanaan dari penilaian ontentik dalam kurikulum baru tersebut.

Adanya gema reformasi dalam sistem pendidikan, semua elemen pendidikan dituntut untuk meningkatkan kualitas diri. Tidak tertutup kemungkinan bahwa dalam proses ke arah kemajuan tersebut ditemukan pula berbagai problematika, salah satunya adalah problematika dalam bidang pembelajaran siswa dalam mata pelajaran bahasa Indonesia. Pelajaran bahasa Indonesia di sekolah masih menghadapi berbagai problematika, baik secara internal (diri guru dan siswa) maupun eksternal atau faktor pendukung lain dalam pembelajaran, seperti materi, metode, dan media pembelajaran.

Otonomi dalam penyelenggaraan pendidikan dan kebudayaan mempunyai implikasi dan tanggung jawab yang besar terhadap sekolah terutama guru. Hal ini menuntut guru, terutama guru bahasa Indonesia untuk lebih memiliki komptensi berbahasa Indonesia yang tinggi. Namun kenyataannya, pembelajaran bahasa masih menghadapi berbagai problema. Kenyataan seperti ini merupakan benih-benih timbulnya kendala atau problematika pembelajaran pada kurikulum 2013 secara umum dan mata pelajaran bahasa Indonesia secara khusus, sehingga perlunya penelitian ini dilakukan untuk menjawab apa saja problematika yang ada pada pembelajaran bahasa Indonesia berdasarkan kurikulum 2013. Untuk menjawab permasalahan tersebut, penelitian ini secara singkat akan menguraikan problematika dalam pembelajaran bahasa Indonesia, baik guru maupun siswa, dan materi ajarnya, khususnya terhadap bahasa Indonesia

Masalah pokok dalam tulisan ini difokuskan pada problematika pembelajaran bahasa dan sastra Indonesia ditinjau dari permasalahan faktor guru, siswa, dan bahan/materi ajar serta unsur media pembelajarannya. Bertolak dari fokus penelitian di atas, masalah penelitian ini dapat dirumuskan sebagai berikut:

1. Bagaimana gambaran permasalahan pembelajaran bahasa Indonesia ditinjau dari faktor guru yang mengajar?

2. Bagaimana gambaran permasalahan pembelajaran bahasa Indonesia ditinjau dari faktor permasalahan siswa?

3. Bagaimana gambaran permasalahan pembelajaran bahasa Indonesia ditinjau dari faktor materi pembelajaran?

\section{METODE}


Penulis tentang kurikulum dan problematika pembelajaran bahasa Indonesia ini akan diteliti dengan deskripsi artinya membuat gambaran secara sistematis mengenai beberapa hubungan yang akan diteliti. Berdasarkan tujuan, tulisan ini dapat dikatagorikan sebagai penelitian deskriptif kualitatif, yaitu mengumpulkan informasi mengenai status suatu gejala yang ada. Kemudian mendeskripsikannya sesuai data yang diperoleh di lapangan.

Penulis menggali data yang dianggap sesuai dengan penelitian ini. Data yang akan digali dalam penelitian ini sebagai berikut.

1. Aspek guru dalam mengajar, yaitu data problematika guru dalam mengajar.

2. Aspek siswa, kesulitan-kesulitan siswa dalam belajar bahasa Indonesia.

3. Aspek materi dan media pembelajaran yang mendukung proses belajar-mengajar bahasa Indonesia.

\section{HASIL DAN PEMBAHASAN}

Pada tulisan ini, penulis mencantumkan beberapa pembahasan mengenai problematika pembelajaran bahasa Indonesia dari beberapa hasil penelitian yang telah dilakukan peneliti sebelumnya. Ada pun pembahasannya, yakni:

\section{a. Kurikulum}

Kurikulum 2013 adalah kurikulum pendidikan baru di Indonesia, yang baru saja diberlakukan oleh Kementrian Pendidikan dan Kebudayaan (Kemendikbud) Indonesia. Kurikulum 2013 ini masih baru dan sangat berbeda dari kurikulum sebelumnya sehingga banyak pro dan kontra yang timbul, dan hanya sekolah-sekolah yang ditunjuk saja yang mulai menggunakan kurikulum tersebut. Tujuan dari kurikulum baru ini adalah untuk memajukan

pendidikan serta membenahi karakter pelajar di Indonesia. Kurikulum 2013 ini mencakup beberapa mata pelajaran, salah satunya adalah bahasa Indonesia. Penerapan kurikulum baru ini diharapkan dapat membuat siswa selalu berpikir kritis dan kreatif. Berdasar penjelasan di atas, salah satu materi pembelajaran bahasa Indonesia yang dapat membuat siswa berpikir kritis adalah pembelajaran yang berbasis masalah, atau sering disebut Problem Based Learning. Pada pembelajaran ini, siswa dihadapkan pada suatu masalah dan siswa akan memecahkan atau menguraikan masalah tersebut dengan berbagai cara, seperti berdiskusi dengan teman. Guru hanya berperan sebagai 'pemancing' agar siswa dapat menyelesaikan masalah tersebut. Contohnya pada materi teks anekdot, dalam membahas struktur dan ciri teks, guru 'memancing' 
siswa dengan menunjukkan salah satu contoh teks anekdot, kemudian siswa membedah struktur dan cirinya dengan membaca teks tersebut untuk kemudian didiskusikan bersama.

Selain Problem Based Learning, materi yang diterapkan kurikulum 2013 pada pembelajaran bahasa Indonesia adalah kontekstual. Jadi, siswa belajar dan memahami materimateri yang ada dan mengaitkannya dengan hal-hal sekitar yang berhubungan langsung dengan masyarakat. Contohnya adalah siswa dapat mengeluarkan pendapat dengan cara yang tepat, dengan bahasa yang baik dan benar. Pada materi teks anekdot misalnya, siswa diajak untuk menyampaikan pendapatnya dalam bentuk kritikan yang dikemas dalam bentuk teks anekdot. Dalam hal ini, tentu siswa harus mengetahui apa itu teks anekdot, bagaimana struktur dan bahasanya, apa saja ciri dan kaidah penulisannya, bagaimana contohnya, sebelum siswa dapat membuat teks anekdot. Meskipun sudah dijelaskan langsung oleh guru, secara tidak langsung siswa pasti juga akan mencari tahu sendiri supaya hasil tulisannya lebih baik.

Pembelajaran kurikulum 2013 juga mengacu pada pendekatan ilmiah, dengan adanya beberapa kegiatan, yaitu mengamati, menanya, menalar, mencoba, dan mengkomunikasikan. Siswa dipacu untuk mengamati lingkungan dan keadaan sekitar, mencari tahu apa yang terjadi dan mencoba mengkomunikasikannya. Hal ini selain mendorong siswa untuk berpikir kritis, juga mendorong siswa untuk menjadi proaktif. Seperti pada materi teks anekdot, guru mengarahkan siswa dengan memberi tugas mencari contoh teks anekdot, kemudian siswa akan merombaknya dengan mengganti subjek/tokohnya menjadi subjek/tokoh yang dekat dengan sekitarnya. Untuk melakukannya, siswa pasti akan mengamati terlebih dahulu, kemudian mencari tahu dan menalarnya, setelah itu, baru mencoba menulis untuk mengkomunikasikannya kembali.

Aspek penilaian pada kurikulum 2013 ini tidak hanya berdasar pada nilai kognitif atau kepintaran yang berdasarkan pada nilai tes, tugas atau ulangan. Tetapi juga berdasarkan aspek afektif dan juga psikomotor/praktik. Aspek afektif adalah penilaian tingkah laku siswa seharihari, bagaimana siswa bersikap dalam menerima pembelajaran, bertutur kata dengan sopan pada guru maupun sesama siswa, dan lain-lain. Sementara aspek psikomotor dinilai berdasarkan keaktifan siswa dalam kelas dan praktik yang dilakukan siswa pada tiap-tiap materi. Salah satu contohnya ada pada materi teks anekdot, yaitu siswa membacakan teks anekdot di hadapan siswa-siswa lain untuk kemudian dinilai.

Pada intinya, kurikulum 2013 akan sangat berperan dalam memajukan pendidikan dan membentuk karakter pelajar di Indonesia. Selain itu, kurikulum 2013 juga akan menghasilkan 
siswa-siswa yang memiliki pribadi yang cerdas dan mampu berpikir kritis dan kreatif serta peduli pada lingkungan sekitarnya, apabila dilaksanakan dengan baik dan benar, sesuai dengan kaidah dan peraturannya.

Berdasarkan hasil tinjau pustaka yang dilakukan oleh penulis maka dapat dijabarkan bahwa dalam pembelajaran bahasa Indonesia pada kurikulum 2013 ini terdapat beberapa problematika pembelajaran bahasa Indonesia, beberapa katagori problematika pembelajaran bahasa Indonesia yang peneliti deskripsikan sebagai berikut.

\section{b. Problematika Pembelajaran bahasa Indonesia}

\section{a. Problematika yang Dihadapi Guru dalam Proses Pembelajaran Bahasa Indonesia}

1. Format materi ajar dan tugas-tugas siswa, guru sepenuhnya mengacu pada materi yang terdapat dalam buku siswa dan petunjuk guru. Guru mengalami kesulitan dalam mengintegrasikan materi yang ada dalam buku siswa dan buku petunjuk guru sehingga bagi guru yang mengajarkan jadi kendala dalam menafsirkan maksud dalam buku siswa dengan yang ada dalam buku guru. Karena kedua buku tersebut tidak terintegrasi satu sama lain.

2. Guru belum begitu memahami penerapan pendekatan saintifik yang disarankan kurikulum 2013 sehingga pembelajaran bahasa Indonesia masih berpusat pada guru, bukan berpusat pada siswa. Hal ini terjadi karena siswa dan guru sudah terbiasa menggunakan metode mengajar dengan pola monoton, sulit bagi guru mengubahnya.

3. Guru dalam mengajarkan bahasa Indonesia kepada siswa belum memiliki perangkat penilaian otentik yang lengkap, dan belum menerapkan penilaian tersebut. Hal ini terjadi karena faktor ketidakpahaman guru dalam menerapkan penilaian tersebut atau karena guru malas dalam membuat dan memahami perangkat penilaian yang ada. Untuk itu, perlunya guru pada waktu mengajar mempersiapkan perangkat penilaian yang yang tepat sesuai karakteristik siswa.

4. Dalam mengajar, guru harus mampu menguasai berbagai macam model pembelajaran dengan baik. Kondisi di lapangan tidak semua guru mampu menguasai model-model pembelajaran yang diinginkan oleh kurikulum 2013. 
5. Siswa dalam mengerjakan tugas yang terdapat dalam buku pegangan siswa, literatur, dan contoh sangat sedikit karena acuan buku lebih banyak kepada IPA sehingga guru kesulitan dalam mengembangkan materi pelajaran karena keterbatasan referensi materi mengenai ilmu alam tersebut. Guru hanya mengacu materi yang ada dalam buku siswa, kalau proses pembelajaran lebih baik, guru lebih dulu harus mencari informasi dari sumber lain seperti di internet. Apabila hal tersebut tidak dilaksanakan, guru tidak bisa langsung dengan percaya diri tampil di depan kelas.

6. Dalam buku pegangan siswa, apabila guru tidak membaca dan memahami (menganalisis) terlebih dulu buku pegangan siswa, guru juga akan kesulitan untuk mengkomunikasikan tugas-tugas kepada siswa. Untuk itu, guru diminta sebelum memerintahkan siswa untuk memahami dan mengerjakan tugas dalam buku tersebut, guru terlebih dahulu menjelaskan maksud kalimat (soal) yang tertulis dalam buku siswa serta menjelaskan contoh-contoh yang ada dalam buku. Apabila tidak dijelaskan, siswa akan mengalami kesulitan dalam mengerjakan tugas.

7. Karena banyak tugas yang harus dikerjakan oleh siswa, guru harus juga banyak menggunakan waktu untuk mengoreksinya. Untuk itu, tinggal kesediaan guru dan ketekunan guru dalam melaksanakan tugas tersebut. Karena penilaian otentik mengacu pada tiga ranah penilaian, yaitu penilaian sikap, pengetahuan, dan keterampilan. Yang menjadi kendala, apabila guru tidak melaksanakan ketiga konsep penilaian tersebut dalam proses pembelajaran di kelas.

\section{b. Problematika Siswa dalam Pembelajaran bahasa Indonesia}

1. Siswa memiliki keberagaman kompetensi, pengetahuan, dan keterampilan sehingga guru harus memiliki kesabaran untuk membimbing siswa sampai tuntas, baik siswa memiliki kemampuan berpikir cepat, sedang, dan lambat. Kesemua kompetensi tersebut dalam kurikulum 2013 harus terayomi dengan baik dan sesuai dengan kondisi siswa yang ada di kelas. Apabila hal tersebut tidak terlaksana, komponen penting dalam kurikulum 2013 tidak akan tercapai maka siswa mengalami kendala dalam mengikuti pelajaran. Solusinya pada saat proses belajar-mengajar, guru harus jeli dalam melihat potensi siswa yang ada.

2. Kemampuan anak yang rata-rata kecerdasannya lambat, guru perlu memperjelas materi dengan dengan membimbing siswa secara penuh, sehingga terkesan guru lebih aktif, 
bukan siswanya yang aktif. Materi pelajaran yang ada dalam buku siswa, masih seputar tema pelajaran I, "Gemar Meneroka Alam Semesta”. Lambatnya penggunaan buku siswa tersebut, telah diakui oleh guru yang bersangkutan bahwa hal itu disebabkan lemahnya potensi kecerdasan siswa dalam memahami dan menyerap pelajaran dalam buku siswa.

3. Materi yang ada dalam buku siswa cukup sulit bagi siswa yang wawasan pengetahuannya terbatas atau siswa yang daya nalarnya katagori $\mathrm{C}$ (lambat berpikir) untuk memahami buku teks pelajaran, siswa katagori ini harus dibantu oleh guru secara penuh agar siswa dapat memahami pelajaran dengan baik dan sesuai dengan tuntutan kurikulum.

4. Perlu mengintegrasikan materi yang diajarkan dengan pemahaman dan pengetahuan yang dimiliki siswa.

5. Adanya istilah teknis yang tidak umum dan sulit dipahami siswa, perlu dijelaskan oleh guru secara lebih lengkap agar siswa lebih memahami materi pembelajaran. Bisa juga disarankan oleh guru agar siswa lebih dulu membaca buku-buku yang relevan dengan materi ajar sehingga proses pembelajaran di kelas menjadi lebih hidup dan siswa menjadi aktif.

6. Tidak adanya petunjuk yang jelas untuk menggunakan buku siswa dengan baik pada waktu proses belajar-mengajar. Guru yang tidak kreatif hanya mengikuti materi sesuai dengan apa yang dalam buku siswa, sehingga guru kesulitan memahami soal atau tugas yang ada dalam buku siswa.

7. Adanya ketidakefektifan waktu pada saat siswa menjawab soal dalam buku siswa, waktu terlalu banyak. Siswa masih terobsesi pada metode pembelajaran dengan sistem KTSP, guru lebih berperan aktif menjelaskan.

8. Dalam kurikulum baru, siswa ditekankan pada keaktifan siswa dalam melaksanakan tugas-tugas karena pada kurikulum 2013 ini ada banyak tugas yang dilakukan oleh siswa. Siswa yang tidak terbiasa dengan tugas-tugas atau latihan yang selalu ada dalam kurikulum ini, dia akan merasa keberatan atau paling tidak ada semacam keluhan.

9. Karena cakupan materi yang ada pada buku siswa lebih banyak materi ilmu alam, ada saja komentar dan pertanyaan siswa. Mengapa bahasa Indonesia, belajar IPA tentang binatang? Nah ini yang sering ditanyakan oleh siswa kepada gurunya sehingga guru sulit menjawabnya karena memang itu ada di kurikulum. Hal ini adalah tuntutan yang harus diselesaikan. Yang lebih parah lagi apabila guru kurang menguasai ilmu alam sehingga 
guru sulit melakukan implementasi atau memberikan jawaban pertanyaan siswa yang menyangkut ilmu pengetahuan alam ini.

10. Masalah lain seperti kesiapan siswa dalam menelaah dan mempelajari materi buku pegangan siswa. Karena materinya harus betul-betul dipahami dan siswa harus konsentrasi pada waktu membaca. Apabila siswa tidak konsentrasi, siswa akan mengalami kesulitan dalam memahami teks yang dibaca akibatnya akan berdampak pada kurang mampunya siswa mengerjakan tugas-tugas (soal-soal) yang ada dalam buku paket siswa. Solusinya sebagai guru tidak boleh melepaskan tanggung jawab bimbingan kepada siswa, karena ada guru membiarkan begitu saja siswa mengerjakan tugas, siswa kebingungan dalam mengerjakan tugas-tugas dan tidak dipandu oleh guru.

11. Setiap format latihan harus ditafsirkan oleh guru terlebih dahulu, baru disuguhkan kepada siswa. Tujuannya agar siswa lebih memahami tugas yang dikerjakannya apabila tugas yang dikerjakan dipahami siswa, guru tidak sulit lagi dalam membimbing siswa mengerjakan. Siswa akan mengerjakan secara mandiri. Sampai tugas tersebut selesai. Yang jadi kendala adalah apabila guru dan siswa belum mampu untuk menafsirkan permasalahan (soal) yang ada dalam buku siswa, sehingga guru dan siswa sama-sama meraba-raba alternatif jawaban yang benar sesuai dengan kemampuan dan pengetahuan yang dimiliki oleh guru.

12. Siswa harus sering berinteraksi dengan materi yang dihadapinya, tidak lagi bersifat teori tetapi harus real (nyata), untuk itu guru harus membawa contoh yang nyata tentang materi ajar yang diperagakan kepada siswa agar siswa lebih memahami.

13. Siswa dituntut untuk kreatif dengan banyak bertanya dalam mengerjakan tugas-tugas pada buku pegangan siswa kepada guru. Apabila tidak, siswa akan mengalami kesulitan dalam mengerjakan tugas, dan menjawab pertanyaan yang ada dalam buku siswa.

14. Bila hendak mengetahui siswa yang cerdas dan kreatif akan terlihat dengan kecepatan dan ketepatannya dalam menjawab-soal-soal yang ada dalam buku siswa.

\section{c. Problematika Materi dan Media dalam Pembelajaran Bahasa Indonesia}

1. Media berupa LCD masih terbatas di sekolah sehingga tidak semua kelas dapat menggunakan media tersebut ketika proses pembelajaran berlangsung. 
2. Sarana belajar penunjang berupa buku-buku penunjang yang ada di perpustakaan (sebagai referensi) masih terbatas. Hal ini membuat belum banyak memberikan wawasan atau pengetahuan baru bagi siswa. Siswa menjadi kesulitan untuk memahami bingung untuk menafsirkan materi yang ada dalam buku siswa.

3. Materi ajar dalam buku teks siswa, sebagian ada yang sulit dipahami oleh siswa. Hal ini disebabkan siswa belum terbiasa dengan masalah yang dikemukakan dalam buku pegangan siswa tersebut.

4. Adanya sebagian materi dalam buku siswa yang tidak sesuai dengan usia dan karakteristik siswa. Contoh teks prosedur kompleks tentang pembuatan Surat Izin Mengemudi (SIM), kendalanya siswa kelas X masih berumur di bawah 17 tahun, sedangkan SIM baru bisa dibuat apabila siswa berumur 17 tahun ke atas.

\section{d. Problematika Penilaian dalam Pembelajaran Bahasa Indonesia}

Penilaian adalah proses pengumpulan dan pengolahan informasi untuk mengukur pencapaian hasil belajar peserta didik. Penilaian merupakan serangkaian kegiatan untuk memperoleh, menganalisis, dan menafsirkan data tentang proses dan hasil belajar peserta didik yang dilakukan secara sistematis dan berkesinambungan, sehingga menjadi informasi yang bermakna dalam pengambilan keputusan. Penilaian dapat dilakukan selama pembelajaran berlangsung (penilaian proses) dan setelah pembelajaran usai dilaksanakan (penilaian hasil/produk).

1. Guru masih belum memiliki perangkat penilaian otentik secara lengkap yang diinginkan oleh kurikulum karena aspek penilaian ini belum sepenuhnya dilaksanakan oleh guru. Kalau pun dilaksanakan, penilaiannya hanya sebagian atau hanya sebatas penilaian sikap, sedangkan penilaian yang lain belum mengemuka. Hal ini dikarenakan waktu yang terbatas dengan format 2 x 40 menit, (untuk 1 x pertemuan). Pada saat mengajar, guru asyik membimbing siswa sehingga waktu untuk menerapkan penilaian terbatas bahkan ada yang tidak sempat.

2. Terlalu banyaknya format prosedur penilaian kepada siswa membuat guru sulit merangkum penilaian secara keseluruhan. 
3. Waktu untuk melakukan proses penilaian sangat sedikit. Hal ini biasa dilakukan guru pada saat pelajaran mulai berakhir. Waktu yang tersedia sangat singkat, tidak semua siswa dapat dinilai segala aktivitasnya pada waktu pembelajaran tersebut.

\section{SIMPULAN}

Berdasarkan paparan yang telah diungkapkan seblmnya bahwa dapat ditarik kesimpulan bahwa makala ini memiliki beberapa permasalahan yang telah ditemukan, permasalahan tersebut dijabarkan dalam beberapa faktor yang mengemuka dan ditentukan di lapangan pada saat meneliti. Beberapa faktor tersebut ada berupa permasalahan seperti faktor guru yang mengajar, faktor siswa, dan faktor materi pembelajaran.

Kendala atau problematika pembelajaran ditinjau dari faktor guru yang mengajar. Bila ditinjau dari faktor guru yang mengajar, permasalahan yang timbul adalah kurangnya kesiapan guru dalam menerapkan kurikulum 2013 dan kurang sumber daya guru yang mampu menterjemahkan dan mampu menafsirkan sesuai kehendak kurikulum 2013. Guru kebingungan dalam menerapkan kurikulum yang diinginkan oleh kurikulum 2013. Hal ini karena minimnya persiapan dan kompetensi guru dalam mengajar yang sesuai dengan kehendak kurikulum. Guru hanya merabaraba langkah-langkah yang diinginkan oleh kurikulum. Selain itu, tidak semua guru mengikuti pelatihan kurikulum 2013, kalau pun ada pelatihan, waktunya cukup singkat dan tergesa-gesa, sehingga tidak memenuhi target yang sesuai dengan apa yang diinginkan dalam kurikulum.

\section{DAFTAR RUJUKAN}

Driana, Elin. Gawat Darurat Pendidikan. Kompas, 14/12/2012.

Nasution, S. 1996. Metode Penelitian Naturalistik Kualitatif. Bandung: Tarsito.

Sudaryanto. 1993. Metode dan Teknik Analisa Bahasa, Pengantar Penelitian Wahana Kebudayaan secara Linguistik. Yogyakarta: Duta Wacana University Press. 


\title{
TEKNOLOGI INFORMASI DAN KOMUNIKASI BERUPA E-BOOK BERBASIS KEARIFAN LOKAL DALAM PENGEMBANGAN BAHAN AJAR BAHASA DAN SASTRA
}

\author{
Hainur Anisa \\ Pendidikan Bahasa Indonesia \\ Pascasarjana Universitas Negeri Medan
}

\begin{abstract}
Abstrak
Pengembangan materi merupakan dasar untuk belajar dan sebuah tanggung jawab praktis. Sebagai suatu dasar, materi mempelajari prinsip dan prosedur dalam mendesainnya, implementasi dan evaluasi materi pembelajaran bahasa. Mengkaitkan dengan kearifan lokal akan membuat siswa lebih mengenali budayanya masing-masing. Perkembangan zaman serba teknologi menjadi salah satu contoh perkembangan zaman yang tentu tidak dapat ditepis oleh siapapun. Para pelajar yang hidup pada era IT ini tentu akan merasa lebih tertarik dengan pembelajaran yang berbasis IT. rekayasa ini dimuculkan ide yang berkitan dengan pengembangan bahan ajar dan perkembangan zaman. Mengembangkan bahan ajar dalam bentuk buku digital pada masa sekarang ini merupakan pilihan yang tepat dilakukan para guru karena akan membuat siswa lebih tertarik. Kebutuhan dalam dunia pendidikan sangatlah kompleks mulai dari kebutuhan sumber ilmu, yaitu buku, guru yang handal, tempat yang memadai, dan kebutuhan penunjang lainnya. E-book adalah salah satu alternatif yang cukup baik karena sifatnya yang digital sehingga tidak menggunakan kertas dan hanya memerlukan seperangkat device yang dapat membacanya seperti HP, komputer, laptop, dan device-device lainnya. Dalam E-book terdapat beberapa format buku yang dapat digunakan. E-book ini nantinya akan berupa buku yang di dalamnya terdiri dari video, gambar, teks, audio, animasi, dan evaluasi berupa soal-soal yang menarik berbasis kearifan lokal.
\end{abstract}

Kata kunci: Bahan ajar, kearifan lokal, digital, e-book

\section{A. PENDAHULUAN}

Pembelajaran bukan kata yang asing bagi masyarakat. Widiasworo (2017:15) mendefinisikan pembelajaran sebagai suatu sistem atau proses membelajarkan subjek didik atau pembelajar yang direncanakan atau didesain, dilaksanakan, dan dievaluasi secara sistematis agar pelajar dapat mencapai tujuan pembelajaran dengan efektif dan efisien.

Guru dianggap telah melakukan pembelajaran apabila telah terjadi perubahan perilaku pada pelajar. Hal ini berkaitan dengan pembelajaran efektif. Pembelajaran dikatakan sebagai 
pembelajaran efektif apabila pembelajaran itu tidak semata-mata memberikan dampak instruksional, tetapi juga memberi dampak pengiring positif. Lalu bagaimana menciptakan pembelajaran yang efektif dalam pembelajaran bahasa dan sastra?

Para pakar menyatakan bahwa pembelajaran harus didesain berdasarkan kebutuhan peserta didik. Pendapat tersebut didukung oleh Maley (dalam Azarnoosh, 2016: 11) yang menyatakan bahwa materi itu selalu berkembang. Materi merupakan bagian dari seluruh konteks pembelajaran bahasa untuk apa bahasa itu dan bagaimana orang-orang belajar bahasa. Materi hanya sebagian kecil dari pembelajaran, namun memiliki peranan yang sangat penting karena materi itu akan digunakan oleh guru, dipelajari oleh siswa, ditentukan penilaian hasilnya, dikaitkan dengan keadaan ekonomi dan kebudayaan yang ada di sekitar siswa. Kebudayaan tersebut berupa perkembangan teknologi saat ini. Para pelajar yang hidup pada era IT akan merasa antusias dengan pembelajaran yang berbasis IT. Pengembangan bahan ajar sangat diperlukan, tanpa terkecuali pada pembelajaran bahasa. Pembelajaran berbasis IT ini dapat diwujudkan dengan penggunaan digital dalam pembelajaran.

Derewianka (dalam Tomlinson, 2003: 199) menegaskan bahwa bahan ajar berbasis digital itu dapat berupa hypermedia, multimedia, dan media komunikasi. Dengan menggunakan bahan ajar berbasis media seperti yang telah dijelaskan sebelumnya, pertama sekali kita akan melihat bagaimana bahan ajar digital dapat meningkatkan keinginan pelajar untuk membaca, menulis, dan akhirnya kita akan melihat bagaimana guru dapat menciptakan lingkungan belajar yang kreatif dan inovatif. Dengan demikian, outcome dari pembelajaran bahasa dan sastra Indonesia benar-benar dirasakan oleh peserta didik.

Berbicara tentang kebutuhan siswa seperti yang telah dijelaskan sebelumnya, pengembangan bahan ajar bahasa dan sastra Indonesia akan lebih bermanfaat jika mengusung tema kearifan lokal. Kearifan lokal tampaknya seperti obat mujarab (panacea) dalam upaya melihat kompleksitas permasalahan yang dihadapi manusia modern akibat perilaku yang tidak rasional dalam menaklukkan alam. Kegagalan manusia modern dalam mengelola kompleksitas permasalahan yang dihadapi memaksanya untuk mencari pilihan-pilihan (alternatives). Pilihan-pilihan tersebut menunjukkan adanya satu jalan buntu dan mungkin dapat pula dikatakan frustasi sehingga memaksanya untuk menengok kembali pada nilai-nilai budaya yang sudah lama mereka tinggalkan dan malahan boleh jadi struktur dan nilai budaya tersebut mungkin pula telah rusak oleh perilaku manusia itu sendiri. Secara sederhana 
kearifan lokal dapat didefinisikan sebagai kebijaksanaan atau nilai-nilai luhur yang terkandung dalam kekayaan budaya lokal. Namun ada kalanya kearifan lokal boleh jadi merupakan slogan “ kembali ke alam" (back to nature) atau natura magistra dan banyak sekali interpretasi yang diberikan oleh para pengguna istilah tersebut seperti halnya juga tentang pengertian kebudayaan.

Dengan mengangkat kearifan lokal dalam bahan ajar, siswa diharapkan dapat mengenali budayanya dan nilai-nilai di dalamnya. Pembinaan karakter yang diajarkan di sekolah juga dapat terlaksana bila siswa memahami betul setiap nilai-nilai budayanya. Hal ini diyakini karena setiap siswa memiliki budaya masing-masing dan budaya tersebut sangat dekat dengan mereka.

\section{B. KAJIAN TEORI}

\section{Konsep Pengembangan Materi}

Banyak orang menghubungkan materi pembelajaran bahasa dengan buku pelajaran karena hal tersebut menjadi cara untuk mempelajari materi. Bagaimanapun, buku ini digunakan oleh guru dan pelajar sebagai fasilitas dalam mempelajari bahasa. Tomlinson (2011: 2) menyatakan bahwa materi ajar seyogiyanya dapat berupa video, DVD, email, youtube, kamus, buku gramatikal, pembaca, LKS atau lembaran latihan yang diperbanyak. Selain itu juga dapat berupa surat kabar, paket makanan, fotografi, bincang-bincang dengan mengundang penutur asli, lembar latihan menulis dalam bentuk kartu atau diskusi antar pelajar. Tomlinson (2011:2) kembali menegaskan bahwa semua hal di atas akan berguna untuk pelajar mengingat bahwa materi dapat menjadi pelajaran dalam memberikan informasi melalui bahasa, semakin menjadikan pelajar terbuka dalam menggunakan bahasa, dapat menjadi pancingan bagi pelajar untuk menstimulus penggunaan bahasa, atau dapat dijadikan fasilitas untuk memecahkan masalah.

'Pengembangan materi merupakan dasar untuk belajar dan sebuah tanggung jawab praktis. Sebagai suatu dasar, materi mempelajari prinsip dan prosedur dalam mendesainnya, implementasi dan evaluasi materi pembelajaran bahasa' (Tomlinson 2001: 66). Sebagai tanggung jawab praktis, materi mengarah pada apapun yang diselesaikan oleh penulis, guru atau pelajar untuk memberikan pengetahuan dalam input bahasa, untuk mengeksploitasi pengetahuan yang maksimal dan untuk menstimulus pencapaian hasil. Dengan kata lain, penerimaan 
informasi tentang pengalaman dari bahasa didesain untuk mempromosikan pembelajaran bahasa (Tomlinson 2001:66).

Para pakar menyatakan bahwa pembelajaran harus didesain berdasarkan kebutuhan peserta didik. Hal ini tentu berkaitan dengan perkembangan zaman. Untuk itu, tentu tidak heran jika banyak para peneliti, baik guru, dosen, maupun mahasiswa memberikan kontribusi dengan menyajikan inovasi, model pembelajaran, media, strategi, dan pendekatan. Pendapat tersebut didiukung oleh Maley (dalam Azarnoosh, 2016: 11) yang mengatakan bahwa materi itu selalu berkembang. Materi merupakan bagian dari seluruh konteks pembelajaran bahasa berdasarkan filosofinya tergantung pada pemikiran untuk apa bahasa itu dan bagaimana orang-orang belajar bahasa sehingga materi tersebut berbeda. Materi itu hanya sebagian kecil dari pembelajaran, namun memiliki peranan yang sangat penting karena materi itu akan digunakan oleh guru, dipelajari oleh siswa, disusun berdasarkan kurikulum dan silabus, ditentukan alokasi waktu dan penilaian hasil pembelajaran, dikaitkan dengan keadan ekonomi dan kebudayaan yang ada di sekitar siswa. Ketika hendak menyusun suatu materi, sering dianggap sebagai sesuatu yang mudah, namun nyatanya memerlukan banyak faktor. Jadi kita tidak dapat memisahkan materi dari permasalahan bahasa dan pembelajaran bahasa.Perkembangan zaman serba teknologi menjadi salah satu contoh perkembangan zaman yang tentu tidak dapat ditepis oleh siapapun. Para pelajar yang hidup pada era IT ini tentu akan merasa lebih tertarik dengan pembelajaran yang berbasis IT. Pengembangan bahan ajar sangat diperlukan dalam hal ini tanpa terkecuali pada pembelajaran bahasa. Pembelajaran berbasis IT ini dapat diwujudkan dengan penggunaan digital dalam pembelajaran. Derewianka (dalam Tomlinson, 2003: 199) menyatakan bahwa bahan ajar digital mengacu pada proses belajar berbasis digital sehingga peserta didik dapat mengakses sumber informasi bahan ajar dengan komputer.

Pembelajaran Digital dapat pula diartikan sebagai sebuah proses pembelajaran yang dilakukan melalui network (jaringan komputer), biasanya lewat internet atau intranet. Dengan fasilitas internet, Pembelajaran Digital tidak tergantung pada pengajar, karena akses informasi (knowledge) lebih luas dan lengkap, sehingga pembelajar dapat belajar kapan saja dan dimana saja.

Dalam teknologi Pembalajaran Digital, semua proses pembelajaran yang biasa didapatkan di dalam sebuah kelas dapat dilakukan secara live namun virtual. Artinya pada saat yang sama seorang pengajar mengajar di depan sebuah komputer yang ada di suatu tempat, 
sedangkan pembelajar mengikuti pembelajaran tersebut dari komputer lain di tempat yang berbeda.

Secara umum terdapat dua persepsi dasar tentang Pembelajaran Digital yaitu: Electronic based e-learning, yaitu pembelajaran yang memanfaatkan teknologi informasi dan komunikasi, terutama perangkat yang berupa elektronik. Artinya, tidak hanya internet, melainkan semua perangkat elektronik seperti film, video, kaset, OHP, Slide, LCD Projector, tape dan lainlain sejauh menggunakan perangkat elektronik.

Internet based, yakni pembelajaran yang menggunakan fasilitas internet yang bersifat online sebagai instrumen utamanya. Dalam hal ini, Pembelajaran Digital bukanlah pembelajaran yang dilakukan secara offline (tanpa jaringan internet), tetapi Pembelajaran Digital adalah pembelajaran yang dilakukan secara online yang harus difasilitasi komputer yang terhubung dengan internet. Artinya pembelajar dalam mengakses materi pembelajaran tidak terbatas jarak, ruang dan waktu, bisa dimana saja dan kapan saja (any where and any time).

Pengembang materi ajar dapat berupa menulis buku teks, menceritakan sebuah cerita, membawa iklan ke kelas, mengekspresikan opini, mencontohkan penggunaan bahasa atau pembacaan puisi. Dengan demikian, guru/ pengembang materi ajar dapat mengetahui bagaiamana membuat prinsip sehingga guru tahu bagiamana bahasa dapat menjadi pembelajaran yang efektif (Tomlinson, 2011:2).

Bila dikaitkan dengan perkembangan zaman dengan kebutuhan siswa, menciptakan suatu pengembangan bahan ajar berupa buku digital merupakan salah satu langkah yang perlu dilakukan oleh guru. Di samping dapat meningkatkan minat belajar siswa, buku digital ini juga dapat membantu siswa dapat berpikir kreatif dan inovatif dalam menciptakan pembelajaran yang efektif.

\section{Prinsip dan Proses Pengembangan Bahan Ajar}

Dalam mengembangkan bahan ajar bahasa Indonesia terdapat beberapa prinsip dan prosedur. Tomlinson (2011: 16) mengatakan bahwa prinsip pengembangan materi ajar, yaitu:

1. Materi harus memberikan dampak.

2. Materi harus membawa kemudahan kepada para pelajar.

3. Materi harus membantu pelajar menjadi percaya diri,

4. Apa yang dipelajari harus berguna dan relevan untuk pelajar. 
5. Materi harus dibutuhkan dan memudahkan pelajar dalam pengembangan diri.

6. Pelajar harus siap untuk memperoleh poin pengajaran.

7. Materi harus mengekspos pelajar untuk menggunakan bahasa secara spontan.

8. Perhatian pelajar harus digambarkan pada tanda-tanda bahasa.

9. Materi harus mengarahkan pelajar pada kesempatan untuk mencapai target bahasa untuk mencapai tujuan komunikasi.

10. Materi harus membawa efek positif pengajaran yang belum diterima.

11. Materi harus disesuaikan dengan gaya belajar pelajar yang berbeda-beda.

12. Materi harus disesuaikan dengan perbedaan pelajar dalam sikap yang efektif.

13. Materi harus mampu membuat siswa hening pada awal pembelajaran.

14. Materi harus memaksimalkan potensi belajar dengan semangat.

15. Materi harus tidak terlalu mengontrol praktik.

16. Materi harus mengarah pada kesempatan pada pengaruh hasil.

Setelah membahas tentang prinsip dalam mengembangan materi ajar, selanjutnya akan dibahas tentang prosedur dalam pengembangan materi ajar. Maley (Azarnoosh, 2016: 21) menjelaskan beberapa prosedur pengembangan materi ajar, yaitu:

\section{Proses Level Macro}

Pada tahap, proses utamanya adalah:

- Desain pada keseluruhan krangka kerja

Bagian ini diambil dari silabus yang dibuat oleh Kementrian Pendidikan (The Common European Framework, Morrow, 2004). Suatu pendekatan telah ditetapkan,kemudian unsur berbeda dikemas akan merincikan materi. Normalnya,beberapa kombinasi dari area pengikut akan menjelaskan lebih spesifik tentang cara pengucapan, kosakata, tata bahasa, fungsi, empat keterampilan berbahasa, tipe teks, berpikir kritis, keterampilan, tema atau topik, situasi/konteks, dan lain-lain. Pada bagian ini penyusun materi akan menyusun dengan baik setiap aktivitas yang digunakannya (bercerita, membaca ekstensif).

- Memilih teks dan aktivitas Pemilihan teks merupakan bagian yang paling utama dalam proses pengembangan materi. Kriteria pemilihannya akan menyangkut tentang ketertarikan intrinsik, relevansi dengan pengalaman pelajar, usia, durasi, kesulitan/kompleksitas linguistik, , kerumitan 
kognitif, kebudayaan, potensi pembelajaran bahasa, daya tarik estetis, dan sesuatu yang paling menaril/memorial.

Hal ini akan menjadi permasalahan seperti hak cipta dan akses terhadap teks. Saat ini menyebarnya ketersediaan materi dalam suatu situs menghapuskan permasalahan tersebut. Para penyusun materi akan membuat dengan jelas nama pembuatan teksnya.

\section{Proses Micro-Level}

a. Hadfield (Azarnoosh, 2016: 22) mengidentifikasi lima tingkatan dalam proses menulis, yaitu:

Tingkat 1: Memilih tipe aktivitas.

Tingkat 2 : Tujuan dan aktivitas yang layak (memastikan aktivitas yang sesuai dengan tujuan yang baik).

Tingkat 3: Penyusunan pemecahan masalah.

Tingkat 4: Menulis materi siswa.

Tingkat 5: Menyusun rubrik prosedur/ penulisan.

b. Maley (Azarnoosh, 2016: 22) menawarkan sebuah peta pembangkit aktivitas. Bagian yang terdiri dari susunan input menggambarkan semua kemungkinan ketersediaan input. Hal ini merupakan proses yang dapat dipalikasikan pada beberapa input. Akhirnya, hasil berkaitan dengan aktivitas seperti pencapaian hasil yang diperoleh.

\section{Tingkat Pengaplikasian}

\section{a. Input/ masukan}

Materi harus menggambarkan sumber manusia yang tak terbatas. Seluruh aktivitas dapat diperkaya oleh pandangan terhadap pelajar. Dalam pemilihan tema/topik, kita harus berangkat dari hal-hal yang umum. Hal itu dapat berupa olahraga, hobi, belanja, festival kebudayaan, dan sebagainya.

Teks

Teks merupakan bagian dasar dari materi. Kita dapat melatih kreativitas melalui pilihan beberapa teks, teristimewa pada yang berkaitan dengan teks sastra, hal itu dapat mengekspos kekreatifan pelajar dalam menggunakan bahasa (Duff \& Malley (Azarnoosh,2016:23)).

b. Proses 
Proses dapat meningkatkan kualitas kreativitas materi. Berikut akan dijelaskan lebih mendetail tentang lima ketegori tingkatan, yaitu:

$\checkmark$ Istilah umum

Penggunaan waktu dapat dihendel dengan kreatif melalui pengaturan waktu yang sesuai dalam beberapa aktivitas (Davis \& Rinvolucri (dalam Azarnoosh, 2016: 25)). Membiarkan siswa banyak melakukan banyak tes, atau dengan melatih siswa mengatur waktunya sendiri sama dengan memunculkan keistimewaan hasil.

$\checkmark$ Manajemen

Kreativitas dalam memanajemen rutinitas dan pengajaran dapat digantikan dengan petunjuk non-verbal. Pelajar dengan cepat akan belajar menggunakan gestur.

\section{c. Hasil}

Input dan proses berkaitan dengan produk hasil tetapi hal itu tidak dapat dihasilkan dengan formula yang kompleks. Hasil pedagogi dapat melewati kepercayaan tradisional dalam tes dan penugasan dalam bentuk portofolio dan jurnal untuk mengevaluasi pelajar (Phuong (Azarnoosh, 2016:26)).

Secara luas, hasil pendidikan muncul dari interaksi kreatif dari input dan proses dan termasuk pula pemahaman tentang kebudayaan, menerima kebijaksanaan atau informasi dengan kritis, mampu memecahkan masalah, dan mampu mengatur waktu dalam mengolah keterampilan. Pada kehidupan sosial, pelajar dapat meningkatkan kepercayaan diri dan lebih bertanggung jawab dan mampu bekerja sama untuk menciptakan suasana belajar yang positif (Hadfield (dalam Azarnoosh, 2016: 27)).

\section{GAGASAN}

Berdsarkan penjelasan di atas, maka dalam rekayasa ini dimuculkan ide yang berkitan dengan pengembangan bahan ajar dan perkembangan zaman. Mengembangkan bahan ajar dalam bentuk buku digital pada masa sekarang ini merupakan pilihan yang tepat dilakukan para guru karena akan membuat siswa lebih tertarik. 
Kebutuhan dalam dunia pendidikan sangatlah kompleks mulai dari kebutuhan sumber ilmu, yaitu buku, guru yang handal, tempat yang memadai, dan kebutuhan penunjang lainnya. $E$ book adalah salah satu alternatif yang cukup baik karena sifatnya yang digital sehingga tidak menggunakan kertas dan hanya memerlukan seperangkat device yang dapat membacanya seperti HP, komputer, laptop, dan device-device lainnya. E-book adalah salah satu bentuk usaha untuk melestarikan literatur berbentuk buku yang banyak jumlahnya dan memerlukan biaya perawatan yang mahal maka untuk dapat melestarikan literatur tersebut hanya dengan melakukan transfer buku ke bentuk E-book.

Dalam E-book terdapat beberapa format buku yang dapat digunakan. E-book ini nantinya akan berupa buku yang di dalamnya terdiri dari video, gambar, teks, audio, animasi, dan evaluasi berupa soal-soal yang menarik berbasis kearifan lokal. Penggunaan Ebook dalam pembelajaran bahasa diduga akan sangat efisien. Hal ini dikarenakan dalam buku tersebut akan dapat ditampilkan keempat keterampilan berbahasa dengan tampilan yang menarik dan ada dalam satu buku. Selain itu, buku ini akan sangat efisien untuk dibawa ke mana saja dan dibaca di mana saja. Buku digital ini akan membuat pelajar lebih mudah memahami teori bahasa, praktik bahasa, dan evaluasi bahasa.

Dengan menggunakan E-book ini , penulis mengharapkan pembelajaran bahasa tidak lagi monoton dan kurang menarik tetapi menjadi ajang untuk pemecah masalah melalui ide-ide yang berkaitan dengan kearifan lokal yang dibahasakan. Hal tersebut sudah sangat sesuai dengan penjelasan dalam kajian teori di atas. Pengembangan bahan ajar harus sesuai dengan kebutuhan siswa dan dapat berbasis digital. Pengembangan bahan ajar berupa E-book ini tentu harus disusun berdasarkan prinsip dan proses pengembangan bahan ajar yang telah dijelaskan sebelumnya.

\section{SIMPULAN}

Materi itu hanya sebagian kecil dari pembelajaran, namun memiliki peranan yang sangat penting karena materi itu akan digunakan oleh guru, dipelajari oleh siswa, disusun berdasarkan kurikulum dan silabus, ditentukan alokasi waktu dan penilaian hasil pembelajaran, dikaitkan dengan kebudayaan yang ada di sekitar siswa. Ketika hendak menyusun suatu materi, seringa dianggap sebagai sesuatu yang mudah, namun nyatanya memerlukan banyak faktor. 
Penggunaan E-book dalam pembelajaran bahasa diduga akan sangat efisien. Hal ini dikarenakan dalam buku tersebut akan dapat ditampilkan keempat keterampilan berbahasa dengan tampilan yang menarik dan ada dalam satu buku. Selain itu, buku ini akan sangat efisien untuk dibawa ke mana saja dan dibaca di mana saja. Buku digital ini akan membuat pelajar lebih mudah memahami teori bahasa, praktik bahasa, dan evaluasi bahasa. Pengembangan bahan ajar menggunakan E-book juga telah sesuai dengan kebutuhan siswa dan dapat berbasis digital. Pengembangan bahan ajar berupa $E$-book ini tentu harus disusun berdasarkan prinsip dan proses pengembangan bahan ajar yang telah dijelaskan sebelumnya.

\title{
DAFTAR RUJUKAN
}

Azarnoosh, Maryam. 2016. Issues in Materials Development. Rotterdam:Sense Publishers.

Tomlinson, Brian. 2011. Materials Development in Language Teaching. UK: Cambridge University Press.

. 2014. Developing Materials for Language Teaching. London: Bloomsbury.

Widiasworo, Erwin. 2017. Inovasi Pembelajaran Berbasis Life Skill dan Entrepreneurship. Yogyakarta: Ar-Ruzz Media.

\section{ANALISIS PEMBIASAAN PERILAKU BERLITERASI DALAM UPAYA PENINGKATAN KARAKTER OLEH SISWA KELAS VIII-2 SMP ST. IGNASIUS MEDAN}

\author{
Maria Kartika Nababan \\ Pendidikan Bahasa Indonesia \\ Pascasarjana Universitas Negeri Medan \\ maria.kartika08@gmail.com
}




\begin{abstract}
Abstrak
Literasi memiliki makna dan implikasi dari keterampilan membaca dan menulis dasar ke pemerolehan dan manipulasi pengetahuan melalui teks tertulis, dari analisis metalinguistik unit gramatikal ke struktur teks lisan dan tertulis. Dari beberapa lembaga survey tersebut Indonesia menempati urutan bawah dan itu menunjukkan bahwa kemampuan literasi di Indonesia masih rendah. Riset ini bertujuan untuk mengetahui kemampuan literasi siswa di SMP St. Ignasius dan mengetahui strategi yang tepat untuk meningkatkan kemampuan literasi siswa. Pengumpulan data secara eksklusif dilakukan pada kelas VIII-2 dengan jumlah siswa 30 orang. Riset ini dimulai dari bulan Agustus sampai Oktober 2018. Hasil mini riset ini bahwa perpustakaan mini kelas efisien untuk pembiasaan membaca siswa. Kemudian, dapat dilihat bahwa siswa pada dasarnya memiliki keinginan untuk membaca meskipun ada yang membaca hanya sekilas dan melihat judul terlebih dahulu. Hal tersebut dapat diatasi apabila guru tetap rutin memperhatikan kegiatan membaca siswa sampai akhirnya ia terbiasa dengan kegiatan membaca. Dengan demikian dapat disimpulkan bahwa siswa SMP St.Ignasius Medan masih berada pada tahap pembiasaan membaca.
\end{abstract}

Kata kunci: buku, literasi, siswa, perpustakaan mini, sekolah

\title{
A. PENDAHULUAN
}

Istilah "literasi" memiliki makna meluas dari waktu ke waktu. Literasi sekarang tidak hanya diartikan sebagai kemampuan menulis dan membaca tetapi "... has instead come to be considered synonymous with its hoped-for consequences" (Aronoff,1995: 68). Kini, literasi memiliki makna dan implikasi dari keterampilan membaca dan menulis dasar ke pemerolehan dan manipulasi pengetahuan melalui teks tertulis, dari analisis metalinguistik unit gramatikal ke struktur teks lisan dan tertulis, dari dampak sejarah manusia ke konsekuensi filosofis dan sosial pendidikan barat (Goody \& Watt, 1963; Chafe \& Danielewicz, 1987; Olson, 1991; Ong, 1992). Bahkan perubahan evolusi manusia merupakan dampak dari pemikiran literasi (Donald, 1991).

Beberapa survei literasi yang diikuti Indonesia antara lain PIRLS dan PISA. PIRLS (Progress in International Reading Literacy Study) adalah studi internasional tentang literasi membaca untuk siswa sekolah dasar (kelas IV) yang dikoordinasikan oleh IEA (The International Association for the Evaluation of Educational Achievement, berkedudukan di Amsterdam, Belanda). Dari beberapa lembaga survey tersebut Indonesia menempati urutan bawah dan itu menunjukkan bahwa kemampuan literasi di Indonesia masih rendah. Khusus untuk kompetensi membaca,subskala yang dipakai adalah kemampuan 
siswa dalam memeroleh informasi (retrieving information), menginterpretasi teks (interpreting text), dan merefleksikan teks (reflecting text).

Deklarasi Praha (2003) menyebutkan bahwa literasi mencakup bagaimana seseorang berkomunikasi dalam masyarakat. Literasi juga bermakna praktik dan hubungan sosial yang terkait dengan pengetahuan dan budaya. Melalui kegitan literasi, karakter siswa diperkuat melalui harmonisasi olah hati, olah rasa, olah pikir, dan olah raga dengan dukungan pelibatan publik dan kerja sama antara sekolah, keluarga, dan masyarakat. Kegiatan gemar membaca adalah kebiasaan menyediakan waktu untuk membaca dan berbagi bacaan yang memberikan kebijakan bagi dirinya atau berbagi informasi. Maka melalui kegiatan literasi, siswa diharapkan mampu mengembangkan kemampuan dan watak serta peradaban bangsa yang bermartabat dalam rangka mencerdasakan kehidupan bangsa serta mengembangkan potensi siswa agar menjadi manusia yang bertakwa pada Tuhan Yang Maha Esa, berakhlak mulia, sehat, berilmu, cakap, kreatif, mandiri, dan menjadi warga negara yang demokratis dab bertanggung jawab.

Kajian mengenai literasi di tingkat SMP tidak dapat dipisahkan dari survei kompetensi literasi, yaitu aspek literasi yang diukur adalah memahami, menggunakan, merefleksikan, dan mencipta dalam bentuk tulisan. Untuk sampai pada tahap mencipta sesuatu, siswa harus memiliki minat baca. Namun, minat baca pada siswa masih dapat dikategorikan rendah, khususnya siswa di SMP St. Ignasius. Serangkaian upaya telah dilakukan oleh sekolah untuk mendukung kegiatan literasi di sekolah, hanya saja belum menunjukkan hasil yang signifikan. Untuk itu, pada mini riset ini akan diidentifikasi perilaku membaca siswa SMP agar guru dapat memahami kebutuhan siswa dalam membaca. Riset ini akan dilakukan di kelas VIII-2 SMP St. Ignasius Medan.

Berdasarkan pemaparan tersebut, maka mini riset ini membuat suatu hipotesis sebagai berikut.

1. Perilaku membaca siswa berpengaruh pada upaya peningkatan karakter berpikir kritis melalui kegiatan literasi siswa.

2. Strategi dibutuhkan untuk meningkatkan literasi di sekolah-sekolah khususnya SMP St. Ignasius. Riset mini ini bertujuan untuk :

1. Mengetahui kemampuan literasi siswa di SMP St. Ignasius.

2. Mengetahui strategi yang tepat untuk meningkatkan kemampuan literasi siswa.

\section{B. METODE PENELITIAN}


Dalam riset mini ini akan dilakukan pengumpulan data dengan cara meneliti kegiatan literasi siswa SMP. Adapun data narasumber adalah sebagai berikut.

Kelas $\quad:$ VIII-2

Sekolah $\quad$ : SMP St. Ignasius Medan, Jalan Karya Wisata No. 6 Medan Johor

Riset ini akan menjawab pertanyaan tentang bagaimana perilaku membaca siswa SMP dan apa strategi yang dapat diambil untuk meningkatkan minat baca siswa. Kemudian, membuktikan hipotesis bahwa ada keterkaitan perilaku membaca siswa dengan pemilihan strategi peningkatan kemampuan literasi siswa dan kegiatan literasi sekolah merupakan cara efektif sebagai upaya meningkatkan minat baca siswa. Kegiatan literasi dengan menggunakan perpustakaan mini ini telah dilakukan di beberapa kelas di SMP St.Ignasius, seperti kelas VIII-1, VIII-2, VIII-3, dan IX-2. Namun, pengumpulan data secara eksklusif dilakukan pada kelas VIII-2 dengan jumlah siswa 30 orang dengan membuat daftar nama peminjam buku mulai dari bulan Agustus sampai Oktober 2018. Dari daftar tersebut ditemukan beberapa kebiasaan membaca siswa.

Rangkaian kegiatan yang dilakukan adalah sebagai berikut.

1. Siswa diminta untuk membawa buku yang mereka sukai, kecuali novel dan komik, 1 buku per siswa pada awal bulan Agustus

2. Siswa mengumpulkan buku-buku tersebut dan membuat perpustakaan mini di kelas.

3. Guru memilih 3 orang penanggung jawab perpustakaan mini di kelas.

4. Siswa penanggung jawab perpustakaan mini membuat daftra nama peminjam buku yang akan diisi secara rutin, ketika siswa meminjam buku dari perpustakaan mini.

5. Siswa dan guru membuat kesepakatan dalam menggunakan perpustakaan mini kelas, seperti lamanya waktu peminjaman, konsekuensi bagi yang tidak mengembalikan buku tepat waktu, dsb.

6. Siswa bebas meminjam buku di jam istirahat atau di luar waktu literasi dan jam pelajaran.

7. Guru akan memeriksa daftar buku di kelas secara rutin setiap 2 minggu sekali.

Rangkaian kegiatan tersebut dilakukan dengan rutin setiap harinya, khususnya hari Kamis, Jumat, dan Sabtu karena sekolah menjadikan hari tersebut sebagai hari literasi.

\section{HASIL DAN PEMBAHASAN}

Mini riset ini berangkat dari permasalahan literasi di Indonesia yang dilihat dalam hasil survey beberapa lembaga survey yang diikuti oleh Indonesia. Menurut hasil survey tersebut ternyata Indonesia 
menempati posisi yang dapat dikatakan buruk karena ada pada peringkat bawah. Kementerian Pendidikan dan Kebudayaan telah berupaya dengan membuat kebijakan terkait dengan budaya membaca. Kebijakan tersebut diantaranya adalah Peraturan Menteri Pendidikan dan Kebudayaan Nomor 23 Tahun 2015 tentang Penumbuhan Budi Pekerti, salah satunya, mengenai kegiatan membaca buku nonpelajaran selama lima belas menit sebelum waktu belajar dimulai.

Kegiatan tersebut adalah upaya menumbuhkan kecintaan membaca kepada peserta didik dan pengalaman belajar yang menyenangkan sekaligus merangsang imajinasi. Sebagai turunan peraturan menteri tersebut telah di sosialisasikan pula pada seluruh sekolah di Indonesia tentang Gerakan Literasi Sekolah meliputi 3 tahapan yakni: 1) penumbuhan minat baca, 2) meningkatkan kemampuan literasi buku pengayaan dan 3) meningkatkan kemampuan literasi buku pelajaran (Kemdikbud, 2016).

Setelah melalukan rangkaian kegiatan di atas, pada bulan Oktober, data yang diperoleh diperoleh dari penelitian tersebut, yakni:

Pembiasaan Membaca Siswa

Membawa buku

\begin{tabular}{|c|l|}
\hline \multicolumn{1}{|c|}{ Bulan } & \multicolumn{1}{|c|}{ Jumlah Buku yang Dibawa Siswa } \\
\hline Agustus & \\
\hline Minggu 1 & 24 buku \\
\hline Minggu 3 & 33 buku \\
\hline September & 28 buku \\
\hline Minggu 1 & 30 buku \\
\hline Minggu 2 & \\
\hline Oktober & 30 buku \\
\hline Minggu 1
\end{tabular}

Tabel 1. Jumlah buku yang di bawa siswa

Berdasarkan data di atas terlihat adanya perubahan jumlah buku yang di bawa oleh siswa. Adapun penyebab adanya perubahan jumlah buku ini, antara lain:

\section{Agustus}

- Minggu ke-1: Siswa tidak memiliki buku, selain komik dan novel ataupun buku-buku milik orang tua di rumahnya. Kemudian guru kembali memberi motivasi oleh siswa terkait kegiatan literasi. 
- Minggu ke-2 : Pada minggu ke-2, seluruh siswa telah memiliki buku masing-masing dan ada siswa yang membawa buku lebih dari satu. Hal itu yang menyebabkan jumlah buku pada minggu ke-2 Oktober mencapai jumlah 33 buku. Hal ini menunjukkan perkembangan yang baik.

\section{September}

- Minggu ke-1 : Jumlah buku di perpustakaan mini kelas VIII-2 mengalami penurunan. Hal ini disebabkan adanya siswa yang membaca buku dan membawanya pulang kemudian lupa membawanya kembali ke sekolah.

- Minggu ke-2 : Jumlah buku bertambah sejumlah siswa di kelas karena siswa telah membawa kembali buku bacaannya ke sekolah.

\section{Oktober}

- Minggu ke-1 : Buku masih pada jumlah yang sama dengan minggu ke-2 November, yakni sejumlah 30 buku.

\section{Perilaku Membaca Siswa}

\begin{tabular}{|l|l|l|l|}
\hline Perilaku membaca siswa & \multicolumn{1}{|c|}{ Agustus } & \multicolumn{1}{|c|}{ September } & \multicolumn{1}{|c|}{ Oktober } \\
\hline Membaca serius & $100 \%$ & $66,6 \%$ & $33 \%$ \\
\hline $\begin{array}{l}\text { Membaca karena tugas/ } \\
\text { hari literasi/ diwajibkan }\end{array}$ & $100 \%$ & $90 \%$ & $90 \%$ \\
\hline Membaca dan mencatat & $100 \%$ & $66,6 \%$ & $16,6 \%$ \\
\hline Menanya makna kata & $16,6 \%$ & $16,6 \%$ & $6,6 \%$ \\
\hline Membaca sekilas & $0 \%$ & $0 \%$ & $33 \%$ \\
\hline Membaca melihat judul & $0 \%$ & $33 \%$ & $33 \%$ \\
\hline
\end{tabular}

Tabel 2. Perilaku membaca siswa 


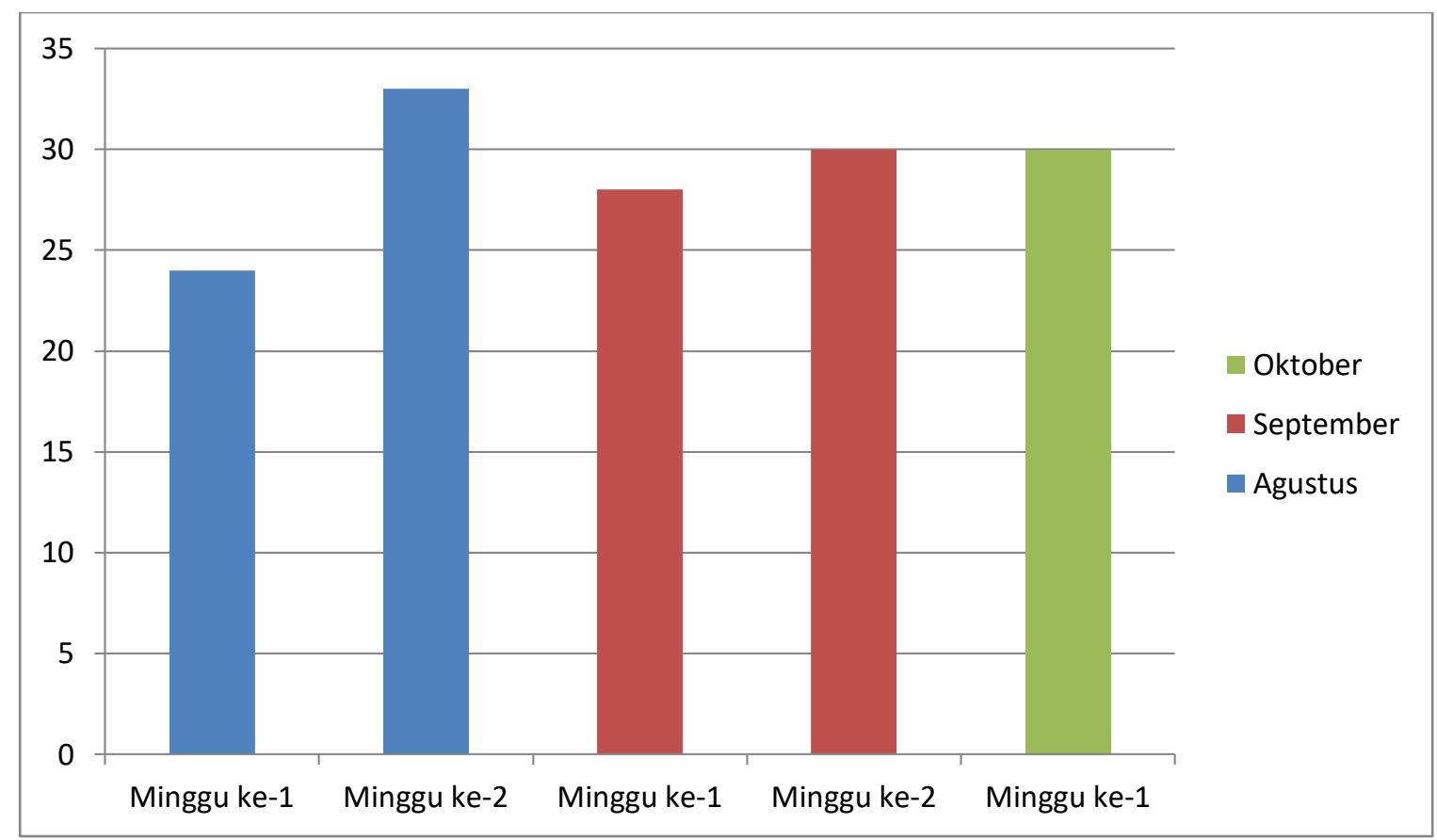

Grafik 1. Siswa yang membawa buku

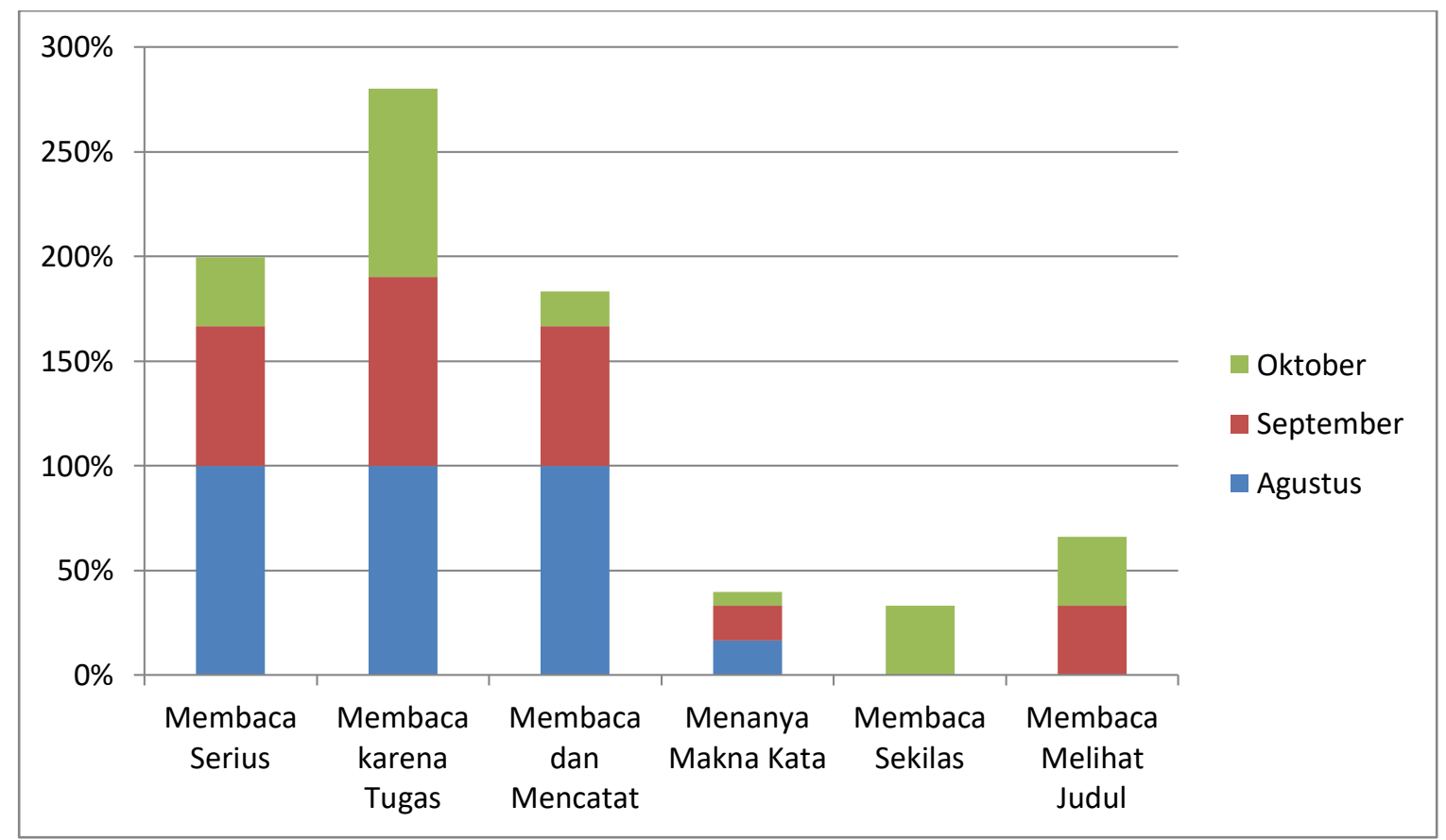

Grafik 2. Perilaku membaca siswa (dalam \%)

Berdasarkan data di atas diperoleh hasil bahwa upaya pembiasaan kegiatan membaca siswa dilihat dari antusias siswa membawa buku ke sekolah untuk dijadikan buku di perpustakaan mini kelas 
menunjukkan peningkatan. Hal itu dapat dilihat dari jumlah buku yang meningkat dari minggu ke-1 bulan Agustus (awal kegiatan pembiasaan) dan meningkat pada minggu ke-2. Namun, kembali mengalami penurunan pada minggu ke 1 bulan September. Hal ini dikarenakan siswa merasa tertarik dengan buku bacaan sehingga siswa membawa buku dari perpustakaan mini ke rumah dan dibaca di rumah. Selanjutnya, jumlah buku pada minggu berikutnya hingga akhir riset ini menunjukkan jumlah yang tetap, yakni 30 buku (sebanyak jumlah siswa). Data pembiasaan kegiatan membaca siswa dengan membawa buku kesukaan untuk dijadikan buku di perpustakaan mini kelas ternyata memberikan dampak yang baik bagi perkembangan minat baca siswa.

Selanjutnya pada grafik 2, dapat dilihat bagaimana perilaku membaca siswa. Meskipun pada grafik 1 dijelaskan bahwa siswa mulai terbiasa dengan buku dan mulai tertarik dengan buku. Namun pada grafik 2 persentase jumlah siswa yang membaca serius setiap bulannya mengalami penurunan. Begitu pula perilaku membaca dan mencatat, menanya makna kata. Kemudian pada perilaku membaca siswa, yaitu membaca sekilas dan membaca melihat judul meningkat per bulannya. Siswa terlihat begitu antusias membaca hanya di saat guru memberikan kegiatan wajib baca untuk mengerjakan tugas ataupun saat hari literasi. Namun, pada bulan September dan Oktober, jumlah siswa yang membaca karena tugas/ hari literasi menurun karena adanya siswa yang tidak hadir. Untuk melihat siswa membaca dengan serius dan mencatat bacaannya hingga menemukan kata-kata sulit akan jarang ditemukan di luar hari literasi ataupun proses pengerjaan tugas.

Berdasarkan data-data di atas, dapat dilihat keefisienan perpustakaan mini kelas terhadap pembiasaan membaca siswa. Kemudian, dapat dilihat bahwa siswa pada dasarnya memiliki keinginan untuk membaca meskipun ada yang membaca hanya sekilas dan melihat judul terlebih dahulu. Hal tersebut dapat diatasi apabila guru tetap rutin memperhatikan kegiatan membaca siswa sampai akhirnya ia terbiasa dengan kegiatan membaca. Ini dikarenakan jumlah siswa yang membaca buku ketika diwajibkan oleh guru sangat tinggi jumlahnya. Dengan demikian, pembiasaan membaca siswa yang dilakukan di kelas VIII-2 SMP St. Ignasius Medan berjalan dengan baik, khususnya pada hari-hari literasi yang ditentukan oleh sekolah. Untuk itu, guru hendaknya mencari strategi lain untuk membantu siswa terbiasa dengan kegiatan membaca dan mengubah perilaku membacanya.

\section{SIMPULAN}

Persoalan rendahnya budaya membaca dan rendahnya kemampuan literasi siswa tidak perlu diratapi apalagi sibuk mencari pihak yang bersalah. Jalan yang terbaik adalah masing-masing komponen bangsa Indonesia menjalankan perannya masing-masing dan memberikan solusi nyata untuk mengatasi 
akar permasalahan tersebut. Menentukan strategi yang tepat adalah langkah utama yang harus dikembangan oleh guru dan pihak sekolah.

Pembiasaan membaca siswa yang dilakukan di kelas VIII-2 SMP St. Ignasius Medan berjalan dengan baik, khususnya pada hari-hari literasi yang ditentukan oleh sekolah. Sehingga sekolah perlu menindaklanjuti program literasi di sekolah dengan mencari strategi-strategi lainnya. Penentuan strategi itu akan lebih mudah ketika pihak sekolah sudah mengetahui perilaku membaca siswa. Dengan taraf literasi siswa yang masih sampai pada taraf pembiasaan literasi, belumlah menunjukkan taraf yang memungkinkan untuk siswa mengembangkan karakter seperti yang diharapkan pada penjelasan di atas. Untuk itu sunggu dibutuhkan strategi lain dalam peningkatan taraf literasi siswa.

\section{DAFTAR PUSTAKA}

Aronof, M. 1994. Spelling and culture.Dalam W.C. Watt (Ed). Writing system and cognition, Dordrecht: Kluwer.

Benson, V. 2002. Shifting paradign and pedagogy with nonfiction: A call to arms for survival in the 21st century. The New England Reading Association Journal, 38, 1-6. Diunduh pada 15 Maret 2013. http://www.proquest/umi/pqd.web

Chafe, W. 1994. Discourse, consciusness, and time. Chicago: The University of Chicago Press. Cladwell, J. S. (2008). Comprehension assessment: A classroom guide. New York: Th

Donald, M. 1991. Origins of the modern mind: three stages in the evolution of culture and cognition. Cambridge MA: Harvard University Press.

Goody, J. \& Watt, I. 1963. The consequences of literacy. Contemporary Studies in Society and History 5 , Diunduh pada 15 Maret 2013 http://www.proquest/ umi/pqd.web

Kemdikbud, 2016. Manual Pendukung Pelaksanaan Gerakan Literasi Sekolah untuk Jenjang SMP. Jakarta: Dirjen Dikdasmen.

Ong, W.J. 1992. Writing is a technology that restructures thought. Dalam

P.Downing, S.D. Lima \& M. Noonan (Eds). The Linguistics of literacy. Amsterdam: John Benjamins.

UNESCO. (2007). Education for all by 2015: Will we make it? EFA global monitoring report 2008. UK: Oxford University Press. 


\title{
PENGEMBANGAN BAHAN AJAR BAHASA INDONESIA BERBASIS KEARIFAN LOKAL LABUHANBATU UTARA BERDASARKAN KURIKULUM 2013 YANG DISEMPURNAKAN UNTUK SMA KELAS X DI KECAMATAN NA.IX-X
}

\author{
Nining Mindayani \\ Mahasiswa Magister Pendidikan Bahasa Indonesia Unimed
}

\begin{abstract}
Abstrak: Bahan ajar bahasa Indonesia berbasis kearifan lokal secara teknikal dan subtansial mewarnai berbagai komponen di dalam setiap teks yang akan disajikan kepada peserta didik sebagai tujuan pengenalan nilai-nilai lokal yang arif sebagai upaya pembentukan karakter. Penggunaan tema budaya lokal Labuhanbatu Utara lebih tepat digunakan dalam materi pembelajaran bahasa Indonesia SMA kelas $X$. Pandangan ini mengacu pada Kurikulum 2013 yang menyebutkan bahwa lingkup interaksi, dan ranah sikap untuk SMA di dalam Kurikulun 2013 difokuskan dalam jangkauan pergaulan dan keberadaannya, secara logis pemilihan jenjang sangat sesuai, tertera di dalam Kurikulum dijelaskan bahwa lingkup interaksinya dalam pergaulan dunia. Penelitian ini bertujuan untuk (1) mendeskripsikan langkah pengembangan bahan ajar bahasa Indonesia berbasis budaya lokal Malang berdasarkan Kurikulum 2013 yang disempurnakan untuk SMA kelas X di kecamatan NA.IX-X Kabupaten Labuhanbatu Utara, (2) mendeskripsikan ketepatan pengembangan bahan ajar bahasa Indonesia berbasis kearifan lokal Labuhanbatu Utara berdasarkan Kurikulum 2013 yang disempurnakan untuk SMA kelas X di kecamatan NA.IX-X. Metode pengembangan bahan ajar berbasis kearifan lokal ini dikembangkan sesuai dengan model 4D. Tahap-tahap pengembangan bahan ajar ini meliputi: (1) tahap pendefinisian (define), (2) tahap perancangan (design), (3) tahap pengembangan (develop), dan (4) tahap penyebaran (dessiminate). Pada tahap penyebaran tidak dilakukan oleh peneliti. Adapun subjek penelitian adalah siswa kelas X SMA di kecamatan NA.IX-X. Kelayakan bahan ajar sesuai dari hasil analisis oleh validasi ahli bahasa dan isi, validasi ahli media dan perancangan, validasi praktisi, dan respon siswa.
\end{abstract}

Kata Kunci: pengembangan, bahan ajar, berbasis kearifan lokal

\section{PENDAHULUAN}

Dalam Kurikulum 2013 ada perubahan yang sangat mendasar untuk mata pelajaran bahasa Indonesia, yaitu digunakannya pendekatan pembelajaran berbasis teks. Perubahan ini membawa konsekuensi tidak hanya pada proses pembelajaran, tetapi juga pada materi pembelajaran. Selain itu, dalam implementasi Kurikulum 2013 bahasa Indonesia juga ditetapkan sebagai penghela ilmu pengetahuan (carrier of knowledge). Fungsi ini menjadikan bahasa sebagai alat untuk mempercepat berkembangnya penguasaan ilmu pengetahuan siswa yang seiring dan seirama dengan perkembangan kemampuan berbahasa. Kemahiran menguasai makna dan struktur bahasa Indonesia sekaligus menjadi kekayaan pengetahuannya. Sebagai suatu inovasi yang sedang disemaikan, perjalanan Kurikulum 2013 ini pasti tidak akan serta-merta berjalan secara sempurna. Oleh karena itu, dalam upaya mensukseskan pelaksanaan Kurikulum 2013 upaya perbaikan yang berkelanjutan dalam pengelolaan Kurikulum di sekolah pengembangan bahan ajar dan peraktik pembelajaran di sekolah menjadi penting. Salah satu pengembangan bahan ajar dapat berupa pengembangan buku pembelajaran yang dapat meningkatkan keingintahuan, dan memberi informasi baru, buku pembelajaran ini juga diharapkan dapat membantu siswa dalam memahami dan memaknai suatu konsep terutama konsep bahasa Indonesia pada kelas X. 
Semua itu, dilakukan agar menghasilkan bahan ajar yang layak secara empiris dan juga dapat membantu siswa dalam proses pembelajaran, sehingga siswa dapat belajar dengan maksimal untuk mencapai kompetensi sesuai dengan Kurikulum 2013.

Meningkatkan kualitas proses dan hasil belajar salah satunya dapat ditopang dengan keberadaan bahan ajar, karena bahan ajar merupakan salah satu faktor penentu keberhasilan pembelajaran. Dengan bahan ajar yang didesain secara bagus dan dilengkapi berbagai gambar, warna, bahkan ilustrasi yang menarik akan menstimulus siswa untuk memanfaatkan bahan ajar secara maksimal. Bahan ajar merupakan bahan belajar yang digunakan dalam aktivitas pembelajaran di kelas demi tercapainya tujuan pembelajaran. Prastowo (2013:17) menjelaskan bahwa bahan ajar merupakan segala bahan (baik informasi, alat maupun teks yang disusun secara sistematis dan menampilkan sosok utuh dari kompetensi yang akan dikuasai siswa serta digunakan dalam proses pembelajaran. Misalnya, buku teks, modul, handout, LKS, model, bahan audio, dan bahan ajar interaktif.Bahan ajar dalam wujud buku teks merupakan sarana belajar yang praktis karena menyajikanmateri dalam bentuk unitunit pembelajaran. Pada prinsipnya, buku teks disusun atas kebutuhan pembelajaran yang diperlukan siswa yang dikemas dalam unit-unit kegiatan yang spesifik dan sistematis dengan berpedoman pada Kurikulum (Lestari, 2013:2-3). Dalam konteks mengisi peran pendidikan karakter dalam pembelajaran bahasa Indonesia di sekolah, kearifan lokal merupakan opsi yang tepat guna memediasi penanaman karakter melalui bahan ajar. Kebudayaan dan pendidikan merupakan bagian yang tak dapat dipisahkan. Laksana dua sisi mata uang keduanya satu kesatuan dan saling mendukung, serta saling menguatkan. Kebudayaan menjadi falsafah pendidikan, sementara pendidikan menjadi penjaga utama kebudayaan, karena peran pendidikan membentuk orang menjadi berbudaya (Wibowo dan Gunawan, 2015:12-13).

Apakah bahasa dan sastra memiliki peran dalam pembentuk karakter? Pendidikan karakter dapat digali dari bahasa dan sastra. Artinya, bahasa dan sastra memiliki fungsi dan peran dalam pendidikan karakter sejalan dengan visi pembangunan nasional Dalam karya sastra, nilai karakter dapat dikenali atau diakses asal pembaca sastra memiliki paradigma bahwa karya sastra memberikan manfaat atau fungsi sebagai dulce dan utile 'menyenangkan' dan

'berguna'. Pengertian menyenangkan harus dimaknai bahwa karya sastra tidak dimaksudkan untuk memaksa pembaca mengikuti pemikiran pengarang. Akan tetapi, karya sastra memberikan hiburan rohani karena pengungkapannya yang khas, rileks, alternatif, dan tidak dominatif. Sementara itu, berguna harus dikaitkan dengan fungsi sastra yang memberi pencerahan pemikiran kepada pembaca. Oleh sebab itu, nilai subtansi kualitas karya sastra, salah satunya, terletak pada aspek kebaruan atau aktualitas gagasan yang diungkapkan oleh pengarang, baik melalui media karya puisi, cerpen, novel, dan drama, dalam rangka memberi pencerahan pemikiran kepada pembaca.

Posisi kearifan lokal dalam pembelajaran bahasa dan penguatan karakter sangat penting. Pada era komunikasi canggih sekarang ini diperlukan kecerdasan memanfaatkan dan mengemas nilai-nilai kearifan lokal dalam konteks global. Di samping itu, tidak kalah penting adalah hadirnya kreativitas untuk menghadirkan kembali rasa percaya diri dalam berperilaku lokal dalam komunikasi nasional dan global. Sudah barang tentu penafsiran dan kreativitas pengarang sastra menjadi kebutuhan pokok. Kondisi itu disadari oleh pengarang masa kiri yang memiliki trend untuk menghadirkan karya sastra dari sumber sastra tradisi dalam formal sastra modern. Kondisi itu dapat dimaknai sebagai kerinduan sekaligus pengakuan bahwa nilai lokal masih layak dimanfaatkan dalam mendukung pembentukan karakter global. Pendidikan budaya dan karakter bangsa merupakan pendidikan yang mengembangkan 
nilainilai budaya dan karakter bangsa pada diri peserta didik sehingga memiliki nilai dan menerapkan nilai-nilai tersebut dalam kehidupannya sehingga menjadi anggota masyarakat dan warga negara yang religius, nasionalis, produktif dan kreatif. Saat ini, berbagai daerah di Indonesia dihadapkan dengan keterancaman budaya lokal oleh modernisasi. budaya lokal yang secara umum menyandang sifat tradisional acapkali membuatnya tidak mampu bertahan dalam jeramnya arus modernisasi. Parahnya ada pandangan masyarakat yang beranggapan bahwa kearifan lokal adalah budaya primitif, sehingga menjadikan masyarakat alergi dengannya. Padangan-pandangan seperti ini tentu akan mempercepat punahnya budaya lokal yang sebenarnya syarat akan nilai. Oleh karena itu, upaya-upaya untuk melestarikan budaya lokal perlu dirancang dan dilaksanakan dalam berbagai bentuk, salah satunya dengan mengintegrasikannya ke dalam aktivitas pembelajaran di sekolah.

Menurut Latif (dalam Wibowo dan Gunawan: 2015) pendidikan karakter mestinya berbasis pada budaya sendiri, yaitu berupa penggalian nilai-nilai luhur yang ada dalam kearifan lokal. Seperti kita ketahui, setiap daerah di Indonesia memiliki kearifan lokal. Maka nilai-nilai karakter yang diinternalisasikan melalui karakter sebaiknya diambilkan melalui nilai-nilai luhur dari masing-masing budaya lokal. Penggalian nilai-nilai kearifan lokal sebagai dasar sebagai basis pendidikan karakter ini, juga sejalan dengan rekomendasi UNESCO tahun 2009. Menurut UNESCO, penggalian kearifan lokal sebagai dasar pendidikan karakter dan pendidikan pada umumnya, akan mendorong timbulnya sikap saling menghormati antar etnis, suku, bangsa, dan agama, sehingga keberagaman terjaga.

Bahan ajar bahasa Indonesia berbasis kearifan lokal Labuhanbatu Utara secara teknikal dan subtansial mewarnai berbagai komponen di dalam setiap teks yang akan disajikan kepada peserta didik sebagai tujuan pengenalan nilai-nilai lokal labuhanbatu utara yang arif sebagai upaya pembentukan karakter. Penggunaan tema budaya lokal labuhanbatu utara lebih tepat digunakan dalam materi pembelajaran bahasa Indonesia kelas X SMA. Pandangan ini mengacu pada Kurikulum 2013 yang menyebutkan bahwa lingkup interaksi, dan ranah sikap untuk SMA di dalam Kurikulun 2013 difokuskan dalam jangkauan pergaulan dan keberadaannya, secara logis pemilihan jenjang sangat sesuai apabila dibandingkan dengan jenjang SMA yang di dalam Kurikulum dijelaskan bahwa lingkup interaksinya dalam jangakauan pergaulan dunia. Berdasarkan Pengembangan buku bahan ajar oleh Ahmad Syukron pada tesisnya yang berjudul Pengembangan Bahan Ajar Teks Deskripsi Berbasis Kearifan Lokal untuk SMP di Jember, Pascasarjana, Universitas Negeri Malang, Program Studi Pendidikan Bahasa Indonesia pada (Juni 2015), menyatakan bahwa hasil validasi lembar angket telaah dosen dan guru menunjukkan respon positif siswa terhadap bahan ajar yang dikembangkan berbasis kearifan lokal.

Berdasarkan hal tersebut, maka peneliti ingin mengembangkan bahan ajar pembelajaran Bahasa Indonesia pada siswa kelas X SMA NA.IX-X. Materi ajar yang dikembangkan tetap mengacu pada buku pedoman dari Kemendikbud berdasarkan kurikulum 2013 yang disempurnakan, hanya saja produk yang dikembangkan ini berupa buku pembelajaran bahasa Indonesia berbasis kearifan lokal Labuhanbatu Utara. Perbedaan penelitian sebelumnya dan penelitian ini selain setting penelitian, pada tesis ini peneliti tidak hanya berfokus pada satu teks, tetapi satu semester yang terdiri dari lima teks pembahasan, yaitu teks laporan hasil observasi, teks prosedur kompleks dan teks eksposisi, teks anekdot, dan teks negosisasi sesuai dengan target Kurikulum 2013 yang telah disempurnakan. Maka dari itu, peneliti mengembangkan bahan ajar yang berjudul Pengembangan Bahan Ajar Bahasa Indonesia Berbasis Kearifan Lokal Labuhanbatu Utara Berdasarkan Kurikulum 2013 yang Disempurnakan untuk SMA kelas $X$ di Kecamatan Na.IX-X. Fokus penilitian ini bertujuan (1) mendeskripsikan langkah pengembangan bahan ajar bahasa Indonesia berbasis Kearifan Lokal Labuhanbatu Utara berdasarkan 
Kurikulum 2013 yang disempurnakan untuk SMA kelas X di Kecamatan Na.IX-X, dan (2) mendeskripsikan ketepatan pengembangan bahan ajar bahasa Indonesia berbasis Kearifan Lokal Labuhanbatu Utara berdasarkan Kurikulum 2013 yang disempurnakan untuk SMA kelas X di Kecamatan Na.IX-X.

\section{METODE PENGEMBANGAN}

Model pengembangan yang digunakan dalam pengembangan bahan ajar berbasis Kearifan Lokal Labuhanbatu Utara ini adalah model pengembangan prosedural yang diadaptasi dari model pengembangan 4-D. Model ini terdiri dari empat tahap pengembangan yaitu define, design, develop, dan disseminate (Trianto, 2012:190). Model pengembangan 4-D terdiri dari empat tahap pengembangan, yaitu define, design, develop, dan disseminate atau diadaptasikan menjadi model 4-P (model 4 P), yaitu pendefinisian, perancangan, pengembangan, dan penyebaran. (al- Tabany, 2015: 232233).

Dengan berbagai keterbatasan, di sini peneliti membatasi pengembangan perencanaan pembelajaran dalam penelitian ini hanya sampai pada tahap pengembangan, untuk tahap penyebaran tidak dilakukan oleh peneliti. Prosedur pengembangan seperti yang telah dipaparkan sebelumnya, model pengembangan 4D memiliki 4 tahapan, yaitu, (1) penetapan yang terdiri dari analisis (a) analisis tujuan, (b) analisis kelas, (c) telaah kurikulum, (d) telaah buku teks, (e) telaah teori, dan (f) spesifikasi produk, (2) perancangan yang terdiri dari (a) mengumpulkan materi bahan ajar, (b) mengolah teks, (c) mengonsep bahan ajar, dan (d) menyusun bahan ajar,(3) pengembangan yang terdiri dari (a) validasi ahli, (b) validasi praktisi, dan (c) uji coba produk (4) penyebarluasan yang terdiri dari (a) uji efektivitas dan (b) pencetakan.

Dalam penelitian dan pengembangan ini, analisis datanya berupa data verbal dan data numeral. wawancara dan catatan validator dalam angket yang diberikan. Untuk data numeral tentu di dapatkan dari hasil kuantifikasi terhadap angket yang diberikan kepada validator ahli, validator media, validator praktisi (guru), dan subjek uji coba. Analisis data untuk data verbal yang didapatkan dari kegiatan wawancara dan komentar yang tertulis di dalam angket validasi dilakukan dengan cara mencatat poinpoin dari hasil kegiatan wawancara dan komentar yang terdapat dalam angket. Setelah itu, mengevaluasi poin-poin penting tersebut dijadikan sebagai acuan untuk merevisi produk.Selanjutnya, untuk data numeral digunakan analisis kuantitatif pada data yang diproleh dari tes cloze, angket validasi ahli, angket validasi praktisi, dan angket uji coba, serta uji efektivitas produk. Jadi, terdapat tiga model analisis untuk data numeral di dalam penelitian dan pengembangan ini, yaitu analisi untuk tes cloze, analisis kuantifikasi angket validasi dan uji coba, serta analisis efektivitas produk.

Instrumen pengumpulan data yang digunakan untuk mendapat data dalam penelitian dan pengembangan ini ada dua, yaitu instrumen utama dan instrumen pendukung, (1) instrumen utamanya adalah prototipe bahan ajar buku paket bahasa Indonesia K.13 Kemendikbud, (2) instrumen pendukung meliputi, angket dan pedoman wawancara. Pedoman wawancara digunakan untuk mewawancarai guru ketika tahap analisis kebutuhan. Angket terdiri dari 4 model yakni, a) angket untuk keperluan analisis kebutuhan, b) angket validasi ahli (isi dan media), 3) angket validasi praktisi, dan d) angket penilaian untuk uji coba produk (siswa). 


\title{
PENGEMBANGAN BAHAN AJAR BAHASA INDONESIA BERGAMBAR PADA MATERI “TEKS PERCAKAPAN" PADA SISWA KELAS V SD ST. YOSEPH MEDAN
}

\author{
Nurcahaya Simaremare
}

\section{Mahasiswa Magister Pendidikan Bahasa Indonesia Unimed}

\begin{abstract}
Abstrak
Pendidikan Bahasa Indonesia merupakan salah satu aspek penting yang perlu diajarkan kepada peserta didik di sekolah. Pendidikan Bahasa Indonesia sebagai salah satu mata pelajaran yang diberikan di sekolah diharapkan agar peserta didik mampu menguasai, memahami dan dapat mengimplementasikan keterampilan berbahasa. Selain itu belajar bahasa pada hakikatnya adalah belajar komunikasi. Oleh karena itu, pembelajaran bahasa diarahkan untuk meningkatkan kemampuan pembelajar dalam berkomunikasi, baik lisan maupun tulis.

Hasil pengembangan bahan ajar bahasa Indonesia bergambar pada materi teks percakapan diperoleh hasil validasi dengan kualitas yang sangat baik. Hal ini dapat dilihat dari validasi ahli materi 1 dengan persentase $85 \%$ dengan kategori sangat baik, validasi ahli materi 2 dengan hasil persentase 86,4\% dengan kategori sangat baik dan validasi oleh ahli bahan ajar dengan persentase $90 \%$ dengan kategori sangat baik. Maka dapat disimpulkan bahwa bahan ajar layak untuk dikembangkan dalam proses pembelajaran sebagai pendukung pencapaian keberhasilan pembelajaran dan ketercapaian tujuan pembelajaran. Hal utama yang mendukung keberhasilan kegiatan pembelajaran adalah strategi pembelajaran, metode atau model pembelajaran, dan media pembelajaran serta bahan ajar. Dalam hal ini pembelajaran Bahasa Indonesia difokuskan kepada penggunaan bahan ajar sebagai salah satu faktor pendukung guna membantu siswa dalam proses pembelajaran. Bahan ajar yang disampaikan guru hendaknya mengacu pada tujuan pembelajaran. Oleh karena itu, guru mempunyai keleluasaan untuk mengembangkan bahan ajar yang akan disampaikan sejauh tidak menyimpang dari tujuan pembelajaran.
\end{abstract}


Kata kunci : Bahasa Indonesia,bahan ajar, teks bergambar, teks percakapan.

\section{PENDAHULUAN}

Sebagai seorang pendidik, guru dituntut untuk kreatif dalam proses belajar mengajar. Salah satunya yaitu dengan mengembangkan bahan ajar untuk kegiatan pembelajaran. Namun dalam kenyataanya, masih banyak sekolah dalam proses pembelajaran belum mengembang kan bahan ajar, salah satunya yaitu di SD St. Yoseph Medan

Dalam bahan ajar bahasa Indonesia, unsur bahasa sangatlah penting untuk diperhatikan. Pembelajaran bahasa diarahkan untuk meningkatkan kemampuan siswa untuk berkomunikasi dalam bahasa Indonesia yang baik dan benar. Namun pelaksanaan pembelajaran bahasa Indonesia di kelas V ini masih kurang bervariasi. Sehingga tujuan pembelajaran Bahasa Indonesia yang akan dicapai, yaitu siswa terampil berbahasa Indonesia baik lisan maupun tulisan yang mencakup 4 aspek (mendengarkan, berbicara, membaca, dan menulis) belum tercapai seperti yang diharapkan. Seperti pada mata pelajaran Bahasa Indonesia pada materi ajar "Teks Percakapan". Dalam materi ini siswa belum mengusai pelajaran dengan baik. Saat pembelajaran berlangsung, siswa kurang mendengarkan dan memperhatikan penjelasan guru. Sehingga pada saat guru menjelaskan mengenai materi teks percakapan, siswa belum paham mengenai materi yang diajarkan. Hal ini berpengaruh ketika siswa diminta membaca teks percakapan. Siswa cenderung hanya biasa saja dalam membaca teks percakapan tanpa memperhatikan lafal dan intonasi yang benar. Dalam penguasaan penggunaan tanda baca juga kurang tepat. Sehingga siswa belum dapat menulis sebuah teks percakapan yang sesuai dengan kaidah penulisan.

\section{TUJUAN}

Penelitian ini bertujuan untuk :

Menumbuhkan minat siswa untuk belajar Bahasa Indonesia dengan bahan ajar yang lebih menarik dari bahan ajar yang sebelumnya. Sehingga dengan adanya bahan ajar yang sudah dikembangkan ini, proses pembelajaran menjadi lebih menyenangkan 


\section{Landasan Teori}

Menurut Borg and Gall (Zainal Arifin, 2012: 127) penelitian pengembangan adalah suatu proses yang dipakai untuk mengembangkan dan memvalidasi produk pendidikan. Bahan ajar adalah segala bentuk bahan yang disusun secara sistematis yang memungkinkan siswa dapat belajar dengan dirancang sesuai kurikulum yang berlaku. Dengan adanya bahan ajar, seorang guru akan lebih runtut dalam mengajarkan materi kepada siswa dan tercapai semua kompetensi yang telah ditentukan sebelumnya (Ika Lestari, 2013: 1). Menurut Ika Lestari, (2013: 5-6) bahan ajar memiliki beragam jenis, ada yang cetak maupun noncetak. Bahan ajar cetak yang sering dijumpai antara lain berupa handout, buku, modul, brosur, dan lembar kerja siswa. Sedangkan bahan ajar noncetak meliputi bahan ajar dengar (audio) seperti kaset, radio, piringan hitam, dan compack disc audio. Bahan ajar pandang dengar (audio visual) seperti video compack disc dan film. Bahan ajar multimedia interaktif (interactive teaching material) seperti CAI (Computer Assisted Instruction), compact disk (CD) multimedia pembelajaran interaktif, dan bahan ajar berbasis web (web based learning materials). Menurut Slamet, (2007: 6) pengajaran bahasa Indonesia pada hakikatnya adalah pengajaran keterampilan berbahasa, bukan pengajaran tentang bahasa. Tata bahasa, kosakata, dan sastra disajikan dalam konteks yaitu dalam kaitanya dengan keterampilan tertentu yang tengah diajarkan, bukan sebagai pengetahuan tata bahasa, teori pengembanagan kosakata, teori sastra sebagai pendukung atau alat penjelas. Keterampilan-keterampilan berbahasa yang perlu ditekankan pengajaran berbahasa Indonesia adalah keterampilan reseptif (keterampilan mendengarakan dan membaca) dan keterampilan produktif (keterampilan menulis dan keterampilan berbicara). Cecep dan Bambang, (2011: 45) mengemukakan bahwa gambar atau foto adalah media pembelajaran yang sering digunakan. Media ini merupakan bahasa yang umum, dapat dimengerti, dan dinikmati oleh semua orang dimana-mana. Gambar atau foto berfungsi untuk menyampaikan pesan melalui gambar yang menyangkut indera pengelihatan. Adapun pengertian gambar atau foto menurut Hujair, (2013: 81) adalah media yang paling umum digunakan orang, karena media ini mudah dimengerti dan dapat dinikmati, mudah didapatkan dan dijumpai dimana, serta banyak memberikan penjelasan bila dibandingkan dengan verbal. Menurut Edi Warsidi, (2008:10) percakapan hampir sama dengan wawancara. Baik dalam wawancara maupun 
percakapan, ada pihak yang bertanya dan pihak yang menjawab. Perbedaannya, dalam percakapan, penanya dan penjawab dapat berbicara bergantian, sedangkan dalam wawancara tidak demikian. Sedangkan menurut Sri Murni dan Ambar, (2008: 36) "percakapan bisa dilakukan oleh dua orang atau lebih. Menurut Djamarah, (2012: 19-24) prestasi belajar adalah penilaian pendidikan tentang kemajuan siswa dalam segala hal yang dipelajari di sekolah yang menyangkut pengetahuan atau kecakapan atau keterampilan yang dinyatakan sesudah hasil penilaian. Sedangkan menurut Fathurrohman dan Sulistyorini, (2012: 117) prestasi belajar adalah hasil yang ditunjukan siswa setelah melakukan proses belajar mengajar.

\section{Metode Penelitian}

Dalam penelitian ini akan dilakukan pengumpulan data dengan cara meneliti kemampuan berbahasa terhadap berpikir kritis . Adapun data nara sumber adalah sebagai berikut.

Kelas $\quad$ : V SD

Sekolah $\quad$ : SD St. Yoseph Medan, Jl. Pemuda No 3a Medan

\section{HASIL PENELITIAN DAN PEMBAHASAN}

\section{Kualitas bahan ajar}

Kualitas bahan ajar dapat ditunjukkan pada hasil validasi oleh ahli materi dan ahli bahan ajar. Adapun hasil persentase penilaian kualitas bahan ajar, Hal ini dapat dilihat dari validasi ahli materi 1 dengan persentase $85 \%$ dengan kategori sangat baik, validasi ahli materi 2 dengan hasil persentase $86,4 \%$ dengan kategori sangat baik dan validasi oleh ahli bahan ajar dengan persentase $90 \%$ dengan kategori sangat baik. Maka dapat disimpulkan bahwa bahan ajar layak untuk dikembangkan dalam proses pembelajaran sebagai pendukung pencapaian keberhasilan pembelajaran dan ketercapaian tujuan pembelajaran. Adapun hasil produk pengembangan bahan ajar ini adalah sebagai berikut.

Gambar 1. Gambar Pengembangan Bahan Ajar 


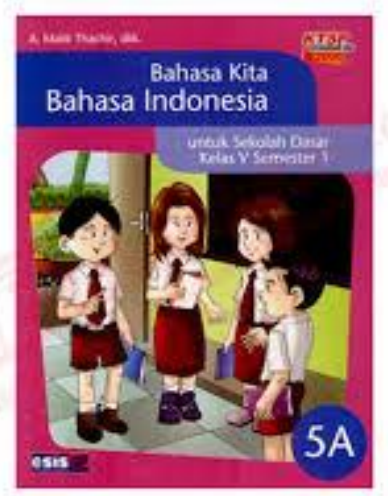

2. Daya Tarik Bahan Ajar berdasarkan Angket Respon Siswa

Adapun hasil persentase penilaian daya tarik bahan ajar berdasarkan respon siswa dapat ditunjukan bahwa Daya tarik bahan ajar diperoleh dari uji coba kelompok kecil, dimana siswa tertarik dengan pembelajaran menggunakan bahan ajar bergambar pada materi teks percakapan. Hal ini dapat dibuktikan dari hasil perolehan data dari pengisian angket diperoleh jumlah skor 326 dengan persentase 86,9\% sehingga masuk dalam kategori sangat menarik. Dengan adanya bahan ajar yang menarik dan tampilan gambar yang bervariasi, pembelajaran yang berlangsung menjadi lebih kondusif serta siswa aktif dan ekspresif. Siswa lebih aktif mengemukakan pendapat dan merespon guru.

Selain uji coba kelompok kecil dilakukan juga ujicoba kelompok besar. Keberhasilan ujicoba kelompok kecil, diberlakukan juga pada pembelajaran ujicoba kelompok besar untuk meningkatkan prestasi belajar siswa menggunakan bahan ajar berupa media gambar pada materi teks percakapan. Siswa lebih mandiri dalam menyelesaikan masalah atau pencarian jawaban atas tugas dari guru dengan tema yang sudah ditentukan. Siswa tertarik dengan bahan ajar karena bahan ajar yang disajikan menarik dengan tampilan gambar yang warna-warni dan bahasa yang mudah dipahami. Hal ini dapat dibuktikan dari hasil perolehan data dari pengisian angket diperoleh jumlah skor 2078 dengan persentase 92,3\% sehingga masuk dalam kategori sangat menarik.

3. Prestasi Belajar Siswa

Prestasi belajar adalah penilaian pendidikan tentang kemajuan siswa dalam segala hal yang dipelajari di sekolah yang menyangkut pengetahuan, kecakapan atau 
keterampilan yang dinyatakan sesudah hasil penilaian. Penilaian tidak hanya ditunjukan pada hasil tes berupa angka, tetapi juga pada penilaian sikap. Penilaian sikap yang dimaksud adalah bagaimana sikap atau perubahan ke arah yang lebih baik. penilaian sikap dalam penelitian ini menggunakan analisis observasi sikap siswa pada ujicoba kelompok kecil dan ujicoba kelompok besar. Analisis observasi sikap siswa pada saat ujicoba kelompok kecil menunjukan hasil perolehan persentase $88 \%$, sedangkan pada saat ujicoba kelompok besar memperoleh hasil persentase $89 \%$. Hal ini menunjukan bahwa sikap siswa selama pembelajaran pada saat menggunakan bahan ajar dengan media gambar lebih baik dalam menerima materi pelajaran. Siswa cenderung memperhatikan apa yang disampaikan guru menggunakan bahan ajar dengan media gambar sehingga siswa mudah memahami materi. Hasil positif ditunjukkan pada ujicoba kelompok kecil, dan kelompok besar sehingga bahan ajar dengan media gambar pada materi teks percakapan mata pelajaran Bahasa Indonesia dapat dikembangkan dan dipergunakan dalam pembelajaran. Hal ini terbukti pada saat siswa diberikan tugas secara berkelompok untuk membuat teks percakapan berdasarkan tema dan gambar yang telah ditentukan. Kemudian siswa membacakan hasil kerja kelompok yang berupa teks percakapan di depan kelas. Setelah diamati oleh guru dengan menggunakan lembar penilaian sikap siswa, rata-rata siswa mampu menulis teks percakapan sesuai dengan tanda baca yang tepat. Selain itu siswa juga mampu membaca dengan lafal dan intonasi yang tepat. Siswa juga memperhatikan ketika temanya sedang mempresentasikan hasil kerja kelompok lain. Penggunaan bahan ajar dengan media gambar sudah menunjukan hasil yang baik dengan tercapainya tujuan pembelajaran yang mencakup penilaian 4 aspek yaitu mendengarkan, berbicara, membaca dan menulis. Indikator pencapaian prestasi belajar berupa angka ditunjukan dengan alat ukur pencapaian dan peningkatan ratarata prestasi belajar siswa pada kegiatan pembelajaran. Alat ukur yang digunakan adalah soal pretes dan postes setelah menggunakan bahan ajar dengan media gambar. Kegiatan pembelajaran ini menunjukkan adanya peningkatan bahwa media pembelajaran akan mempengaruhi nilai yang diperoleh siswa yaitu menjadi maksimal. Karena pembelajaran terkesan lebih menarik dan tidak konvensional, siswa ikut terlibat aktif dalam kegiatan pembelajaran sehingga siswa lebih memahami 
apa yang disampaikan guru. Peningkatan dilihat dari perolehan nilai pretes maupun postes terjadi perbedaan rata-rata skor, hal ini menunjukkan adanya peningkatan ratarata perolehan nilai yaitu dari 6,1 menjadi 8,2. Nilai tersebut sudah diatas KKM yang telah ditentukan sekolah yaitu 75. Sehingga dapat disimpulkan bahwa ada peningkatan rata-rata prestasi belajar siswa setelah menggunakan bahan ajar dengan media gambar pada materi teks percakapan.

\section{SIMPULAN}

Berdasarkan hasil penelitian pengembangan ini dapat disimpulkan sebagai berikut.

1. Hasil pengembangan bahan ajar bahasa Indonesia bergambar pada materi teks percakapan diperoleh hasil validasi dengan kualitas yang sangat baik. Hal ini dapat dilihat dari validasi ahli materi 1 dengan persentase 85\% dengan kategori sangat baik, validasi ahli materi 2 dengan hasil persentase $86,4 \%$ dengan kategori sangat baik dan validasi oleh ahli bahan ajar dengan persentase $90 \%$ dengan kategori sangat baik. Maka dapat disimpulkan bahwa bahan ajar layak untuk dikembangkan dalam proses pembelajaran sebagai pendukung pencapaian keberhasilan pembelajaran dan ketercapaian tujuan pembelajaran.

2. Respon siswa terhadap bahan ajar bahasa Indonesia bergambar pada materi teks percakapan yang telah dikembangkan pada ujicoba kelompok kecil diperoleh hasil dengan jumlah skor 326 dengan persentase 86,9\% sehingga masuk dalam kategori sangat menarik, begitu juga dengan respon siswa pada uji coba kelompok besar dengan jumlah skor 2078 dengan persentase $92,3 \%$ sehingga masuk dalam kategori sangat menarik. Maka dapat disimpulkan bahwa siswa tertarik dengan bahan ajar media gambar yang digunakan dalam pembelajaran, karena bahan ajar yang dikembangkan sangat menarik.

3. Hasil perolehan nilai rata-rata pretes dari keseluruhan siswa yaitu 6,1, sedangkan perolehan nilai rata-rata postes dari keseluruhan siswa yaitu 8,2. Berdasarkan hasil perolehan nilai ratarata pretes dan postes menunjukan adanya peningkatan rata-rata nilai siswa sebelum dan setelah diberikan produk bahan ajar dengan media gambar.

Dengan demikian dapat disimpulkan bahwa ada peningkatan nilai rata-rata prestasi belajar siswa setelah menggunakan bahan ajar bahasa Indonesia bergambar pada materi teks 
percakapan. Hal ini juga dapat dilihat dari penilaian sikap siswa selama pembelajaran. Analisis observasi sikap siswa pada saat ujicoba kelompok kecil menunjukan hasil perolehan persentase $88 \%$, sedangkan pada saat ujicoba kelompok besar memperoleh hasil persentase 89\%. Hal ini menunjukan bahwa sikap siswa selama pembelajaran pada saat menggunakan bahan ajar dengan media gambar lebih baik dalam menerima materi pelajaran. Sehingga tujuan pembelajaran yaitu siswa terampil berbahasa Indonesia baik lisan maupun tulisan yang mencakup 4 aspek (mendengarkan, berbicara, membaca, dan menulis) dapat tercapai seperti yang diharapkan.

\section{DAFTAR PUSTAKA}

Andi Prastowo. 2013. Panduan Kreatif Membuat Bahan Ajar Inovatif. Jakarta: Diva Press.

Andi Prastowo. 2014. Pengembangan Bahan Ajar Tematik. Jakarta: Kencana Prenada media Group.

Baharudin dan Esa Nur Wahyuni. 2007. Teori Belajar dan Pembelajaran. Yogyakarta: AR-Ruzz Media.

Cecep Kustandi dan Bambang Sutjipto. 2011. Media Pembelajaran. Bogor: Ghalia Indonesia.

Daen Nurjamal, dkk. 2011. Terampil Berbahasa. Bandung: Alfabeta CV. Daryanto dan Aris Dwicahyono. 2014. Pengembangan Perangkat Pembelajaran. (Silabus, RPP, PHB, Bahan Ajar. Yogyakarta: Gava Media. Edi Warsidi dan Farika. 2008. Bahasa Indonesia membuatku cerdas 5: untuk kelas V Sekolah Dasar dan Madrasah Ibtidaiyah. Jakarta: Pusat Perbukuan, Departemen Pendidikan Nasional.

Eko Putro Widoyoko. 2014. Teknik Penyusunan Instrumen Penelitian. Yogyakarta: Pustaka Pelajar. Gede Nurjaya. 2012. "Pengembangan bahan ajar metode pembelajaran bahasa dan sastra Indonesia berbasis pembelajaran kooperatif Jigsaw untuk meningkatkan pemahaman dan kemampuan aplikatif mahasiswa". Jurnal Pendidikan Bahasa: 102-109. 
Hujair AH Sanaky. 2013. Media Pembelajaran Interaktif-Inovatif. Yogyakarat: Kaukaba Dipantara. Ika Lestari. 2013. Pengembangan Bahan Ajar Berbasis Kompetensi (Sesusai dengan kurikulum tingkat satuan pendidikan). Padang: Akademia Permata.

Meina Febriani. 2012. "Pengembangan bahan ajar apresiasi dongeng Banyumas bagi siswa SD kelas rendah". Jurnal Pendidikan Sastra dan Bahasa 1(1). Universitas Negeri Semarang: 1-7.

Muhammad Fathurrohman dan Sulistyorini. 2012. Belajar dan Pembelajaran (Membantu meningkatkan mutu pembelajaran sesuai standar nasional). Yogyakarta: Teras. 


\title{
PERILAKU MEMBACA SISWA KELAS VIII-B SMP NASRANI 1 MEDAN
}

\author{
Oleh \\ Putri Dewita Napitupulu \\ Pendidikan Bahasa dan Sastra Indonesia \\ Pascasarjana Universitas Negeri Medan \\ putrinapitupulu09@gmail.com
}

\begin{abstract}
Abstrak
Gerakan literasi adalah adalah sebuah upaya yang dilakukan secara menyeluruh dan berkelanjutan untuk menjadikan sekolah sebagai organisasi pembelajaran yang warganya literat sepanjang hayat melalui pelibatan publik mulai dari semua pemangku kepentingan di bidang pendidikan, dari tingkat pusat, provinsi, kabupaten/kota, hingga satuan pendidikan (peserta didik, guru, kepala sekolah, tenaga kependidikan, pengawas sekolah) juga melibatkan Komite Sekolah, orang tua/wali murid peserta didik), akademisi, penerbit, media massa, masyarakat (tokoh masyarakat yang dapat merepresentasikan keteladanan, dunia usaha, dll). Riset ini bertujuan untuk mengetahui kemampuan literasi siswa di SMP Nasrani 1 Medan dan mengetahui strategi yang tepat untuk meningkatkan kemampuan literasi siswa. Pengumpulan data secara eksklusif dilakukan pada siswa kelas VIII-B SMP Nasrani 1 Medan dengan jumlah siswa 5 orang. Riset ini dilakukan pada bulan September 2018. Perilaku kegiatan membaca siswa kelas VIII-B SMP Nasrani 1 Medan masih tergolong rendah, terlihat dari respon siswa membaca serius, memnfaatkan waktu, membaca dan mencatat, serta menanya.

Kata kunci: Literasi, Buku, Siswa, Sekolah.
\end{abstract}

\section{A. PENDAhuluan}

Perkembangan zaman yang semakin pesat menuntut setiap orang memiliki kegemaran membaca dan menulis, hal ini diperlukan guna memperoleh pengetahuan dan wawasan yang luas untuk meningkatkan kecerdasannya. Kemampuan membaca mempunyai peran dan menjadi salah satu kunci dalam kesuksesan dikehidupan seseorang, karena setiap informasi dan pengetahuan apapun yang diperoleh tidak terlepas dari kegiatan membaca. Tidak berbeda dengan membaca, menulis pun memiliki peran tersendiri bagi kehidupan seseorang. Menurut Cakiroglu (2012:5588) writing skill is more than a kinesthetic activity which is a more complex and higher level of cognitive activity that should be considered together with the reading skill. Di sekolah dasar kemampuan membaca dan menulis menjadi hal yang memegang peranan penting, dikarenakan ketika seseorang mampu untuk menulis maka secara tidak langsung seseorang tersebut juga mampu untuk membaca dan tanpa hal tersebut siswa akan mengalami kesulitan belajar pada saat itu dan pada masa yang akan datang. 
Pada tahun 2013 Kementerian Pendidikan dan Kebudayaan melalui Peraturan Menteri nomor 23 tahun 2013 mencanangkan sebuah gerakan literasi sekolah untuk membantu siswa dalam menumbuhkan budaya membaca dan menulis dilingkungan sekolah. Alwasilah (2012:177) mengemukakan bahwa mengajarkan literasi pada intinya menjadikan manusia yang secara fungsional mampu berbaca-tulis, terdidik, cerdas, dan menunjukkan apresiasi terhadap sastra. Dikarenakan selama ini pendidikan di Indonesia mampu mencetak lulusan yang terdidik namun kurang memiliki apresiasi terhadap sastra.

Gerakan literasi sekolah (GLS) adalah kemampuan mengakses, memahami, dan menggunakan sesuatu secara cerdas melalui berbagai aktivitas, antara lain membaca, melihat, menyimak, menulis dan/ atau berbicara (Faizah, 2016:2). Kompetensi literasi pada kelas tinggi menekankan siswa untuk mampu melakukan analisis secara kritis, seperti melakukan wawancara, pengamatan lingkungan, menulis laporan, dan melakukan observasi ( Widodo dkk 2015:60).

Pendidikan berbahasa sejak dini mampu membiasakan siswa untuk berekspresi sesuai kemampuannya, baik secara lisan maupun secara tulis. Menurut Wildova (2014:334) its main principle is literacy approach to initial reading and writing. Ketika seseorang memiliki kemampuan berbahasa yakni membaca dan menulis, maka bisa dikatakan ia memiliki kemampuan literasi. Kegiatan literasi berkonsentrasi pada kemampuan untuk menerima berbagai bahasa yang terdapat dalam setiap buku dan diharapkan hal ini akan meningkatkan minat membaca dan menulis siswa. Adanya rasa senang, rasa puas dalam diri, partisipasi aktif yang tanpa dipaksa, dan lebih menyukai kegiatan tersebut tanpa membandingkan dengan kegiatan lain merupakan tanda adanya kemunculan minat dalam diri seseorang.

Dalam kegiatan pembiasaan ini peran dari beberapa pihak seperti guru, orang tua, perpustakaan, dan pemerintah sangat diperlukan yang berfungsi sebagai media siswa untuk lebih mengetahui dan memahami kegiatan pembiasaan tersebut. Berdasarkan pernyataan di atas maka peneliti tertarik untuk mengkaji lebih dalam mengenai kegiatan pembiasaan membaca tersebut dengan mengambil judul "Perilaku membaca siswa kelas VIII-B SMP Nasrani 1 Medan”.

Berdasarkan latar belakang di atas, peneliti merumuskan masalah dalam penelitian ini yaitu, bagaimana perilaku membaca siswa kelas VIII-B SMP Nasrani 1 Medan? 


\section{B. KAJIAN PUSTAKA \\ 1. Hakikat Gerakan Literasi}

(Alwasilah, 2001) literasi diartikan sebagi melek huruf, kemampuan baca-tulis, kemelekwacanaan atau kecakapan dalam membaca dan menulis. Sedangkan (White, 1985:46) menyatakan bahwa literasi merupakan kompetensi dalam memahami wacana, baik sebagai pembaca maupun sebagai penulis sehingga sehingga menampakkan pribadi sebagai profesional berpendidikan yang tidak hanya menerapkan untuk selama kegiatan belajar melainkan menerapkannya secara baik untuk selamanya.

Gerakan literasi adalah adalah sebuah upaya yang dilakukan secara menyeluruh dan berkelanjutan untuk menjadikan sekolah sebagai organisasi pembelajaran yang warganya literat sepanjang hayat melalui pelibatan publik mulai dari semua pemangku kepentingan di bidang pendidikan, dari tingkat pusat, provinsi, kabupaten/kota, hingga satuan pendidikan (peserta didik, guru, kepala sekolah, tenaga kependidikan, pengawas sekolah) juga melibatkan Komite Sekolah, orang tua/wali murid peserta didik), akademisi, penerbit, media massa, masyarakat (tokoh masyarakat yang dapat merepresentasikan keteladanan, dunia usaha, dll).

Gerakan Literasi Sekolah (GLS) memperkuat gerakan penumbuhan budi pekerti sebagaimana dituangkan dalam Peraturan Menteri Pendidikan dan Kebudayaan Nomor 23 Tahun 2015. Salah satu kegiatan di dalam gerakan tersebut adalah kegiatan 15 menit membaca buku nonpelajaran sebelum waktu belajar dimulai. Kegiatan ini dilaksanakan untuk menumbuhkan minat baca peserta didik serta meningkatkan keterampilan membaca agar pengetahuan dapat dikuasai secara lebih baik. Materi baca berisi nilai-nilai budi pekerti, berupa kearifan lokal, nasional, dan global yang disampaikan sesuai tahap perkembangan peserta didik.

\section{Tujuan Gerakan Literasi Sekolah}

Tujuan Umum Gerakan Literasi Sekolah (GLS) adalah Menumbuhkembangkan budi pekerti peserta didik melalui pembudayaan ekosistem literasi sekolah yang diwujudkan dalam Gerakan Literasi Sekolah agar mereka menjadi pembelajar sepanjang hayat.

Tujuan Khusus Gerakan Literasi Sekolah (GLS) adalah: (a) Menumbuhkembangkan budaya literasi di sekolah. (b) Meningkatkan kapasitas warga dan lingkungan sekolah agar literat. (c) 
Menjadikan sekolah sebagai taman belajar yang menyenangkan dan ramah anak agar warga sekolah mampu mengelola pengetahuan. (d) Menjaga keberlanjutan pembelajaran dengan menghadirkan beragam buku bacaan dan mewadahi berbagai strategi membaca.

\section{Tahapan Pelaksanaan Gerakan Literasi Sekolah}

Ada tiga tahapan dalam melaksanakan gerakan literasi di sekolah, yaitu:

a. Pembiasaan

Penumbuhan minat baca melalui kegiatan 15 menit membaca (Permendikbud No 23 Tahun 2015).

b. Pengembangan

Meningkatkan kemampuan literasi melalui kegiatan menanggapi buku pengayaan.

c. Pembelajaran

Meningkatkan kemampuan literasi di semua mata pelajaran: menggunakan buku pengayaan dan strategi membaca di semua mata pelajaran.

\section{METODOLOGI PENELITIAN}

Dalam riset mini ini akan dilakukan pengumpulan data dengan cara meneliti kegiatan literasi siswa SMP. Penelitian ini dilakukan di SMP Nasrani 1 Medan pada tanggal 25-27 September 2018. Populasi dalam penelitian ini adalah seluruh siswa SMP Nasrani 1 Medan. Sampel yang diambil dalam penelitian ini adalah siswa kelas VIII-B SMP Nasrani 1 Medan yang berjumlah 35 orang.

Metode yang digunakan dalam penelitian ini adalah metode kualitatif deskriptif. Menurut Sudaryanto (1992:62), penelitian deskriptif digunakan untuk menggambarkan suatu keadaan berdasarkan fakta yang ada atau fenomena yang memang secara empiris hidup pada penuturpenuturnya sehingga yang dihasilkan atau dicatat berupa tafsiran bahasa yang bisa dikatakan sifatnya seperti potret yaitu paparan seperti apa adanya. Pada penelitian ini, peneliti menggunakan teknik pengumpulan data dengan observasi pada siswa kelas VIII-B SMP Nasrani 1 Medan. 
D. HASIL DAN PEMBAHASAN

1. Hasil Penelitian

Grafik Perilaku Membaca Siswa Kelas VIII-B SMP Nasrani 2 Medan



\section{Pembahasan}

Data grafik perilaku membaca siswa kelas VIII-B SMP Nasrani 1 Medan menunjukkan kegiatan Gerakan Literasi Sekolah sebagai berikut.

- Hari ke-1: Siswa yang membawa buku berjumlah 15 orang. Kemudian siswa yang membuka buku sebanyak 30 orang. Melihat judul berjumlah 35 orang. Siswa yang memegang buku sebanyak 35 orang. Membaca serius hanya 3 orang dan yang membaca asik berjumlah 5 
orang. Siswa yang memanfaatkan waktu sebanyak 3 orang. Kekurangan waktu GLS 2 orang. Siswa yang membaca dan mencatat hanya 2 orang, menanya 2 orang.

- Hari ke-2: Siswa yang membawa buku berjumlah 21 orang. Kemudian siswa yang membuka buku sebanyak 32 orang. Melihat judul berjumlah 32 orang. Siswa yang memegang buku sebanyak 35 orang. Membaca serius hanya 5 orang dan yang membaca asik berjumlah 6 orang. Siswa yang memanfaatkan waktu sebanyak 6 orang. Kekurangan waktu GLS 3 orang. Siswa yang membaca dan mencatat hanya 3 orang, menanya 4 orang.

- Hari ke-3 : Siswa yang membawa buku berjumlah 28 orang. Kemudian siswa yang membuka buku sebanyak 35 orang. Melihat judul berjumlah 35 orang. Siswa yang memegang buku sebanyak 35 orang. Membaca serius hanya 7 orang dan yang membaca asik berjumlah 8 orang. Siswa yang memanfaatkan waktu sebanyak 6 orang. Kekurangan waktu GLS 6 orang. Siswa yang membaca dan mencatat hanya 4 orang, menanya 3 orang.

Dari uraian di atas dapat diketahui perilaku kegiatan membaca siswa kelas VIII-B SMP Nasrani 1 Medan masih tergolong rendah, terlihat dari respon siswa membaca serius, memnfaatkan waktu, membaca dan mencatat, serta menanya.

Hambatan pihak sekolah dalam meningkatkan minat membaca dan menulis siswa kelas atas melalui kegiatan literasi di SMP Nasrani 1 Medan ini hanyalah hambatan yang masih bisa diperbaiki yang berupa pembiasaan siswa untuk menggemari membaca dan menulis. Selain itu juga, karena guru masih belum menerapkan metode yang sesuai untuk mendorong anak menggemari kegiatan membaca dan menulis.

Upaya yang diterapkan oleh pihak sekolah dalam menghadapi hambatan peran kegiatan literasi dalam meningkatkan minat membaca dan menulis siswa yakni dengan memberi sosialisasi ketika upacara supaya anak sering mengunjungi perpustakaan untuk membaca dan menulis dan secara berkala mendiskusikan upaya atau metode yang tepat untuk diterapkan dalam pelaksanaan kegiatan literasi agar minat membaca dan menulis siswa meningkat.

Selain itu, upaya yang diterapkan di dalam menghadapi hambatan dalam implementasi kegiatan literasi untuk meningkatkan minat membaca dan menulis siswa adalah dengan membuat jadwal masuk perpustakaan per kelas.

\section{E. PENUTUP}

\section{Simpulan}


Berdasarkan hasil penelitian dan pembahasan yang telah dipaparkan pada bab sebelumnya, maka penelitian ini dapat disimpulkan sebagai berikut : Kegiatan literasi di SMP Nasrani 1 Medan memiliki peran dalam meningkatkan minat membaca dan menulis siswa, terlihat dari antusias siswa yang mulai mampu menerapkan kegiatan membaca dan menulis didalam kelas maupun dirumah. Dari kegiatan ini pula siswa mendapatkan manfaat dan secara tidak langsung motivasi siswa untuk menyukai kegiatan membaca dan menulis semakin meningkat.

Hambatan yang dialami pihak sekolah dalam meningkatkan minat membaca dan menulis siswa kelas atas melalui kegiatan literasi yakni kedisiplinan, pembiasaan siswa, minat, dan metode yang diterapkan guru.

\section{Saran}

Upaya pihak sekolah dalam menghadapi hambatan kegiatan literasi siswa yakni dengan memberi sosialisasi ketika upacara supaya anak sering mengunjungi perpustakaan untuk membaca dan menulis dan secara berkala mendiskusikan upaya atau metode yang tepat untuk diterapkan dalam pelaksanaan kegiatan literasi agar minat membaca dan menulis siswa meningkat. Selain itu, upaya yang diterapkan di dalam menghadapi hambatan dalam implementasi kegiatan literasi untuk meningkatkan minat membaca dan menulis siswa adalah dengan membuat jadwal masuk perpustakaan per kelas serta mengadakan lomba-lomba sebagai wadah siswa untuk berpartisipasi aktif. 


\section{DAFTAR PUSTAKA}

Alwasilah, A. Chaedar. 2001. Membangun Kota Berbudaya Literasi. Jakarta: Media Indonesia 2012. Rekayasa Literasi. Bandung: PT Kiblat Buku Utama

Arikunto, Suharsimi. 2006. Prosedur Penelitian Suatu Pendekatan Praktik. Yogyakarta : Rineka Cipta

Cakiroglu, Ahmet and Hayriye Gul Kuruyer. 2012. First grade elementary school student's family involvement in theprocess of reading and writing skills acquisition. Procedia Social and Behavioral Sciences 46: 5588 - 5592.

Direktorat Jendral Pendidikan Dasar Dan Menengah Kementrian Pendidikan Dan Kebudayaan. Jakarta

White, James Boyd. 1985. The Invisible Discourse of Law: Reflections on Legal Literacy and General Education Essay dalam Praticia L. Stock Essay on Theory and Practise in the Teaching of Writing. USA: Boynton Cook Publisher Inc.

Wildova, Radka. 2014. Initial Reading Literacy Development in Current Primary School Practice. Procedia - Social and Behavioral Sciences 159: 334-339. (http://www.sciencedirect.com/science) 


\title{
PEMBELAJARAN PARIKAN (PANTUN JAWA) DALAM KEARIFAN LOKAL BUDAYA JAWA SEBAGAI PEMBENTUK KAREAKTER SISWA
}

\author{
Oleh: Tri Indah Prasasti \\ (Pascasarjana Universitas Negeri Medan) \\ Indah_dheniez@yahoo.co.id
}

\begin{abstract}
Abstrak
Definisi parikan ialah tradisi lisan, budaya lisan dan adat lisan adalah pesan atau kesaksian yang disampaikan secara turun-temurun dari satu generasi ke generasi berikutnya. Pesan atau kesaksian itu disampaikan melalui ucapan, pidato, nyanyian, dan dapat berbentuk pantun, cerita rakyat, nasehat, balada, atau lagu. Dari segi makna dan fungsi parikan ada beragam parikan dalam masyarakat jawa yaitu sebagai ekspresi jiwa susah, sebagai control sosial, sebagai sindiran, sabagai ekspresi ilmu sejati, sebagai estetika gending dan lainnya. Parikan banyak digunakan sebagai pementasan atau sebagai hiburan berbeda dengan pantun yang digunakan sebagai pesan sosial dan untuk kebutuhan politik pada saat kampanye. Misalnya parikan digunakan untuk gara-gara wayang kulit, dagelan kethoprak, kentrung, dan jathilan. Pada tembang Jawa terdapat nilai-nilai moral sebagai pembentuk karakter siswa yang dapat diterapkan dalam kehidupan sehari-hari, terutama dalam membentuk siswa yang berkarakter. Hal itu pun berkaitan dengan konsep kearifan lokal yang kini mulai sering kita dengar.
\end{abstract}

\section{PENDAHULUAN}

Masuknya teknologi dari negara maju ke negara berkembang ikut masuk kebudayaan ke negara maju tersebut yang sangat memengaruhi perilaku negara-negara berkembang. Dengan demikian bangsa Indonesia yang termasuk masyarakat Suku Jawa mengalami pergeseran budaya. Kebergeseran budaya dengan teknologi membuat hilangnya keaslian budaya pada masyarakat. Budaya tersebut di dalamnya termasuk dalam budaya parikan yang sejak zaman dahulu menjadi salah satu budaya yang sama-sama dirasakan.

Parikan adalah bunyi yang terdiri atas dua ukara (bagian) yaitu untuk narik kawigaten, maksudnya adalah menarik perhatian dan yang kedua adalah minangka isi (yaitu sebagai isi). Parikan merupakan karya manusia yang seperti pantun tapi hanya terdiri dari dua larik. Parikan menggunakan purwakanthi swara yaitu dasar untuk menunjukkan perhitungan dalam wanda atau 
suku kata. Parikan adalah bagian dari tradisi lisan, budaya lisan dan adat lisan yang didefinisikan sebagai adalah pesan atau kesaksian yang disampaikan secara turun-temurun dari satu generasi ke generasi berikutnya. Pesan atau kesaksian itu disampaikan melalui ucapan, pidato, nyanyian, dan dapat berbentuk pantun, cerita rakyat, nasehat, balada, atau lagu.

Parikan ini mengandung banyak pesan moral yang dapat dijadikan pembelajaran siswa sebagai pemebentukan karekater siswa, karena di dalam parikan banyak pesan-pesan yang menyampaikan tentang toleransi, rendah diri, pemikiran yang kritis, religius, dan lain sebagainya.

\section{PEMBAHASAN}

\section{Parikan (Pantun Jawa)}

Pantun merupakan satu di antara sekian banyak genre kesusastraan yang lahir dan berkembang di nusantara. Pada mulanya, istilah pantun ini berasal dari bahasa Minangkabau "patuntun" yang berarti penuntun. Namun ternyata, istilah pantun ini pun dikenal juga di kalangan masyarakat Suku Jawa, Sunda, Batak, dan Melayu. Dalam masyarakat Suku Jawa, pantun dikenal dengan istilah "parikan." Dalam masyarakat Sunda dikenal dengan sebutan "paparikan". Sementara masyarakat Batak mengenal pantun dengan istilah "umpasa" (dibaca uppasa). Masih tentang pantun, dalam bahasa Melayu, pantun dikenal dengan istilah "quatrain".

Definisi parikan ialah tradisi lisan, budaya lisan dan adat lisan adalah pesan atau kesaksian yang disampaikan secara turun-temurun dari satu generasi ke generasi berikutnya. Pesan atau kesaksian itu disampaikan melalui ucapan, pidato, nyanyian, dan dapat berbentuk pantun, cerita rakyat, nasehat, balada, atau lagu. Pada cara ini, maka mungkinlah suatu masyarakat dapat menyampaikan sejarah lisan, sastra lisan, hukum lisan dan pengetahuan lainnya ke generasi penerusnya tanpa melibatkan bahasa tulisan. Istilah parikan memang asli Jawa. Parikan identik dengan pantun dalam bahasa Indonesia. Karena genre ini memuat banyak pari, kemudian disebut dengan parikan (artinya; memuat banyak pari). Di dalamnya terkandung sampiran dan isi (Endraswara, 2005:59). Parikan tersebut merepresentasikan pendidikan karakter

di dalamnya. Pendidikan karakter yang muncul dalam parikan adalah salah satu alternatif pembentukan pendidikan karakter pada anak-anak di sekolah. 
Parikan adalah bunyi yang pada bagian pertama sebagai sampiran atau penentu suara, kedua adalah berupa isi. Diungkap dalam bahasa Jawa, Parikan yaiku 'unen-unen rong perangan perangan (bagian) kapisan kanggo pancandan (sampiran) (kanggo pentokaning swara), dene perangan kapindho mawa teges (merupakan isi) kang dikarepake.' Parikan adalah bunyi yang terdiri atas dua bentuk yang pertama untuk menarik perhatian yang berupa sampiran dan yang kedua berupa isi.

Peran pantun (parikan) sebagai alat pemelihara bahasa, pantun berperan sebagai penjaga fungsi kata dan kemampuan menjaga alur berfikir. Pantun melatih seseorang berfikir tentang makna kata sebelum berujar. Ia juga melatih orang berfikir asosiatif, bahwa suatu kata bisa memiliki kaitan dengan kata yang lain. Secara sosial pantun memiliki fungsi pergaulan yang kuat, bahkan hingga sekarang. Di kalangan pemuda sekarang seharusnya, kemampuan berpantun biasanya dihargai. Pantun menunjukkan kecepatan seseorang dalam berfikir dan bermain-main dengan kata. Parikan ada dua warna, (dua jenis) yaitu:

1. Terdiri atas 2 kalimat yang bersajak.

2. Saben saukara kedadean saka rong gatra (larik). Dalam hal ini adalah bentuk parikan panjang

3. Ukara pertama berupa purwaka (sampiran), ukara kedua berupa uwose (isi).

Parikan Sebuah Idola Jawa Parikan merupakan kata pantun (bahasa jawa krama) sering diterjemahkan ke dalam bahasa jawa ngoko menjadi pari. Artinya berbagai hal tentang pari. Parikan berarti sejajar dengan pantun, maka di dalamnya harus ada sampiran (ancang-ancang) bicara, dan isi (kandungan) makna berikutnya. Karena parikan ini termasuk atau merupakan tradisi lisan rakyat jadi tidak jelas siapa penciptanya atau anonim. Hubungan sampiran dan isi sejajar tak ada yang lebih dominan atau penting, keduanya saling mengisi membentuk sebuah estetika. Dengan kata lain pantun dan parikan sebenarnya memiliki ciri-ciri yang senada. Keduanya memiliki struktur sampiran dan isi. Sampiran adalah kata-kata awal yang membutuhkan jawaban (isi). Sampiran dan isi harus selaras bunyi vokal dan konsonannya.

Parikan merupakan genre puisi rakyat yang khas, meskipun demikian parikan tergolong puisi jawa tradisional tembang para, artinya aturan yang digunakan tidak terlalu ketat. Parikan juga sering digunakan dalam pentas seni yaitu gara-gara wayang kulit, dagelan kethoprak, kentrung, jathilan, dan sebagainya yang dimanfaatkan sebagai wahana ekspresi. Parikan cocok 
sebagai konsumsi kejiwaan. Orang Jawa sudah membicarakan dan memanfaatkan parikan dalam ragam seni, sehingga parikan semakin digemari dan menjadi idola. Orang yang mendengarkan pun akan merasa adanya getaran-getaran jiwa yang menggores.

Berkait dengan pendidikan karakter, Hidayatullah (2010:13) memaparkan bahwa pendidikan karakter berkait dengan kualitas atau kekuatan mental seseorang yang berbeda dengan orang lain. Lebih jauh, Baedhowi mengungkapkan bahwa pendidikan karakter secara universal, antara lain (1) kedamaian (peace), (2) menghargai (respect), (3) kerja sama (cooperation), (4) kebebasan (freedom), (5) kebahagiaan (happines), (6) jujur (honesty), (7) kerendahan hati (huminity), (8) kasih sayang (love), (9) tanggung jawab (responsibility), dan (10) kesederhanaan (simplicity), (11) toeleransi (tolerance), dan (12) persatuan (unity) (Baedhowi, 2010:3). Berikut dipaparkan contoh parikan yang didalamnya merepresentasikan pendidikan karakter (Daryanto, 1999:143-144).

\subsection{Parikan Jawa Sebagai Sumber Kearifan Lokal dan Pembentuk Karakter Siswa}

Dari segi makna dan fungsi parikan ada beragam parikan dalam masyarakat jawa yaitu sebagai berikut:

\section{Manuk tuhu menclok pager}

Yen sinau mesthi pinter

Ngasah arit nganthi landhep

Dadi murid kudu sing sregep

Jemek-jemek gulo jawa

Aja sok ngenyek karo kanca

Parikan Manuk tuhu menclok pager, Yen sinau mesthi pinter (burung Tuhu hinggap di pagar, jika belajar, pasti pintar) merepresentasikan pendidikan karakter kegigihan dalam belajar. Jika belajar, pastilah pintar. Filosofi tersebut sangat dalam sebab saat ini kebanyakan murid-murid lebih suka nge-game daripada belajar. Mereka -para murid-- lebih disibukkan dengan dunia maya (facebook-an, chatting-an, BBM-an) yang sekarang sedang menjadi trend di Indonesia. Jika tidak mengikuti trend seperti itu, mereka dianggap jadul/ketinggalan zaman, kuper. Parikan Ngasah arit nganthi landhe, Dadi murid kudu sing sregep (Mengasah sabit sampai tajam, Jadi 
murid harus rajin). Parikan tersebut merepresentasikan pendidikan karakter yang berkait dengan kerajinan/keuletan dalam menimba ilmu di sekolah. Parikan Jemek-jemek gulo jawa, Aja sok ngenyek karo kanca (becek-becek gula jawa, jangan menghina sesama teman) merepresentasikan pendidikan karakter toeleransi dengan sesama teman. Dengan begitu, sesama teman mereka tidak mudah bermusuhan/bertengkar satu sama lain. Selain itu, pendidikan karakter rasa persatuan dengan sesama teman pun muncul dalam parikan tersebut.

2. Sebagai ekspresi jiwa susah

Contoh :

Kaya ngapa rasane tape

Kaya bengkoang ginawe rawon

Kaya ngapa rasane wong ora duwe

Kaya wayang gawe lakon

Parikan di atas menggambarkan keadaan jiwa seseorang yang kurang mampu. Dia amat merasakan keberadaan dirinya yang sangat kekurangan berbagai hal yang diibaratkan seperti wayang yang dibuat satu lakon dalam pementasan wayang yang harus ikut setiap gerakan sang dhalang. Yang menurutnya itu sudah tidak bisa diubah lagi, ungkapan semacam Ini merupakan pelarian agar menyenangkan diri lewat parikan.

3. Sebagai kontrol sosial

Contoh:

Tak ibaratna lampune lilin

Mobat mabit kesilir angin

Ora gampang dadi pemimpin

Dikoreksi rakyat sing miskin

Perikan tersebut ditujukan kepada pemimpin bangsa yang seharusnya simpati terhadap dunia bawah yang selalu kekurangan. Batas kesenjangan ekonomi biasanya yang menjadi bahan pijakan. Hal ini menunjukkan sebuah ekspresi protes sosial. Fungsi folklor itu amat penting sebagai alat kontrol sosial. 
4. Sebagai sindiran

Contoh:

Cecak kecemplung lenga

Tewas macak ora sida lunga

Theklek kecemplung kalen

Tinimbang golek aluwung balen

Berdasarkan makna dan fungsinya parikan tersebut merupakan sastra lisan masih mempunyai fungsi yang jelas dalam masyarakat. Namun demikian untuk memahami fungsi parikan yang tergolong sastra lisan memerlukan pemikiran yang kritis. Pemikiran kritis inilah yang diharapkan kepada siswa agar mampu mengungkapkan makna sindiran yang terdapat pada parikan tersebut.

5. Sebagai ekspresi ilmu sejati

Parikan juga ada kalanya membeberikan ilmu sejati yakni tentang kesempurnaan hidup.

Contoh parikan kentrung :

Ten pisah maring wong lanang

Randha durung peputra

Tindakane maring gunung

Welanjar durung akrama

Siti pinendhem sajroning bumi

Banyu kelem sajroning toya

Prawan ayu rupane

Parikan tersebut merupakan bentuk ilmu tua banyak menggunakan parikan yang menuju pada pencapaian hidup purna. Melalui perumpaman (isbat). Si kesut mengitari jagat dan si buta menghitung bintang adalah gambaran hidup manusia. Dengan bekal budi dan nalar akan dapat menyebabkan orang bisa tahu ilmu wadhag yaitu kosmologi jawa tentang alam semesta. Kosmologi merupakan ilmu yang mempelajari struktur dan sejarah alam semesta dalam skala besar. Orang tuna rungu memikul air dan mencari api merupakan gambaran orang jawa yang mencapai pada ngelmu yang sejati. Pada waktu mencari ilmu harus siap wadhah atau batin yang 
bersih karena bekal kebersihan atau kesucian merupakan bekal awal yang harus dibawa agar mudah dalam mencari ilmu.

\section{Sebagai estetika gending}

Fungsinya untuk memperindah alunan gending Sinom parijatha. Parikan ini sering dimanfaatkan untuk senggakan atau selingan dalam gending. Senggakan semacam itu selain dapat memperindah nuansa gending juga akan memercikan ajaran-ajaran kejawen. Makna dari senggakan tersebut merupakan ajaran moral jawa yaitu :

a. Manusia jangan mempersulit pihak lain dalam konteks diajak ora gelam ditinggal golong koming maksudnya adalah ketika orang diajak tidak mau ditinggal sakit hati, seharusnya manusia jangan pernah mempersulit pihak lain jika diajak seseorang jawab dengan jelas ya dan tidaknya jangan mempersulit atau membingungkan orang lain.

b. Diharapkan agar mempunyai jiwa yang sabar.

c. Manusia yang telah malang melintang, hal ini dimaksudkan untuk menggugah semangat bahwa orang yang berusaha keras akan memetik hasilnya yang diungkapkan dalam senggakan ngana aja ngana.

d. Merujuk pada sikap manusia hendaknya tahu diri. Hal ini dimaksudkan bahwa hubungan sosial orang Jawa sebaiknya dijaga dengan ungkapan yang mengisyaratkan bahwa hubungan sosial Jawa amat penting.

e. Sebagai penutup bicara seorang pranatacara. Orang Jawa yang berbicara di depan umum biasanya selalu anoraga (merendahkan diri). Sikap ini dimanifestasikan ke dalam parikan lisan yang khas.

Sebagai contoh:

parikan suminten sura menggala, cekap semanten atur kula,

kemudian dilanjutkan dengan parikan, salah satu contohnya sebagai berikut :

Kupat kecemplung santen

Menawi lepatnyuwun pangapunten

Kupat tercebur santan 


\section{Jika salah mohon maaf}

Parikan tersebut dalam konteks pilihan yang kata yang digunakan oleh para pranatacara cukup khas dan bermodus pada kata kupat. Kupat (ketupat) adalah bahan makanan yang dibungkus janur. Kupat juga sering muncul di tradisi lebaran, yang berkaitan pula dengan permohonan maaf. Dengan demikian pemakainan kata kupat tersebut secara kultural memang sangat mendukung estetika. Ungkapan permohonan maaf seperti itu seakan-akan telah menjadi bumbu di akhir pidato seorang pranata cara.

\subsection{Tembang Jawa Sebagai Sumber Kearifan Lokal dan Pembentuk Karakter Siswa}

Makalah ini dipilih makna istilah tembang yang terdapat dalam Kamus Besar Bahasa Indonesia (KBBI). Dalam KBBI, kata tembang memiliki dua makna, yang pertama bermakna syair yang diberi berlagu (untuk dinyanyikan), nyanyian, yang kedua bermakna puisi. Jadi, makna tembang Jawa dalam makalah ini adalah lagu Jawa sesuai pemaknaan dalam KBBI. Seperti yang ingin dicapai dalam tujuan penulisan, yaitu mengembangkan karakter diri pribadi menuju karakter bangsa melalui terjemahan syair-syair tembang Jawa dalam pengajaran bahasa dan sastra Indonesia.

Pada tembang Jawa terdapat nilai-nilai moral yang dapat diterapkan dalam kehidupan sehari-hari, terutama dalam membentuk siswa yang berkarakter. Hal itu pun berkaitan dengan konsep kearifan lokal yang kini mulai sering kita dengar.

Menurut Amir (2013), sastra lisan menyimpan kearifan lokal (local wisdom), kecendikiaan tradisonal, pesan-pesan moral, dan nilai sosial dan budaya. Semua itu tumbuh, berkembang, dan diwariskan dalam masyarakat sastra itu secara lisan. Ketika kita berbicara tentang pembangunan karakter bangsa, mestinya sastra lisan menjadi salah satu suber karakter bangsa karena karakter yang disimpan dalam sastra lisan itu sesuai dengan konteks sosial, agama, dan lingkungan kita.

Sebenarnya, ketika berbicara tentang kearifan lokal, penulis menawarkan sebuah wacana tentang pengajaran sastra di sekolah, dalam hal ini di SMP. Pengajaran sastra yang dimaksud adalah pengajaran sastra berbasis kearifan lokal, yaitu pengajaran sastra yang tidak hanya 
menggunakan pengalaman hidup masyarakat Jawa (dalam tembang Jawa) saja seperti yang akan dibahas dalam makalah ini, tetapi juga pengalaman hidup masyarakat (dalam bentuk tembang) daerah lain yang populer di kalangan anak-anak atau remaja.

Berkaitan dengan kearifan lokal, sebuah tembang Jawa dapat dijadikan contoh. Misalnya, lagu Tombo Ati.

a. Perhatikan penggalan syair "Tombo Ati" berikut ini.

Tombo ati iku lima ing wernane

Ingkang dhingin maca Quran sak maknane

Kaping pindho sholat sunat lakonana

Kaping telu wong kang sholeh kumpulana

Kaping papat kudu weteng ingkang luwe

Kaping limo dzikir wengi ingkang suwe

Sak kabehe sapa bisa anglakoni

Insya Allah huta'ala ngijabahi

Gusti Allah kang kuwasa

Gawe kewan lan manungsa

Gawe srengenge lan mbulan

Gawe bumi lan wit-witan...

Artinya:

Obat hati itu ada lima macam

Yang pertama membaca Quran dan memaknainya

Kedua menjalankan sholat sunat

Ketiga kumpul dengan orang sholeh

Keempat perut harus lapar

Kelima dzikir malam yang lama

Seluruhnya bagi yang bisa melakukan

Insya Allah huta'ala mengabulkan

Gusti Allah Maha Kuasa

Menciptakan hewan dan manusia 
Menciptakan matahari dan bulan

Menciptakan bumi dan pepohonan

$\cdots$

Pengalaman religius dapat dijadikan tema penulisan puisi karena setiap siswa bisa mendapatkannya setiap saat. Syair tersebut menyampaikan pesan religius yang dapat menyarankan kita untuk melaksanakan apa yang diperintahkan oleh yang Maha Kuasa. Syair tersebut dapat menumbuhkan karakter siswa yang religius yang selalu ingat kepada Sang Maha Pencipta, sehingga siswa dapat melakukan suatu tindakan atau perbuatan yang tidak semena-mena.

b. Perhatikan syair lagu berikut ini.

Turi-Turi Putih

Turi-turi putih ditandur neng kebon agung

Cleret tiba nyemplung kepundhung kebange apa

Mbok ira mbok ira mbo ira kembange apa

Kembang-kembang menur

Sing dakpilih kembange menur

Ayo kanca padha syukur

Kanggo sangu ning alam kubur

Mbo ira mbo ira mbo ira kembange apa

Kembang-kembang mlathi

Sing dakpilih kembang mlathi

Sing dakphilih kembang mlathi

Ayo kanca padha bekti

Sungkem marang ibu pertiwi 
Artinya:

bunga turi putih di tanam di kebun besar

Celeret jatuh tercebur kepundhung bunga apa

Mbo ira-mbo ira mbo ira bunga apa

Bunga-bunga menur

Yang kupilih bunga menur

Ayo teman syukur bersama

Sebagai bekal di alam kubur

Mbok ira mbo ira mbo ira bunga apa

Bunga-bunga melati

Yang kupilih bunga melati

Yang kupilih bunga melati

Ayo teman sama-sama berbakti

Sujud kepada ibu pertiwi”

“Turi-turi putih" menyimbolkan makna kesucian hati, terkandung pula makna religius, dan cinta tanah air yang menjadi dasar sikap toleransi siswa.

\section{SIMPULAN}

Sejak lama, sastra lisan Jawa telah menyedot perhatian orang. Karena itu, sastra lisan dipandang memeliki keunikan. Dilihat dari aspek bentuk maupun kandungan makna, sastra lisan memiliki perbedaan dengan sastra tulis. Peranan sastra lisan dalam pembentukan budaya masyarakat Jawa sangat menonjol. Karena sastra lisan jawa merupakan warisan leluhur, di dalamnya tertanam pesan leluhur yang istimewa. Dengan demikian, kekuatan sastra lisan Jawa memang benar-benar memberikan efek filosofis yang mendalam bagi masyarakat Jawa (sebagai masyarakat kolektif)

Sastra lisan Jawa sangatlah penting dalam kaitannya dengan pembentukan karakter pada anak siswa/siswi di sekolah. Karena itu, diharapkan, ada sinergi antara guru, murid, masyarakat, 
dan penentu kebijakan dalam kaitannya dengan pembelajaran sastra lisan di sekolah. Jika sastra lisan Jawa diajarkan di sekolah, anak-anak akan mengenal secara implisit/eksplisit representasi pendidikan karakter yang ada di sekolah. Dengan demikian, akan terbentuk karakter yang cerdas, beretika, dan beriman.

\section{DAFTAR PUSTAKA}

Ahmadi, Anas. Pembelajaran Sastra Lisan Jawa di Sekolah sebagai Alternatif Pembentukan Karakter. Artikel Dosen Bahasa dan Sastra Indonesia, Universitas Negeri Surabaya.

Amir, Adriyetti. 2013. Sastra Lisan Indonesia. Yogyakarta: ANDI.

Endraswara, E. 2005. Tradisi Lisan Jawa. Yogyakarta: Narasi.

Rosidi, Ajib. 1995. Sastra dan Budaya: Kedaerahan dalam Keindonesian. Yogyakarta: Pustaka Pelajar.

Soehardi. Nilai-nilai Tradisi Lisan dalan Budaya Jawa. Jurnal Media Pendidikan dan Ilmu Pengetahuan 20 (10):1-10. 


\title{
MODEL PEMBELAJARAN BAHASA DAN SASTRA INDONESIA BERBASIS KEARIFAN LOKAL
}

\author{
Wina Wulandari \\ Pendidikan Bahasa Indonesia \\ Pascasarjana Universitas Negeri Medan
}

\begin{abstract}
Abstrak
Pembelajaran bahasa dan sastra Indonesia merupakan kegiatan yang penting dalam kehidupan manusia yang mengaitkan antara lingkungan atau budaya sekitar. Pada dasarnya pendidikan merupakan bagian yang sangat penting dan tidak terpisahkan dari perjalanan manusia. Melalui pendidikan, kualitas sumber daya manusia dapat semakin meningkat seiring dengan meningkatnya pendidikan yang diperolehnya. Kualitas tersebut akan sangat dibutuhkan dalam persaingan untuk memperoleh sebuah peran dalam memasuki kehidupan global, untuk meraih kesejahteraan hidup. Di Indonesia sendiri, pendidikan mengalami berbagai macam perubahan yang dapat dilihat dari kurikulum yang argumentasinya lebih kepada kurikulum tersebut perlu diganti karena tidak sesuai dengan zaman atau era yang sedang terjadi sehingga diperlukan suatu pembaharuan. Secara umum tujuan penulisan ini adalah mendeskripsikan model pembelajaran bahasa dan satra Indonesia berbasis kearifan lokal. Materi pembelajaran yang dipilih untuk diajarkan oleh guru dan harus dipelajari siswa hendaknya berisikan pembelajaran yang benar-benar menunjang tercapainya standar kompetensi dan kompetensi dasar. Hasil penelitian yang diperoleh adalah menciptakan pembelajaran yang berbasis kearifan lokal pendidik harus mengetahui tentang hal-hal yang dapat menunjang keberhasilan dalam proses belajar salah satunya yaitu mengetahui pembelajaran dan sumber belajar.
\end{abstract}

\section{A. PENDahuluan}

Banyak guru yang beranggapan

bahwa pembelajaran memiliki peran penting dalam ruang lingkup pendidikan. Pendidikan merupakan bagian yang sangat penting dan tidak terpisahkan dari perjalanan hidup manusia. Melalui pendidikan, kualitas sumber daya manusia dapat semakin meningkat seiring dengan meningkatnya pendidikan yang diperolehnya. Kualitas tersebut akan sangat dibutuhkan dalam persaingan untuk memperoleh sebuah peran dalam memasuki kehidupan global, untuk meraih kesejahteraan hidup. Dalam hal ini, pemerintah telah memberikan rambu-rambu 
dalam penyelenggaraan pendidikan di Indonesia melalui berbagai macam kebijakan, antara lain tertuang dalam perundang-undangan.

Undang-Undang Sistem Pendidikan Nasional No. 20 Tahun 2003 Bab II Pasal 3 menyatakan bahwa tujuan pendidikan nasional adalah mengembangkan potensi peserta didik agar menjadi manusia yang beriman dan bertakwa kepada Tuhan Yang Maha Esa, berakhlak mulia, sehat, berilmu, cakap, kreatif, mandiri dan menjadi warga negara yang demokratis dan bertanggung jawab.

Sistem pendidikan nasional dalam abad ke 21 menghadapi berbagai tantangan dalam mempersiapkan generasi penerus bangsa yang berkualitas dan berdaya saing. Pembangunan karakter bangsa merupakan bagian penting dan tidak terpisahkan dari pembangunan nasional. Kebijakan nasional pembangunan karakter bangsa ini disusun sebagai pelaksanaan amanat UU RI No. 17 tahun 2007 tentang Rencana Pembangunan Jangka Panjang Nasional Tahun 2005-2025.

Pembangunan karakter bangsa adalah misi pertama dari delapan misi guna mewujudkan visi pembangunan nasional. Secara eksplisit keberhasilan pembangunan karakter bangsa ditandai dengan terbentuknya karakter bangsa yang tangguh, kompetitif, berakhlak mulia, bermoral, bertoleran, bergotong royong, patriotik, dinamis, berbudaya dan berorientasi iptek berdasarkan pancasila dijiwai oleh iman dan takwa kepada Tuhan Yang Maha Esa (Kemendiknas, 2010).

Kearifan budaya lokal dapat diinternalisasikan dalam pendidikan karena dia memiliki banyak kelebihan. Kelebihan tersebut antara lain sebagai berikut: (1) Kearifan budaya lokal dapat menjadi sarana pembelajaran bagi setiap manusia untuk menjadi orang yang cerdas, pandai, dan bijaksana, (2) Kearifan budaya lokal memiliki nilai-nilai positif untuk ditransformasikan kepada peserta didik guna membentuk kepribadian positif. Sebagaimana Sayuti (2009) mengemukakan bahwa budaya dan potensi lokal itu meniscayakan fungsi yang strategis bagi pembentukan karakter dan identitas.

Atas dasar hal tersebut, selayaknyalah kearifan budaya lokal diintegrasikan dalam model pembelajaran bahasa dan sastra Indonesia memberi inspirasi bahan pembelajaran yang berfungsi untuk membentuk karakter dan identitas siswa. Berdasarkan pada uraian 
tersebut, perlu dilakukan pengujian untuk membuktikan bahwa model pembelajaran bahasa dan sastra Indonesia berbasis kearifan budaya lokal yang berorientasi pendidikan karakter lebih efektif.

Sehubungan dengan itu, masalah Melihat hal ini, maka peneliti tertarik untuk menyusun penulisan dengan memperhatikan permasalahan tersebut maka judulnya penulisan ini adalah " Model pembelajaran Bahasa dan Satra Indonesia berbasis kearifan lokal. Dalam penulisan ini, peneliti akan mendsekripsikan serta memperhatikan model yang bagaimana implementasikan di sekolah yang harus di kuasai oleh guru atau calon-calon perubahan agar dapat menjadi bekal bagi mereka kedepannya.

\section{B. KAJIAN TEORETIS}

\section{A. Pengertian Model}

Pemahaman model dapat dipahami dengan berbagai macam pengertian yang bermacam-macam. Secara etimologi, model berasal dari bahasa italia yakni modello yang dapat diartikan dari berbagai dimensi, jika dari kata benda maka model diartikan sebagai jenis atau contoh, sedangkan dari kata sifat dapat dipahami sebagai teladang atau di ambil sebagai contoh dan yang terakhir dari kata kerja dipahami sebagai membuat dengan contoh. Dengan kata lain, model secara etimologi yakni sesuatu contoh. Dalam kamus besar bahasa indoneis (KBBI), model didefinisikan sebagai pola dari sesuatu yang dibuat atau yang dihasilkan atau barang tiruan. Maka dapat diambil kesimpulan, jika model dapat dipahami sebagai suatu jenis contoh dari suatu pola ( contoh, acuan, ragam dsb) yang dibuat untuk menghasilkan sesuatu.

Sedangkan Pembelajaran merupakan suatu rangkaian kegiatan untuk memungkinkan terjadinya proses belajar yang dirancang, dilaksanakan dan dievaluasi secara sistematis agar dapat mencapai tujuan pembelajaran tersebut secara aktif, efektif dan inovatif.

Pada model pembelajaran menurut Zaini, model pembelajaran adalah pedoman berupa program atau petunjuk strategi mengajar yang dirancang untuk mencapai suatu tujuan pembelajaran. Pedoman itu memuat tangguangjawab guru dalam merencanakan, melaksanakan dan mengevaluasi kegiatan pembelajaran. Salah satu tujuan dari penggunaan model pembelajaran adalah untuk meningkatkan kemampuan siswa selama belajar.

Menurut Sukmasari Model pembelajaran adalah suatu rencana mengajar yang melibatkan pola pembelajaran tertentu. 
Dalam pola tersebut dapat terlihat kegiatan guru, siswa, sumber belajar yang digunakan di dalam mewujudkan kondisi belajar atau sistem lingkungan yang menyababkan terjadinya belajar pada siswa.

Dari berbagai macam pengertian diatas maka dapat diambil kesimpulan model pembelajaran adalah suatu pola yang dijadikan pedoman dalam startegi mengajar untuk mencapai suatu tujuan pembelajaran.

\section{B. PENGERTIAN PEMBELAJARAN}

Menurut undang-Undang Sistem Pendidikan Nasional No. 20 Tahun 2003 menyatakan pembelajaran adalah "proses interaksi peserta didik dengan pendidik dan sumber belajar pada suatu lingkungan belajar". Pembelajaran sebagai proses belajar yang dibangun oleh guru untuk mengembangkan kreatifitas berpikir yang dapat meningkatkan kemampuan berpikir siswa, serta dapat meningkatkan kemampuan mengkontruksikan pengetahuan baru sebagai upaya meningkatkan penguasaan yang baik terhadap materi pelajaran.

\section{Menurut Gagne dan Briggs}

(1979:3) Pengertian pembelajaran adalah suatu sistem yang bertujuan untuk membantu proses belajar siswa, yang berisi serangkaian peristiwa yang dirancang, disusun sedemikian rupa untuk mempengaruhi dan mendukung terjadinya proses belajar siswa yang bersifat internal.

Sugandi, dkk (2004:9) Menyatakan bahwa pembelajaran terjemahan dari kata "instruction" yang berarti self instruction (dari internal) dan eksternal instructions (dari eksternal). Pembelajaran yang bersifat eksternal antara lain datang dari guru yang disebut teacing atau pengajaran. Dalam pembelajaran yang bersifat eksternal prinsip-prinsip belajar dengan sendirinya akan menjadi prinsip-prinsip pembelajaran.

Pengertian ini menggambarkan bahwa Pembelajaran merupakan aspek kegiatan manusia yang kompleks yang tidak sepenuhnya dapat dijelaskan. Pembelajaran secara simpel dapar diartikan sebagai produk interaksi berkelanjutan antara pengembangan dan pengalaman hidup. Pembelajaran dalam makna kompleks adalah usaha sadar dari seorang guru untuk membelajarkan siswanya "mengarahkan interaksi siswa dengan sumber lainnya" dalam rangkan mencapai tujuan yang diharapkan.

\section{Menurut Sanjaya (2011:13-14)}

Pembelajaran merupakan suatu sistem yang kompleks yang keberhasilannya dapat dilihat dari dua aspek yaitu aspek produk dan aspek proses. Keberhasilan 
pembelajaran dilihat dari sisi produk adalah keberhasilan siswa mengenai hasil yang diperoleh dengan mengabaikan proses pembelajaran. Hal ini menunjukkan bahwa dalam pembelajaran diharapkan siswa benar-benar merasakan manfaat pembelajaran itu setelah ia mempelajarinya.

\section{Komalasari}

(2013:3)

menambahkan bahwa Pembelajaran merupakan suatu sistem atau proses membelajarkan pembelajar yang direncanakan, dilaksanakan dan dievaluasi secara sistematis agar pembelajar dapat mencapai tujuan-tujuan pembelajaran secara efektif dan efesien. Pembelajaran merupakan sumber berupa visual maupun audiovisual yang dapat digunakan sebagai saluran alternatif pada komunikasi di dalam proses pembelajaran.

Berdasarkan kajian di atas, istilah pembelajaran yang digunakan dalam penelitian ini adalah suatu pembelajaran yang disusun secara sistematis yang digunakan guru dan siswa dalam pengajaran bahasa Indonesia di sekolah untuk mencapai tujuan yang diharapkan.

\section{MODEL PEMBELAJARAN}

Model pembelajaran merupakan kerangka konseptual atau pola suatu pembelajaran. Kerangka konseptual atau pola tersebut dirancang untuk melaksanakan suatu pembelajaran yang di dalamnya tercakup tujuan-tujuan pengajaran, tahap-tahap dalam kegiatan pembelajaran, lingkungan pembelajaran, dan pengelolaan kelas. Semua unsur tersebut disusun secara sistematis untuk mengorganisasikan pengalaman belajar dalam rangka mencapai tujuan pembelajaran. Rancangan ini menjadi pedoman guru dalam mempersiapkan dan melaksanakan kegiatan belajar mengajar. Model ini dibuat dengan tujuan untuk membantu guru dalam mengaplikasikan kurikulum, mengembangkan materi ajar, dan melaksanakan pembelajaran di kelas. Sebagaimana Brady (1985: 7) dalam Aunurrahman (2009: 146) mengemukakan bahwa model pembelajaran dapat diartikan sebagai blueprint yang dapat digunakan untuk membimbing guru di dalam mempersiapkan dan melaksanakan pembelajaran.

\section{KEARIFAN LOKAL}

Secara umum local wisdom (kearifan setempat) dapat dipahami sebagai gagasan-gagasan setempat (local) yang bersifat bijaksana, penuh 
kearifan, bernilai baik, yang tertanam dan diikuti oleh anggota masyarakatnya. Sedangkan, yang dimaksud kearifan budaya adalah seluruh usaha dan hasil usaha manusia atau masyarakat yang dilakukan dan ditujukan untuk memberikan makna manusiawi dan membuat tata kehidupan manusiawi pula. Dalam rangka memenuhi kebutuhan hidupnya, usaha dan hasil budaya manusia diarahkan untuk meningkatkan harkat dan nilai-nilai luhur kemanusiaan.

\section{E. METODE PENELITIAN}

Setiap penelitian memiliki pendekatan yang berbeda-beda, bergantung pada metode yang digunakan masingmasing. Pendekatan yang digunakan dalam tulisan ini adalah penelitian kualitatif deskriptif. Penelitian kualitatif merupakan penelitian yang bermaksud untuk memahami fenomena tentang apa yang dialami oleh subjek penelitian, misalnya perilaku, persepsi, motivasi, tindakan, dan lainlain. Pendekatan penelitian kualitatif ditentukan oleh karakter penelitian kualitatif, yang tentu berbeda dengan karakter penelitian kuantitatif.

Dilihat dari ruang lingkupnya, penelitian kualitatif dibagi ke dalam dua cakupan, yakni penelitian kepustakaan (library research) dan penelitian lapangan (field research). Penelitian kepustakaan mengandalkan data-data yang hampir sepenuhnya dari perpustakaan, sehingga penelitian ini lebih populer dikenal dengan penelitian kualitatif deskriptif kepustakaan atau penelitian bibliografis. Selain itu, penelitian kepustakaan sering juga diistilahkan dengan penelitian non-reaktif, karena sepenuhnya hanya mengandalkan data-data yang bersifat teoritis dan dokumentasi yang ada di perpustakaan. Sementara itu, penelitian lapangan mengandalkan data-datanya di lapangan (social setting) yang diperoleh melalui informan dan data-data dokumentasi yang berkaitan dengan subjek penelitian.

Penelitian pustaka atau studi pustaka tidak hanya sekadar urusan membaca dan mencatat literatur atau buku-buku. Penelitian pustaka merupakan rangkaian kegiatan yang berkenaan dengan metode pengumpulan data pustaka, membaca dan mencatat serta mengolah bahan penelitian. Adapun dalam tulisan ini, jenis penelitian yang digunakan adalah penelitian kualitatif deskriptif kepustakaan atau penelitian bibliografis, karena mengandalkan teoriteori dari buku sebagai literatur. 


\section{F. HASIL DAN PEMBAHASAN}

\section{A. Model Pembelajaran Bahasa Dan} Sastra Indonesia Berbasis

\section{Kearifan Lokal}

Dalam dunia pendidikan seringkali

kita menemukan berbagai masalah dalam berbagai hal yang menyangkut tentang pengajaran, pembelajaran dan proses dalam suatu pembelajaran itu sendiri, salah satunya yaitu penggunaan metode pengajaran yang monoton dapat menjadian siswa sulit untuk menangkap berbagai informasi ataupun materi yang disampaikan. Baik pembelajaran secara indoor maupun outdoor. Guru pun sering tidak memperhatikan metode yang digunakan apakah metode tersebut sesuai dengan pembelajaran yang terkait atau tidak, sebagian guru juga sering menggunakan satu metode pembelajaran untuk semua mata pelajaran, yang akibatnya siswa sering tidak merespon apa yang disampaikan oleh guru. Untuk menunjang keberhasilan dalam suatu proses pembelajaran guru dan siswa dituntut untuk selalu aktif dalam suatu pembelajaran yang berlangsung, seringkali guru yang aktif dan siswanya pun tidak mempunyai feedback terhadap apa yang disampaikan oleh guru. Untuk membangun metode pembelajaran yang berbasis kearifan lokal guru dituntut untuk bisa memahami tingkat kemampuan siswa agar siswa dapat menumbuhkan sifat rasa percaya dirinya dan terdorong untuk mengikuti proses pembelajaran dengan baik.

Pelaksanaan model pembelajaran bahasa dan sastra Indonesia berbasis kearifan lokal memiliki pembelajaran yang menghubungkan media pembelajaran yang berupa contoh buku harian, tayangan power point untuk menjelaskan materi dan menghubungi toho atau anggota masyarakat dalam kearifan budaya lokal.

Kearifan budaya lokal selain memiliki nilai-nilai yang positif ternyata dapat membantu untuk meningkatkan kompetensi pembelajaran siswa yang negatif menjadi positif. Kompetensi pembelajaran meningkat disebabkan sumber inspirasi yang berasal dari kearifan budaya lokal lebih mudah dipahami dan telah dikenali oleh siswa.

Untuk menciptakan pembelajaran yang berbasis kearifan lokal pendidik harus mengetahui tentang hal-hal yang dapat menunjang keberhasilan dalam proses belajar salah satunya yaitu mengetahui budaya-budaya lokal khususnya pada budaya Sumatera Utara (Melayu Deli) dan sumber belajar. Jika dipahami secara rinci model pembelajaran dan sumber belajar itu 
berbeda pada segala sesuatu (benda, data, fakta, ide dll) yang bisa menimbulkan proses belajar yang memiliki keterkaitan dengan kebuayaan lokal.

Terdapat berbagai unsur-unsur model pembelajaran berbasis kearifan lokal khususnya pada budaya melayu yang harus dipahami yaitu :

1) Petunjuk belajar yaitu komponen utama yang meliputi petunjuk bagi pendidik maupun peserta didik yang didalamnya dijelaskan tentang bagaimana pendidik sebaiknya mengajarkan materi yang berkaitan kerarifan lokal kepada peserta didik dan sebagaiman pula peserta didik sebaiknya mempelajari materi yang ada dalam pembelajaran tersebut.

2) Kompetensi yang akan dicapai maksud dari komponen tersebut adalah kompetensi yang akan dicapai oleh siswa. Pendidik harus menjelaskan dan mencantumkan dalam pembelajaran yang sudah disusun dengan standart kompetensi, kompetensi dasar, maupun indikator pencapaian hasil belajar yang harus dikuasai peserta didik.

3) Informasi pendukung merupakan berbagai informasi tambahan yang dapat melengkapi pembelajaran, sehingga peserta didik akan semakin mudah menguasai pengetahuan yang akan mereka peroleh.

4) Latihan-latihan merupakan suatu bentu tuga yang diberikan peserta didik untuk melatih kemampuan siswa setelah mempelajari pembelajaran yang berkaitan dengan kearifan lokal budaya khususnya pada budaya melayu deli.

5) Petunjuk kerja atau lembar kerja adalah suatu lembar atau beberapa lembar kertas yang berisi sejumlah langkah prosedural cara pelaksanaan aktivitas atau kegiatan tertentu yang harus dilakukan peserta didik berkaitan dengan praktik dan sebagainya.

6) Evaluasi dalam komponen evaluasi terdapat sejumlah pertanyaan yang ditujukan kepada peserta didik untuk mengukur seberapa jauh penguasaan kompetensi yang berhasil mereka kuasai setelah mengikuti proses pembelajaran.

\section{PENUTUP}

Model pembelajaran adalah suatu rencana mengajar yang melibatkan pola pembelajaran tertentu. Dalam pola tersebut dapat terlihat kegiatan guru, siswa, sumber 
belajar yang digunakan di dalam mewujudkan kondisi belajar atau sistem lingkungan yang menyababkan terjadinya belajar pada siswa.

Pembelajaran merupakan kombinasi yang tertata meliputi segala unsur manusiawi, perlengkapan, fasilitas, prosedur yang saling mempengaruhi dalam mencapai tujuan dari pembelajaran.

Kearifan budaya lokal khusunya pada budaya melayu deli selain memiliki nilai-nilai yang positif ternyata dapat membantu untuk meningkatkan kompetensi pembelajaran karakter siswa yang negatif menjadi positif. Guru meningkat kemampuan siswa disebabkan sumber inspirasi yang berasal dari kearifan budaya lokal lebih mudah dipahami dan telah dikenali oleh siswa sebelumnya.

\section{DAFTAR PUSTAKA}

Aunurrahman. 2009. Belajar dan Pembelajaran. Bandung: Alfabeta.

BSNP. 2006. Kurikulum Bahasa Indonesia. Jakarta

Ghazali, A.Syakur. 2010. Pembelajaran Keterampilan Berbahasa dengan Pendekatan Komutatif Interaktif. Bandung: PT.Refika Aditama. Guru Profesional: Implementasi Kurikulum
Tingkat Satuan Pendidikan (KTSP) dan Sukses dalam Sertifikasi Guru.

Sanjaya, Wina. 2011. Strategi Pembelajaran Berorientasi Standar Proses Pendidikan. Jakarta: Kencana.

Sunendar. 2011. Strategi Pembelajaran Bahasa. Bandung: PT. Remaja Rosdakarya.

Sayuti, Suminto A. 2009. Makalah yang disumbangkan untuk Pendidikan Kesadaran Bela Negara bagi Pemuda Tingkat Nasional Tahun 2009, Kementerian Negara Pemuda dan Olahraga bekerja sama dengan Departemen Pertahanan, 25 Maret 2009. 


\title{
MODEL PEMBELAJARAN BAHASA DAN SASTRA INDONESIA YANG IDEAL
}

Oleh : Yogi Andrian Zunaedy

\author{
Program Pascasarjana Pendidikan Bahasa Dan Sastra Indonesia \\ Universitas Negeri Medan
}

\begin{abstract}
Abstrak
Pendidikan merupakan bagian yang sangat penting dan tidak terpisahkan dari perjalanan hidup manusia. Melalui pendidikan, kualitas sumber daya manusia dapat semakin meningkat seiring dengan meningkatnya pendidikan yang diperolehnya. Kualitas tersebut akan sangat dibutuhkan dalam persaingan untuk memperoleh sebuah peran dalam memasuki kehidupan global, untuk meraih kesejahteraan hidup. Di Indonesia sendiri, pendidikan mengalami berbagai macam perubahan yang dapat dilihat dari kurikulum yang argumentasinya lebih kepada kurikulum tersebut perlu diganti karena tidak sesuai dengan zaman atau era yang sedang terjadi sehingga diperlukan suatu pembaharuan. Secara umum tujuan penulisan ini adalah mendeskripsikan model pembelajaran bahasa dan satra Indonesia yang ideal. Materi pembelajaran yang dipilih untuk diajarkan oleh guru dan harus dipelajari siswa hendaknya berisikan pembelajaran yang benarbenar menunjang tercapainya standar kompetensi dan kompetensi dasar. Hasil penelitian yang diperoleh adalah menciptakan pembelajaran yang ideal pendidik harus mengetahui tentang hal-hal yang dapat menunjang keberhasilan dalam proses belajar salah satunya yaitu mengetahui pembelajaran dan sumber belajar.
\end{abstract}




\begin{abstract}
Education is a very important part and an integral part of human life. Through education, the quality of human resources can be increased with increasing education acquired. These qualities will be sorely needed in the competition to gain a role in entering the global life, to achieve the welfare of the living. In Indonesia alone, education is experiencing a wide variety of changes that can be seen from the curriculum the curriculum more views need to be replaced because it didn't fit with the period or era is going on so that the required an renewal. In general the purpose of this writing is to describe a model of language learning materials and the ideal Indonesia dealerships and innovative. The learning materials are chosen to be taught by teachers and students to learn should contain materials or materials that really support the achievement of a standard of competence and basic competence.

The research results obtained are creating innovative learning materials that educators need to know about the things that support success in the learning process is one that is knowing the learning materials and learning resources.

\section{Kata Kunci : Model Pembelajaran Bahasa dan Sastra Indonesia, Ideal, dan Inovatif}




\section{A. PENDAHULUAN}

Pendidikan merupakan bagian yang sangat penting dan tidak terpisahkan dari perjalanan hidup manusia. Melalui pendidikan, kualitas sumber daya manusia dapat semakin meningkat seiring dengan meningkatnya pendidikan yang diperolehnya. Kualitas tersebut akan sangat dibutuhkan dalam persaingan untuk memperoleh sebuah peran dalam memasuki kehidupan global, untuk meraih kesejahteraan hidup. Dalam hal ini, pemerintah telah memberikan rambu-rambu dalam penyelenggaraan pendidikan di Indonesia melalui berbagai macam kebijakan, antara lain tertuang dalam perundang-undangan.

Undang-Undang Sistem Pendidikan Nasional No. 20 Tahun 2003 Bab II Pasal 3 menyatakan bahwa tujuan pendidikan nasional adalah mengembangkan potensi peserta didik agar menjadi manusia yang beriman dan bertakwa kepada Tuhan Yang Maha Esa, berakhlak mulia, sehat, berilmu, cakap, kreatif, mandiri dan menjadi warga negara yang demokratis dan bertanggung jawab.

Sistem pendidikan Nasional dalam abad ke 21 menghadapi berbagai tantangan dalam mempersiapkan generasi penerus bangsa yang berkualitas dan berdaya saing. Pembangunan karakter bangsa merupakan bagian penting dan tidak terpisahkan dari pembangunan nasional. Kebijakan nasional pembangunan karakter bangsa ini disusun sebagai pelaksanaan amanat UU RI No. 17 tahun 2007 tentang Rencana Pembangunan Jangka Panjang Nasional Tahun 2005-2025.

Pembangunan karakter bangsa adalah misi pertama dari delapan misi guna mewujudkan visi pembangunan nasional. Secara eksplisit keberhasilan pembangunan karakter bangsa ditandai dengan terbentuknya karakter bangsa yang tangguh, kompetitif, berakhlak mulia, bermoral, bertoleran, bergotong royong, patriotik, dinamis, berbudaya dan berorientasi iptek berdasarkan pancasila dijiwai oleh iman dan takwa kepada Tuhan Yang Maha Esa (Kemendiknas, 2010).

Kebijakan Nasional pembangunan karakter bangsa ini sesuai Permendikbud No. 54 Tahun 2013 tentang Kompetensi Lulusan harus memiliki sikap, pengetahuan, dan keterampilan. Sikap memiliki perilaku yang mencerminkan sikap orang beriman, berakhlak mulia, berilmu, percaya diri, dan bertanggung jawab dalam berinteraksi secara efektif dengan lingkungan sosial dan alam dalam jangkauan pergaulan dan keberadaannya. Pelaksanaan pendidikan kepribadian atau karakter diatur dalam Peraturan Pemerintah Nomor 19 Tahun 2005 tentang Standar Nasional Pendidikan Pasal 7 Nomor 2 yakni pada setiap tingkat pendidikan dilaksanakan melalui muatan dan atau kegiatan agama, akhlak mulia, 
kewarganegaraan, bahasa, seni dan budaya, dan pendidikan jasmani. Permendiknas tersebut menjelaskan bahwa salah satu cara mendidik kepribadian atau karakter melalui muatan bahasa.

Zaman sekarang, pendidikan merupakan batu pijakan untuk mencapai suatu negara dan bangsa yang berkualitas baik itu di lihat dari aspek psikomotorik, afektif serta kognitif yang dimiliki oleh individu dalam suatu kelompok atau masyarakat. Sehingga diperlukan suatu pendidikan yang mengairahkan dan menarik perhatian suatu individu agar dapat mengembangkan ketiga aspek tersebut agar tercapainya kualitas dari suatu bangsa dan negara.

Di Indonesia sendiri, pendidikan mengalami berbagai macam perubahan yang dapat dilihat dari kurikulum yang argumentasinya lebih kepada kurikulum tersebut perlu diganti karena tidak sesuai dengan zaman atau era yang sedang terjadi sehingga diperlukan suatu pembaharuan. Selain itu, Pendidikan di era-modern di tuntut dengan suatu hal yang baru, hal ini di karenakan dalam pengajaran suatu pembelajaran di suatu sekolah secara khusus berbeda-beda tergantung dari materi, media dan metode yang digunakan. Pengajaran yang konvensional saat ini membuat siswa merasa jenuh akan proses pembelajaran sehingga diperlukan suatu pembelajaran yang menarik perhatian siswa khususnya pada pendidikan sekolah dasar.

Melihat kondisi tersebut khususnya pendidikan di indonesia yang mengalami perubahan serta untuk dapat menarik perhatian siswa khususnya pada mata pelajaran bahasa indonesia maka diperlukan suatu model yang pas atau sesuai dengan materi atau topik yang sedang di bahas agar dapat menjadi suatu konsen bagi siswa di sekolah

Melihat hal ini, maka kami tertarik untuk menyusun penulisan dengan memperhatikan permasalahan tersebut maka judulnya penulisan ini adalah “ Model Pembelajaran Bahasa dan Satra Indonesia yang ideal. Dalam penulisan ini, peneliti akan mendsekripsikan serta memperhatikan model yang bagaimana implementasikan di sekolah yang harus di kuasai oleh guru atau calon-calon perubahan agar dapat menjadi bekal bagi mereka kedepannya.

\section{B. KAJIAN TEORETIS}

\section{Pengertian Model}

Pemahaman model dapat dipahami dengan berbagai macam pengertian yang bermacam-macam. Secara etimologi, model berasal dari bahasa italia yakni modello yang dapat diartikan dari berbagai dimensi, jika dari kata benda maka model diartikan sebagai jenis 
atau contoh, sedangkan dari kata sifat dapat dipahami sebagai teladang atau di ambil sebagai contoh dan yang terakhir dari kata kerja dipahami sebagai membuat dengan contoh. Dengan kata lain, model secara etimologi yakni sesuatu contoh. Dalam kamus besar bahasa indoneis (KBBI), model didefinisikan sebagai pola dari sesuatu yang dibuat atau yang dihasilkan atau barang tiruan. Maka dapat diambil kesimpulan, jika model dapat dipahami sebagai suatu jenis contoh dari suatu pola ( contoh, acuan, ragam dsb) yang dibuat untuk menghasilkan sesuatu.

Sedangkan Pembelajaran merupakan suatu rangkaian kegiatan untuk memungkinkan terjadinya proses belajar yang dirancang, dilaksanakan dan dievaluasi secara sistematis agar dapat mencapai tujuan pembelajaran tersebut secara aktif, efektif dan inovatif.

Pada model pembelajaran menurut Zaini, model pembelajaran adalah pedoman berupa program atau petunjuk strategi mengajar yang dirancang untuk mencapai suatu tujuan pembelajaran. Pedoman itu memuat tangguangjawab guru dalam merencanakan, melaksanakan dan mengevaluasi kegiatan pembelajaran. Salah satu tujuan dari penggunaan model pembelajaran adalah untuk meningkatkan kemampuan siswa selama belajar.

Menurut Sukmasari Model pembelajaran adalah suatu rencana mengajar yang melibatkan pola pembelajaran tertentu. Dalam pola tersebut dapat terlihat kegiatan guru, siswa, sumber belajar yang digunakan di dalam mewujudkan kondisi belajar atau sistem lingkungan yang menyababkan terjadinya belajar pada siswa.

Dari berbagai macam pengertian diatas maka dapat diambil kesimpulan model pembelajaran adalah suatu pola yang dijadikan pedoman dalam startegi mengajar untuk mencapai suatu tujuan pembelajaran.

Menurut Kemp et al.(1994), pengembangan pembelajaran merupakan suatu siklus yang kontinum. Pengembangan model pembelajaran ini dapat dimulai dari langkah manapun sesuai dengan siklus tersebut. Oleh karena itu, model pembelajaran ini dapat memberi kesempatan kepada para pengembang untuk dapat memulai dari langkah manapun sesuai dengan kurikulum yang berlaku. Beberapa langkah dalam penyusunan pembelajaran (dalam Kemp et al, 1994), yaitu.

1. Identifikasi Masalah Pembelajaran (Instructional Problems)

Mengidentifikasi adanya kesenjangan antara tujuan dalam kurikulum yang berlaku dengan fakta yang terjadi dilapangan.

2. Analisis Karakteristik Siswa (Leaner Characteristics)

Mengetahui karakteristik siswa yang meliputi ciri, kemampuan, dan pengalaman baik individual maupun berkelompok.

3. Analisis Tugas (Task Analysis) 
Merinci isi mata pelajaran dalam bentuk garis besar untuk menguasai isi bahan kajian atau mempelajari keterampilan yang mencakup keterampilan kognitif, keterampilan psikomotor, dan keterampilan sosial.

4. Merumuskan Indikator (Instructional Objectives)

Mendesain kegiatan pembelajaran, kerangka kerja dalam mengevaluasi hasil belajar siswa dan panduan siswa dalam belajar.

5. Menyusun Materi Pembelajaran (Content Squencing)

Mengurutkan isi pokok bahasan berdasarkan pengetahuan prasyarat, familiaritas, kesukaran, minat serta perkembangan siswa.

6. Strategi Pembelajaran (Instructional Strategies)

Memilih strategi belajar mengajar yang sesuai dengan tujuan.

7. Pemilihan Media atau Sumber pembelajaran (Instructional Delivery)

Tujuan dari langkah ini adalah untuk memilih media atau sumber pembelajaran sesuai dengan tuntutan tujuan pembelajaran. Keberhasilan pembelajaran sangat tergantung pada penggunaan sumber pembelajaran dan media yang dipilih.

8. Instrumen Penilaian (Evaluation Instrument)

Menyusun instrumen penilaian untuk menilai hasil belajar yang disusun berdasarkan tujuan pembelajaran khusus yang telah dirumuskan sehingga kriteria yang digunakan adalah penilain acuan patokan.

9. Sumber Pembelajaran (Instructional Resources)

Melihat ketersediaan secara komersial, biaya pengadaan, waktu untuk menyediakannya serta menyenangkan bagi siswa dalam membuat media atau sumber pembelajaran.

10. Pelayanan Pendukung (Support Services)

Menentukan keberhasilan pengembangan bahan ajar dengan memperhatikan ketersediaan anggaran, fasilitas, bahan, perlengkapan, kemampuan staf, pengajar, perancang pembelajaran, pakar, dan lain sebagainya

11. Evaluasi Formatif (Formative Evaluation)

Penilaian yang dilakukan setiap selesai satu unit proses pembelajaran untuk memberi informasi kepada pengajar atau tim pengembang seberapa baik program ini mencapai sasaran.

12. Penilaian Sumatif (Summative Evaluation)

Penilaian yang digunakan untuk menilai sejauhmana tujuan instruksional telah dicapai di akhir program pembelajaran. 


\section{Revisi Perangkat Pembelajaran (Revision)}

Mengevaluasi dan memperbaiki perangkat pembelajaran yang dikembangkan. secara terus menerus pada setiap langkah pengembangannya.

\section{Pengertian Pembelajaran}

Menurut undang-Undang Sistem Pendidikan Nasional No. 20 Tahun 2003 menyatakan pembelajaran adalah "proses interaksi peserta didik dengan pendidik dan sumber belajar pada suatu lingkungan belajar". Pembelajaran sebagai proses belajar yang dibangun oleh guru untuk mengembangkan kreatifitas berpikir yang dapat meningkatkan kemampuan berpikir siswa, serta dapat meningkatkan kemampuan mengkontruksikan pengetahuan baru sebagai upaya meningkatkan penguasaan yang baik terhadap materi pelajaran.

Menurut Gagne dan Briggs (1979:3) Pengertian pembelajaran adalah suatu sistem yang bertujuan untuk membantu proses belajar siswa, yang berisi serangkaian peristiwa yang dirancang, disusun sedemikian rupa untuk mempengaruhi dan mendukung terjadinya proses belajar siswa yang bersifat internal.

Sugandi, dkk (2004:9) Menyatakan bahwa pembelajaran terjemahan dari kata "instruction" yang berarti self instruction (dari internal) dan eksternal instructions (dari eksternal). Pembelajaran yang bersifat eksternal antara lain datang dari guru yang disebut teacing atau pengajaran. Dalam pembelajaran yang bersifat eksternal prinsip-prinsip belajar dengan sendirinya akan menjadi prinsipprinsip pembelajaran.

Pengertian ini menggambarkan bahwa Pembelajaran merupakan aspek kegiatan manusia yang kompleks yang tidak sepenuhnya dapat dijelaskan. Pembelajaran secara simpel dapar diartikan sebagai produk interaksi berkelanjutan antara pengembangan dan pengalaman hidup. Pembelajaran dalam makna kompleks adalah usaha sadar dari seorang guru untuk membelajarkan siswanya "mengarahkan interaksi siswa dengan sumber lainnya" dalam rangkan mencapai tujuan yang diharapkan.

Menurut Sanjaya (2011:13-14) Pembelajaran merupakan suatu sistem yang kompleks yang keberhasilannya dapat dilihat dari dua aspek yaitu aspek produk dan aspek proses. Keberhasilan pembelajaran dilihat dari sisi produk adalah keberhasilan siswa mengenai hasil yang diperoleh dengan mengabaikan proses pembelajaran. Hal ini menunjukkan bahwa dalam pembelajaran diharapkan siswa benar-benar merasakan manfaat pembelajaran itu setelah ia mempelajarinya.

Komalasari (2013:3) menambahkan bahwa Pembelajaran merupakan suatu sistem atau proses membelajarkan pembelajar yang direncanakan, dilaksanakan dan dievaluasi secara sistematis agar pembelajar dapat mencapai tujuan-tujuan pembelajaran secara efektif dan efesien. Pembelajaran 
merupakan sumber berupa visual maupun audiovisual yang dapat digunakan sebagai saluran alternatif pada komunikasi di dalam proses pembelajaran.

Berdasarkan kajian di atas, istilah pembelajaran yang digunakan dalam penelitian ini adalah suatu pembelajaran yang disusun secara sistematis yang digunakan guru dan siswa dalam pengajaran bahasa Indonesia di sekolah untuk mencapai tujuan yang diharapkan.

\section{METODE}

Setiap penelitian memiliki pendekatan yang berbeda-beda, bergantung pada metode yang digunakan masing-masing. Pendekatan yang digunakan dalam tulisan ini adalah penelitian kualitatif deskriptif. Penelitian kualitatif merupakan penelitian yang bermaksud untuk memahami fenomena tentang apa yang dialami oleh subjek penelitian, misalnya perilaku, persepsi, motivasi, tindakan, dan lainlain. Pendekatan penelitian kualitatif ditentukan oleh karakter penelitian kualitatif, yang tentu berbeda dengan karakter penelitian kuantitatif.

Dilihat dari ruang lingkupnya, penelitian kualitatif dibagi ke dalam dua cakupan, yakni penelitian kepustakaan (library research) dan penelitian lapangan (field research). Penelitian kepustakaan mengandalkan data-data yang hampir sepenuhnya dari perpustakaan, sehingga penelitian ini lebih populer dikenal dengan penelitian kualitatif deskriptif kepustakaan atau penelitian bibliografis. Selain itu, penelitian kepustakaan sering juga diistilahkan dengan penelitian non-reaktif, karena sepenuhnya hanya mengandalkan data-data yang bersifat teoritis dan dokumentasi yang ada di perpustakaan. Sementara itu, penelitian lapangan mengandalkan data-datanya di lapangan (social setting) yang diperoleh melalui informan dan data-data dokumentasi yang berkaitan dengan subjek penelitian.

Penelitian pustaka atau studi pustaka tidak hanya sekadar urusan membaca dan mencatat literatur atau buku-buku. Penelitian pustaka merupakan rangkaian kegiatan yang berkenaan dengan metode pengumpulan data pustaka, membaca dan mencatat serta mengolah bahan penelitian. Adapun dalam tulisan ini, jenis penelitian yang digunakan adalah penelitian kualitatif deskriptif kepustakaan atau penelitian bibliografis, karena mengandalkan teori-teori dari buku sebagai literatur.

\section{HASIL DAN PEMBAHASAN}

\section{A. Model Pembelajaran Bahasa Dan Sastra Indonesia yang ideal}

Ada beberapa aspek yang perlu diperhatikan dalam pembelajran bahasa dan sastra Indonesia yang ideal, yaitu : 
1) Konsep adalah suatu ide atau gagasan atau suatu pengertian yang umum, misalnya sumber kekayaan alam yang dapat diperbarui.

2) Prinsip adalah suatu kebenaran dasar sebagai titik tolak untuk berpikir atau merupakan suatu petunjuk untuk berbuat/melaksanakan sesuatu.

3) Fakta adalah sesuatu yang telah terjadi atau yang telah dikerjakan/dialami. Mungkin berupa hal, objek atau keadaan. Jadi bukan sesuatu yang diinginkan atau pendapat atau teori. Contoh : Proklamasi Kemerdekaan RI adalah pada tanggal 17 Agustus 1945.

4) Proses adalah serangkaian perubahan, gerakan-gerakan perkembangan. Suatu proses dapat terjadi secara sadar atau tidak disadari. Dapat juga merupakan cara melaksanakan kegiatan operasional (misalnya di pabrik) atau proses pembuatan tempe, proses peubahan warna pada daun yang kena hama wereng dan sebagainya.

5) Nilai adalah suatu pola, ukuran atau merupakan suatu tipe atau model. Umumnya nilai bertalian dengan pengakuan atau kebenaran yang bersifat umum, tentang baik atau buruk misalnya: hukum jual beli, hukum koperasi unit desa, Bimas dan sebagainya.

6) Keterampilan adalah kemampuan berbuat sesuatu dengan baik. Berbuat dapat berarti secara jasmaniah (menulis, berbicara dan sebagainya) dan dapat juga berarti rohaniah (membedakan, menganaliss dan sebagainya). Biasanya kedua aspek tersebut tidak terlepas satu sama lain, kendatipun tidak selalu demikian adanya. (Oemar Hamalik, 1978).

\section{B. Langkah-langkah Dalam Pembelajaran Yang Ideal}

Materi pembelajaran yang dipilih untuk diajarkan oleh guru dan harus dipelajari siswa hendaknya berisikan pembelajaran yang benar-benar menunjang tercapainya standar kompetensi dan kompetensi dasar. Secara garis besar langkah-langkah pembelajaran meliputi : (a) mengidentifikasi aspek-aspek yang terdapat dalam standar kompetensi dan kompetensi dasar yang menjadi acuan atau rujukan, (b) mengidentifikasi jenis-jenis materi pembelajaran, (c) memilih pembelajaran yang sesuai atau relevan dengan standar kompetensi dan kompetensi dasar yang telah teridentifikasi tadi., dan (d) memilih sumber pembelajaran.

Secara lengkap, langkah-langkah pembelajaran dapat dijelaskan sebagai berikut: 


\section{1) Mengidentifikasi aspek-aspek yang terdapat dalam standar kompetensi dan}

kompetensi dasar. Sebelum menentukan materi pembelajaran terlebih dahulu perlu diidentifikasi aspek-aspek standar kompetensi dan kompetensi dasar yang harus dipelajari atau dikuasai siswa. Aspek tersebut perlu ditentukan, karena setiap aspek standar kompetensi dan kompetensi dasar memerlukan jenis materi yang berbeda-beda dalam kegiatan pembelajaran. Sejalan dengan berbagai jenis aspek standar kompetensi, materi pembelajaran juga dapat dibedakan menjadi jenis materi aspek kognitif, afektif, dan psikomotorik. Materi pembelajaran aspek kognitif secara terperinci dapat dibagi menjadi empat jenis, yaitu: fakta, konsep, prinsip dan prosedur (Reigeluth, 1987). Materi jenis fakta adalah materi berupa nama-nama objek, nama tempat, nama orang, lambang, peristiwa sejarah, nama bagian atau komponen suatu benda, dan lain sebagainya. Materi konsep berupa pengertian, definisi, hakekat, inti isi. Materi jenis prinsip berupa dalil, rumus, postulat adagium, paradigma, teorema. Materi jenis prosedur berupa langkah-langkah mengerjakan sesuatu secara urut, misalnya langkah-langkah menelpon, cara-cara pembuatan telur asin atau cara-cara pembuatan bel listrik.Materi pembelajaran aspek afektif meliputi: pemberian respon, penerimaan (apresisasi), internalisasi, dan penilaian. Materi pembelajaran aspek motorik terdiri dari gerakan awal, semi rutin, dan rutin.

2) Memilih jenis materi yang sesuai dengan standar kompetensi dan kompetensi dasar. Materi yang akan diajarkan perlu diidentifikasi apakah termasuk jenis fakta, konsep, prinsip, prosedur, afektif, atau gabungan lebih daripada satu jenis materi. Dengan mengidentifikasi jenis-jenis materi yang akan diajarkan, maka guru akan mendapatkan kemudahan dalam cara mengajarkannya. Setelah jenis materi pembelajaran teridentifikasi, langkah berikutnya adalah memilih jenis materi tersebut yang sesuai dengan standar kompetensi atau kompetensi dasar yang harus dikuasai siswa. Identifikasi jenis materi pembelajaran juga penting untuk keperluan mengajarkannya. Sebab, setiap jenis materi pembelajaran memerlukan strategi pembelajaran atau metode, media, dan sistem evaluasi/penilaian yang berbeda-beda. Misalnya, metode mengajarkan materi fakta atau hafalan adalah dengan menggunakan “ jembatan keledai”, “ jembatan ingatan” (mnemonics), sedangkan metode untuk mengajarkan prosedur adalah " demonstrasi" . 


\section{3) Memilih sumber pembelajaran.}

Setelah jenias materi ditentukan langkah berikutnya adalah menentukan sumber pembelajaran. Materi pembelajaran dapat kita temukan dari berbagai sumber seperti buku pelajaran, majalah, jurnal, koran, internet, media audiovisual, dsb.

\section{E. PENUTUP}

\section{Simpulan}

Model pembelajaran adalah suatu rencana mengajar yang melibatkan pola pembelajaran tertentu. Dalam pola tersebut dapat terlihat kegiatan guru, siswa, sumber belajar yang digunakan di dalam mewujudkan kondisi belajar atau sistem lingkungan yang menyababkan terjadinya belajar pada siswa.

Pembelajaran merupakan kombinasi yang tertata meliputi segala unsur manusiawi, perlengkapan, fasilitas, prosedur yang saling mempengaruhi dalam mencapai tujuan dari pembelajaran. Beliau mengemukakan tiga rumusan yang dianggap penting tentang pembelajaran yaitu:

- Pembelajaran merupakan upaya dalam mengorganisasikan lingkungan pendidikan untuk menciptakan situasi dan kondisi belajar bagi siswa.

- Pembelajaran merupakan upaya penting dalam mempersiapkan siswa untuk menjadi warga masyarakat yang baik dan diharapkan.

- Pembelajaran merupakan proses dalam membantu siswa untuk menghadapi kehidupan atau terjun di lingkungan masyarakat.

Materi pembelajaran yang dipilih untuk diajarkan oleh guru dan harus dipelajari siswa hendaknya berisikan materi yang benar-benar menunjang tercapainya standar kompetensi dan kompetensi dasar.

Untuk menciptakan bahan ajar yang inovatif pendidik harus mengetahui tentang hal-hal yang dapat menunjang keberhasilan dalam proses belajar salah satunya yaitu mengetahui bahan ajar dan sumber belajar.

\section{DAFTAR PUSTAKA}

Arikunto, Suharsimi. 2010. Prosedur Penelitian Suatu Pendekatan Praktek. Jakarta: PT. Rineka Cipta. Ary, Donald., Jacobs, Luchy Cheser., \& Razavieh, Asghar. 2004. Pengantar Penelitian dalam Pendidikan. Terjemahan oleh Rurchan, Arief. 2007. 
Yogyakarta: Pustaka Pelajar. Djumingin, Sulastriningsih \& Syamsudduha. 2009. Perencanaan Pembelajaran Bahasa dan Sastra Indonesia. Makassar: Badan Penerbit UNM. Gintings, Abdorrakhman. 2008. Esensi Praktis Belajar dan Pembelajaran. Bandung: Humaniora. Hamalik, Oemar. 2010. Psikologi Belajar dan Mengajar. Bandung: Sinar Baru Algesindo. Iskandarwassid \& Dadang Sunendar. 2011. Strategi Pembelajaran Bahasa. Bandung: PT. Remaja Rosdakarya. Kunandar. 2011. Guru

Profesional: Implementasi Kurikulum Tingkat Satuan Pendidikan (KTSP) dan Sukses dalam Sertifikasi Guru. Jakarta: Rajawali Pers. Mulyasa, E. 2005. Menjadi Guru Profesional. Bandung: Remaja Rosdakarya. Musfah, Jejen. 2011. Peningkatan Kompetensi Guru: Melalui Pelatihan dan Sumber Belajar Teori dan Praktik. Jakarta: Kencana. Sanjaya, Wina. 2011. Strategi Pembelajaran Berorientasi Standar Proses Pendidikan. Jakarta: Kencana. Syaefudin, Udin. 2009. Inovasi Pendidikan. Bandung: Alfabeta.

Ghazali,A.Syakur.2010.Pembelajaran Keterampilan Berbahasa dengan Pendekatan Komutatif Interaktif. Bandung: PT.Refika Aditama.

Pranowo.2014.Teori Belajar Bahasa untuk Guru Bahasa dan Mahasiswa Jurusan Bahasa. Yogyakarta: Pustaka Belajar. 